\title{
Romanticismo y Revolución en Latinoamérica
}

\author{
Autores:
}

Christian Paúl Naranjo Navas I Alegría Cumandá Navas Labanda

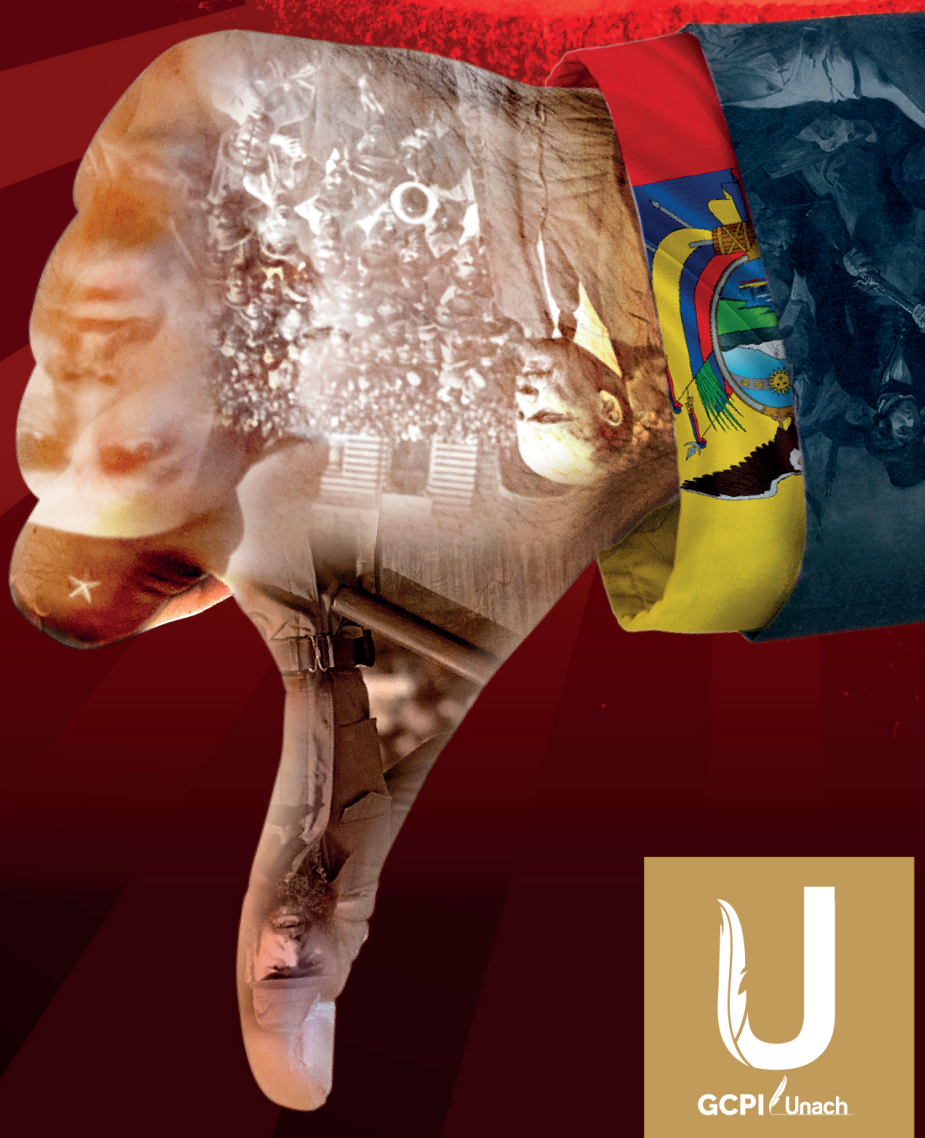





\section{Romanticismo y Revolución en Latinoamérica}

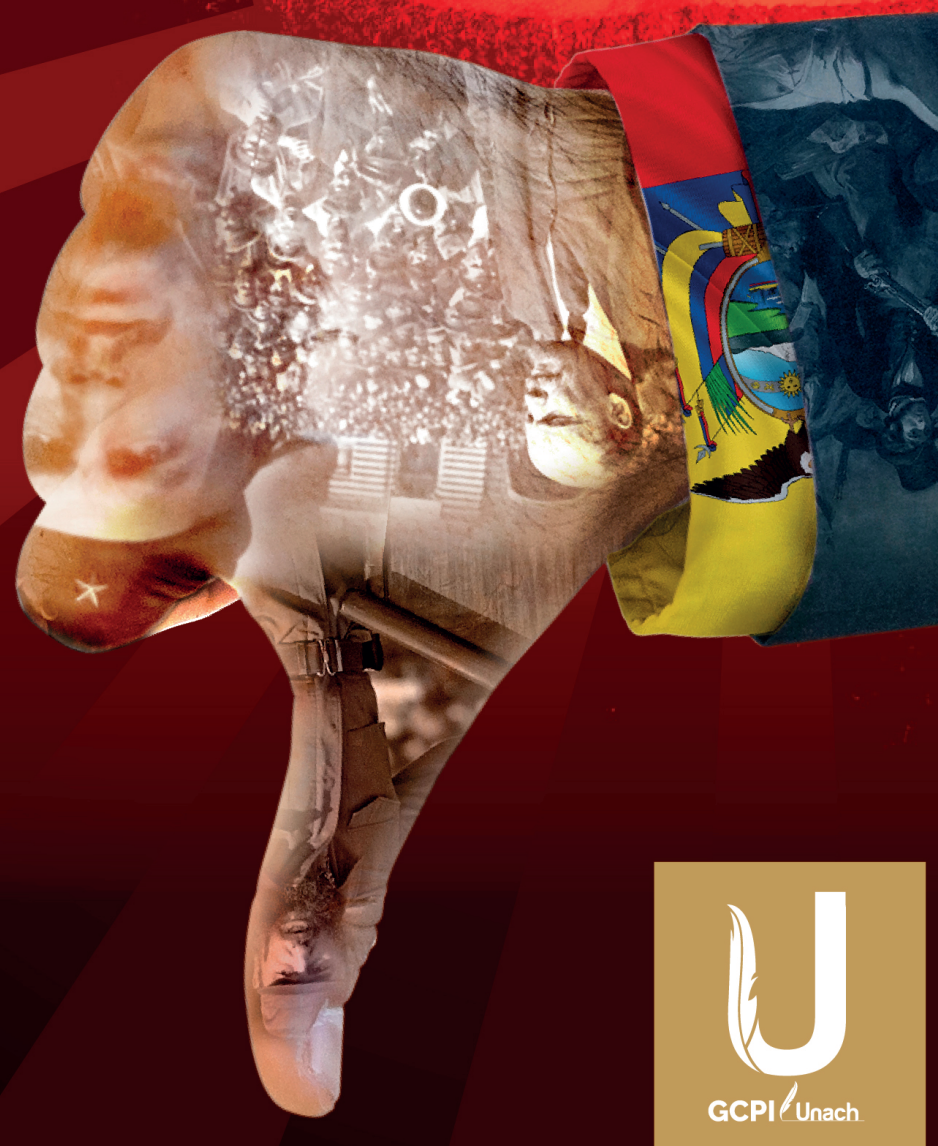




\section{UNIVERSIDAD NACIONAL DE CHIMBORAZO}

\section{Rector}

Ph.D. Gonzalo Nicolay Samaniego Erazo

Vicerrectora Académica

Ph.D. Ángela Calderón Tobar

Vicerrector de Investigación, Vinculación y Posgrado

Ph.D. Lexinton Cepeda Astudillo

Vicerrectora Administrativa

Ph.D. Anita Ríos Rivera

\section{Comité Editorial:}

Presidente: Ph.D. Lexinton Cepeda Astudillo

Secretaria: Ing. Sandra Zúñiga Donoso

Miembros: Ph.D. Margarita Pomboza Floril; Ph.D. Gerardo Nieves Loja; Ph.D. Carmen Varguillas Carmona; Ph.D. Cristhy Jiménez Granizo; Ph.D. Víctor Julio García; Msc. Clara Mayorga Mazón; Ph.D. Diego Pinilla Rodríguez.

Título de la obra: $\quad$ ROMANTICISMO $\quad Y \quad$ REVOLUCIÓN $\quad$ EN LATINOAMÉRICA

Nombres de los autores: Christian Paúl Naranjo Navas; Alegría Cumandá Navas Labanda; Riobamba, 2020

(C) UNACH, 2020

Ediciones: Universidad Nacional de Chimborazo (UNACH)

Diseño Gráfico: UNACH

Primera edición - Septiembre 2020

Riobamba - Ecuador

Se prohíbe la reproducción total o parcial de esta obra, sea cual fuere el medio, sin la autorizacion de los autor, por escrito del titular de los derechos.

ISBN: 978-9942-835-23-9

ISBN: 978-9942-835-24-6 (DIGITAL)

Registro Biblioteca Nacional

Depósito legal: 059029

DOI: https: / / doi.org/10.37135/u.editorial.05.04

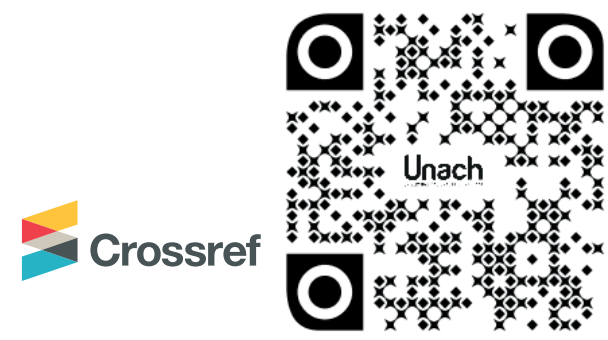




\section{Romanticismo y Revolución en Latinoamérica}

Autores:

Christian Paúl Naranjo Navas

Alegría Cumandá Navas Labanda

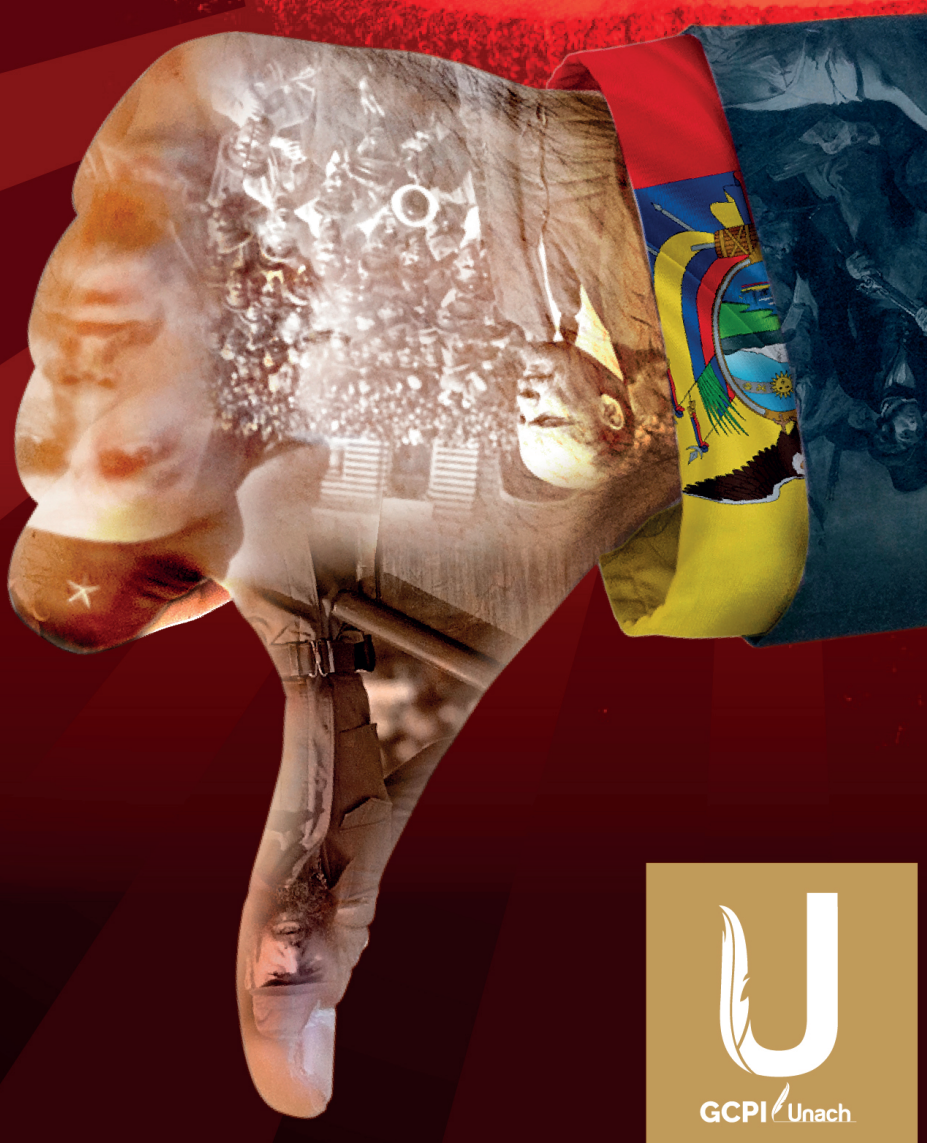





\section{Índice}

Contenido

Página

Introducción.

Capítulo 1.

Seducción y Revolución Discursiva 15

Capítulo 2.

Arte y Revolución. 36

Capítulo 3.

El Imperio y la Culpa 51

Capítulo 4.

Conciencia Colectiva

Capítulo 5.

Seguridad Regional 81

Capítulo 6.

Doctrinas Regionales 99

Conclusiones 115

Referencias 121 



\section{Introducción}

América Latina ha vivido procesos políticos intricados entre la influencia de occidente, con su pasión que abraza el liberalismo y protege a su hija predilecta, la democracia, y la influencia de las ideas de revolución emergentes desde el dominio marxista. Esta puja por una región inestable se encarna a partir del nacimiento de las repúblicas latinoamericanas en dos clanes: por un lado, un gran líder mundial, el hegemón, el llamado a personificar las estructuras de moralidad vista desde el orden y la reprensión; por otro lado, los movimientos revolucionarios que encarnan la sublevación a las ideas de occidente, la insurrección al capitalismo y el liberalismo, y a favor de la imposición de sistemas políticos que rayan con el marxismo: la eliminación de clases sociales, de la propiedad privada, de la libertad de prensa y opinión. Por un lado, en el contexto de occidente, el individuo sobresale sobre el comunitarismo y corporativismo; por otro lado, la idea de colectivo, representado en un gobierno, sobrepasa al individuo y a sus derechos.

Durante el reinado de Luis XIV (1643-1715), Francia se hallaba bajo el dominio de una monarquía absolutista, el poder del rey y de la nobleza eran la base de este régimen. El Estado se encontraba en una situación económica bastante precaria, que se agravó por el mal gobierno de Luis XV (bisnieto de Luis XIV), y tocó fondo durante el reinado de Luis XVI, gobernante bien intencionado, pero de carácter débil, por lo que se lo llamaba el buen Luis. Las crisis de las monarquías francesas condujeron la nación a la Revolución francesa, guiada por tres principios: libertad, igualdad y fraternidad. El ejemplo francés pretendería afirmar que la libertad es la piedra angular de toda revolución, pero la historia nos deja saber que la libertad, a veces, es aparejada con el capitalismo y, en su defecto, con la democracia. Las crisis han llevado a las naciones en pensar en subversiones que cambien el sistemas político, económico y social, pero la subversión no necesariamente comprende la inclusión de la libertad como eje conductor, sino que puede incluir la eliminación 
de la libertad y su reemplazo por la fidelidad al revolucionario y a sus ideales.

Es innegable la relación religiosa entre el revolucionario y el mesías, como entre la revolución y la salvación, como entre el comunismo y el paraíso. Sin embargo, la distinción es muy clara, el materialismo no contempla la idea de un salvador espiritual, sino que la salvación es terrenal y el salvador es un revolucionario que está dispuesto a matar y a morir. La divinidad se erige en un discurso, pero se consuma en la sedición: la muerte levanta al revolucionario como mesías, mientras que, permanecer con vida, en el tiempo, pinta al revolucionario como un ilusorio visionario. Lleva demasiado tiempo comprender que las ideas de revolución se embellecen en el imaginario colectivo, pero que en la práctica son crueles, sangrientas, despiadadas y arrogantes: las ideas de revolución pertenecen a la ilusión de una isla utópica, el lugar donde Tomás Moro construyó como la aproximación al edén.

El romanticismo de las ideas de revolución atrae las masas en una suerte de conjuro colectivo porque, al parecer, la prosperidad nunca será suficiente evidencia de progreso, como la modernidad nunca será lo suficientemente moderna, el capitalismo nunca traerá el suficiente bienestar, la democracia nunca producirá la suficiente representatividad, así como la espiritualidad nunca será lo suficientemente terrenal. Las ideas de revolución en América Latina pretenden dar respuesta a las insuficiencias del sistema a través de un único camino, la lucha de clases, creando simultáneamente una esfera de autoridad moral que juzgue con severidad las inopias creadas por el sistema, y que condene a quienes creen que la revolución cae en la misma categoría. El romanticismo recoge la idea de mesías, pero, al mismo tiempo, involucra el castigo a la contra revolución: la necesidad de eliminación del mal es parte de las responsabilidades del revolucionario.

La idea de moralidad, dentro de la revolución, recoge un principio primario, la lealtad al líder, la sumisión a la voz y mando del 
revolucionario, la aceptación de sus decretos sin cuestionamientos y sin murmullos. Desde la lealtad, cualquier acción es justificada, de hecho, incluso las actuaciones que protejan al mesías pueden ser premiadas. La fidelidad se juzga y mide con la misma vara, los seguidores son fieles en tanto y cuanto estén dispuestos a defender la honra del mesías, y son frágiles en su fidelidad en tanto y cuanto se presten a cuestionar sus decretos. Así, la valía o benevolencia de la verdad, el amor, la misericordia, la vida y la honradez quedan relegadas a la fidelidad. La moralidad depende de un principio primario, la voluntad de sumisión completa al mesías. La revivificación del mesías se trama en la correspondencia entre la ingenuidad y la necesidad: aldeas que han sido persuadidas en la mutación súbita de su contexto a través de un mesías, una suerte de ungido divino, quien permutará los contextos manejados por el imperialismo.

De la misma forma, las ideas de revolución intentan construir la legalidad como una respuesta a la fidelidad hacia sí misma, la fidelidad hacia el enviado por el destino. En este contexto, los derechos son derechos en tanto y cuanto no cuestionen los motivos del mesías, ni los motivos de su movimiento. Por otro lado, los deberes son claros, la defensa legal de la honra, sabiduría y coraje del mesías, y, si este ha muerto, la defensa de su imagen, la continua celebración de honra como salvador divino, y el constante recordatorio de su función como fundador de una nueva patria. La legalidad se construye alrededor de la revolución, y debe castigar cualquier intento de construirla alrededor de otros principios, ideas o marcos contextuales.

La educación también cae en las redes de la lealtad pues el adoctrinamiento de la población es esencial para mantener viva la revolución. Los cuestionamientos debilitan el sistema de legalidad pues se dedicaría, principalmente, a la persecución a los detractores de la revolución. Como no es conveniente el uso indiscriminado de recursos en el juzgamiento de la infidelidad, el adoctrinamiento escolar es indispensable. La historia empieza a contarse desde un 
solo marco teórico, el triunfo de la revolución: la historia oficial se empieza a enseñar en escuelas y colegios, cualquier otra versión es cuento organizado por el imperialismo, por la burguesía o por el sistema capitalista que gobierna el mundo.

El corporativismo funciona en la moralidad, en la legalidad, en el sistema educativo, en los medios de comunicación y en el sistema político, dejando pocos espacios para el ejercicio libre de la comunicación, para el quehacer libre de pensadores, escritores, académicos, en general, dejando pocos espacios para la crítica, necesaria para el desarrollo de las sociedades. La libre opinión se convierte en una amenaza para el corporativismo, al mismo tiempo, el castigo surge como la herramienta más útil para desprestigiar o acallar la libertad de expresión: la libertad emerge como el absoluto enemigo del espíritu corporativista, la opinión se erige como el estandarte de un enemigo que rehúsa la muerte, que desecha la lealtad como principio primario de una nueva moralidad. La única opción para el espíritu corporativista es desaparecer al enemigo, haciendo uso de todo tipo de represión porque, al fin y al cabo, todo es justificado en tanto y cuanto la lealtad sobresalga como eje catequista.

Aristóteles describía dos tipos de revoluciones políticas, a saber: cambio completo desde una constitución a otra; y, modificación desde una constitución existente. Las dos opciones son posibles, no obstante, el patrón en América Latina se moviliza en dos olas: una primera ola caracterizada por los movimientos revolucionarios armados que, en el tiempo, se convirtieron en guerrillas y otros en narco-guerrillas; una segunda ola en la cual las ideas de revolución hicieron uso de los sistemas democráticos, llegando a puestos políticos a través de las elecciones $\mathrm{y}$, una vez en el poder, realizaron los cambios estructurales (constitucionales) necesarios. En este último caso, cada decisión política se justificaría en las elecciones de las masas, cada atropello, persecución o denostación lo haría con una apología fundamentada en las elecciones. En ambos casos, cuando el mesías llega al poder, la dictadura del proletariado se 
encarniza y la alternancia se esfuma rápidamente porque, como en cualquier autocracia, los dictadores no desean dejar el poder, sino, por el contrario, creen que ellos son el poder, ellos son la política, sin ellos, la ilusión de revolución desaparece: no hay revolución sin mesías, como no hay transición al comunismo sin la dictadura del proletariado.

La conceptualización de la revolución conlleva al análisis de cambios estructurales, cambios que conmuevan los fundamentos de las sociedades. No obstante, el relleno del concepto queda sumergido en variaciones ideológicas. Por un lado, nos llevamos la ilusión de una revolución liberal, recordando los ideales de la Revolución francesa o de la Revolución americana. Por otro lado, la revolución del proletariado nos conduce a la utopía del comunismo, atisbada en la Revolución rusa, o en la Revolución cubana. El siglo XX muestra una América Latina ensimismada por la segunda opción, una idea de revolución que se comporta con la guía de ciertos ideales marxistas. El lenguaje del marxismo es casi inevitable en los movimientos subversivos de la región: la idea de revolucionario, del proletariado, del burgués, y del imperio se impusieron sobre el lenguaje atiborrado de vocablos como democracias, estado de derecho o división de poderes. La realidad se redujo a una principal causa de la desigualdad y miseria de los pueblos, la existencia de clases: la única opción, la lucha de clases que nos llevaría al fin de la historia, a una sociedad comunista.

El libro comienza indagando las ideas de revolución desde varias aristas, ¿a qué llamamos revolución? El deseo de revolución se ve como un elemento intrínsecamente suelto en el ser humano, $\mathrm{y}$, sin embargo, un elemento que revive de época en época en una región que se mueve entre blancos y negros, entre opuestos, intentando dar respuesta a la ilusión que existe, un cambio que lleve a nuestras naciones al fin de la historia, al destino preparado, el engrandecimiento de América Latina. Las ideas de revolución en la región latinoamericana han pretendido movilizarse entre los deseos de firmeza, igualdad y comunidad, abriendo el espacio 
para la opresión de quien no esté de acuerdo con estos deseos. La revolución atrae una ilusión que invade los deseos más íntimos pero que, en el tiempo, carcome la esperanza: el mesías nunca llegará a ser mesías, el paraíso jamás llegará a ser paraíso. Así, en el tiempo, el mesías se convertirá en un farsante, un profeta que merece ser sentenciado como falso, un ángel caído y convertido en demonio. Este escrito revisa las ideas esenciales alrededor de la conceptualización de revolución en América Latina, tomando en cuenta los íconos históricos que dieron forma a la discursiva y retórica de los movimientos subversivos. El análisis de las ideas que se movilizan alrededor de la revolución llevará al lector a considerar nuevos marcos conceptuales dentro de las ciencias políticas, de las relaciones internacionales, del psicoanálisis, y de la filosofía. 


\section{Capítulo 1.}

\section{Seducción y Revolución Discursiva}


Cierta historia latinoamericana se ha visto escrita y reescrita a través de enfoques ideológicos que comprometen el resurgimiento del espíritu revolucionario, en una suerte de eterno retorno, el cual tiene la complicidad de la espera: el mesías revolucionario vendrá para salvar a la región de la pobreza, de la miseria, del capitalismo. Los pueblos lo esperan, las masas lo aclaman, el proletariado ha predicado sobre su regreso, sobre su venida e imposición de su reino terrenal. Para esta versión de la región, el espíritu del salvador despierta de vez en vez, como una respuesta al embate capitalista, como una respuesta al impulso del individuo sobre el colectivo, como una respuesta al liberalismo. Las singularidades de las ideas de revolución contemplan también el resurgimiento del imperio, de la burguesía, de la prosperidad capitalista: la idea de la luz, encarnada en el mesías, es impensable sin la idea de la penumbra, la cual cobija al imperio y a todos sus similares.

En la vida, muerte y resurrección de las ideas de revolución en América Latina, los fantasmas del capitalismo no desaparecen por dos razones subrepticias en la historia de la región. Primera, la necesidad de la idea del enemigo, de la justificación, del anticristo engendrado en un gobierno o imperio, la necesidad del leviatán encarnado en los burgueses o empresarios, en periodistas o anti patrias; la idea del opuesto es indispensable porque la luz no puede ser luz sin la oscuridad, el bien no puede ser benevolente sin la maldad, así, la revolución no puede ser exitosa sin el statu quo, sin la idea del capitalismo, sin la idea de la burguesía. Segunda, la posibilidad de error o fracaso requiere de un chivo expiatorio: el fracaso nunca será culpa de la revolución, de sus líderes, o del intento de fundar o refundar todo lo existente, la culpa siempre la tendrá el imperio, la burguesía, los empresarios, los periodistas, etc. La idea de revolución no puede ser ensuciada porque el aura de divinidad que la acompaña no abre espacio para ningún tipo de mácula. Si la revolución fracasa, el leviatán tendrá la culpa, si la revolución erra, será a causa del imperio, si la revolución no produce las promesas ofrecidas, tendrá al despiadado capitalismo para acusarlo por sus interminables tentáculos de dominación. 
El romanticismo, que se genera como aurora alrededor de las ideas de revolución, se manifestaría durante el siglo XX en sentimientos de odio, agresividad, y rebeldía. Los sentimientos en contra del capitalismo, del imperio, la burguesía, y demás, florecieron en una suerte de reverbero que se va acumulando en el tiempo, en espera del momento adecuado para rebosar, salpicar y quemar a todo lo que se encuentra alrededor. Empero, estos sentimientos no surgieron sin causa o en la azarosa confusión de ideologías, sino, por lo contrario, surgieron como respuesta a las intervenciones despiadadas, a las intromisiones evidentes, y a las doctrinas regionales que se pensaron dentro de los hemisferios del Hegemón, doctrinas de las cuales nunca fuimos consultados o asesorados, sino que nos vimos envueltos en ellas en el transcurso de la historia. Sin opción a la respuesta eficiente, y sin opción a la divergencia (porque nos convenía estar aliados al líder mundial), las ideas de revolución se vigorizaron cuando hallaron intuitivamente el delta retórico apropiado: el infortunio, la penuria y la arbitrariedad en una punta; la necesidad de degollar a los que son y a los que parecen culpables, a los capitalistas, pero también a los anti revolucionarios, en una segunda punta; $y$, finalmente, en el último vértice, la manifestación del mesías, el insurrecto, el aclamado, el elegido por el destino, quien se hará responsable del encargo de aniquilar el mal, de desaparecer al enemigo, de barrer con cualquier sombra de capitalismo.

La segunda mitad del siglo XX representa la versión armada del choque ideológico entre la dicción capitalista del desarrollo, y la dicción revolucionaria del marxismo. En este empantanado choque discursivo, la Guerra Fría proveería de un espacio argumentativo que representaría una desenfrenada competencia en las áreas tecnológicas, económicas y políticas. Este espacio ideológico traería a su representante predilecto, la retórica. Así, las ideas de revolución encontrarían la forma adecuada de representar sus sentimientos, y la forma adecuada de mover las masas en una suerte de justificación o de apoyo ciudadano. La retórica de la revolución se convertiría en el discurso altisonante, lleno de variaciones lingüísticas que llegarían a un mismo objetivo: la aclamación del mesías, y la urgente justificación de sus actos en el intento de destrucción de la maldad: el mesías viene a destruir la maldad y a salvar al proletariado. 
A partir de la Guerra Fría, la conceptualización de esta destreza seductiva colmaría los discursos de las ideas contemporáneas de revolución en América Latina. Esta táctica se convierte en una muletilla indispensable en la relación de poder entre mesías, proletariado y burguesía, se convierte en una técnica de uso habitual en cualquier tendencia que intente fundar y refundar la nación, que intente cambiar principios y remover costumbres, o que intente eliminar el statu quo en favor de otro. En toda idea revolucionaria, la organización seductiva es similar: "en cada historia hay un héroe, un crimen, una víctima, y un villano. En la historia de defensa personal, el héroe y el villano son los mismos. En ambas historias, el villano es inherentemente malo e irracional: el héroe no puede razonar con el villano; tiene que luchar y derrotarlo o matarlo. En ambos casos, la víctima debe ser inocente y que sobrepase cualquier reproche" ${ }^{\prime 1}$.

Los discursos de la revolución se plantean, entonces, dentro de un triángulo argumentativo, por medio del cual, cualquier versión de la realidad se reduce, y por medio del cual, el romanticismo puede producir efectos prácticos en una población esperanzada en el cambio. La relación discursiva entre la víctima, el villano y el héroe hace uso de la retórica para la generación de los efectos sensibles de toda revolución. Estas muletillas convienen con la retórica de la revolución a partir del legado de un espacio ideal, entendido a través de la lucha de clases: un orden de reflexión asimilado en el modo y visión marxista de la realidad, la lucha de clases demanda una horma teórica concreta y conjetura concebirla dentro de los supuestos básicos del marxismo ${ }^{2}$. Es indudable que la corriente marxista ha influido la región latinoamericana de forma profunda, tanto que ninguna revolución es pensada por fuera del espectro marxista, o del espectro de su lenguaje, todo discurso revolucionario juega con la horma de la lucha de clases, del fin de la historia y del ideal de una sociedad igualitaria. El pensamiento marxista ha servido como

1 LAKOFF, George. Don't think of an elephant!. White River Junction: Chelsea Green Pub. Co, 2004, p. 71. ISBN: 1-931498-71-7. Traducción hecha por el autor.

2 VIGUERA, Aníbal. Movimientos Sociales y Lucha de Clases. Conflicto Social, 2009, vol 2, no. 1, p. 7. ISSN: 1852-2262. 
fundamento retórico para los movimientos sociales y políticos que pulularon la región durante la segunda mitad del siglo $\mathrm{XX}, \mathrm{y}$ ha servido como fundamento para la generación de clichés culturales que mezclan el marxismo con el cristianismo, la sabiduría ancestral y la post verdad: la irracionalidad de este farrago no es asunto de la revolución, lo importante es el impacto social, la asimilación y la movilización de apoyo masivo. Es un riesgo innegable el intento de entender los movimientos revolucionarios de la región por fuera de la estructura ideológica marxista, o por fuera de la estructura dialéctica utilizada en las herramientas discursivas.

La organización argumentativa de Lakoff $^{3}$ tiene aproximaciones útiles para el entender las herramientas discursivas en los movimientos revolucionarios. La organización argumentativa hace uso del lenguaje marxista. De hecho, el marxismo provee de "un punto de vista filosófica de al menos una tercera parte de la población mundial en la segunda mitad del siglo XX"4. La imagen de conflicto entre clases, de la lucha de clases propuesta por Marx, y anteriormente por Saint-Simon, encontró sus fundamentos en el proceso dialéctico-histórico esbozado por Hegel, la fuerza de las ideas dentro de la historia confluye en la generación de una nueva idea, o la primacía de un ideal que prevalece en el tiempo: tesis y antítesis se confrontan para provocar una nueva idea, o para suponer la preeminencia de una idea sobre la otra, la síntesis. Dentro del pensamiento marxista, la lucha entre clases promovería la dictadura del proletariado y, ulteriormente, una nación comunista. El molde de la visión marxista se utilizaría para pensar en la sociedad, para razonar sobre los movimientos históricos, y para proponer el cambio de rumbo a través de la revolución. El modelo de visión marxista se utilizaría como modelo discursivo, estructurándolo como un estándar dentro del cual los movimientos revolucionarios podrían armar y desarmar sus argumentos.

3 LAKOFF, George. Op.Cit. 2004.

4 STUMPF, Samuel y FIESER, James. Philosophy History and Problems. 6 a ed. New York: McGraw-Hill, 2003, p. 363. ISBN: 0-07-240635-6. Traducción hecha por el autor. 
El modelo discursivo que propone Lakoff ${ }^{5}$ se adapta a la visión marxista del capitalismo: estas formas se sumergen en una sola forma retórica que caracteriza las ideas y movimientos revolucionarios. Sea intuitivamente, o por aprendizaje, el modelo discursivo termina siendo muy similar: la presencia del mártir, el opresor y el héroe, dentro del lenguaje utilizado por Lakoff; el proletariado, la burguesía y el revolucionario, dentro del lenguaje marxista. Sin embargo, la diferencia más importante recae en el impacto y trascendencia de los moldes discursivos: para Lakoff, el molde retórico es utilizado como un método de discusión, de argumentación, como parte de las herramientas extendidas dentro de los debates; para Marx, el modelo discursivo procura concebir el espacio político dentro de un juego de poder entre el proletariado y la burguesía: el choque de clases que daría fruto a la sociedad comunista. Este espacio político, dentro del cual surge la contraposición de fuerzas, daría paso a la sociedad caracterizada como ideal dentro del imaginario del fin de la historia, una sociedad en la cual las clases sociales han desaparecido, y en la cual las diferencias han sucumbido a la idea de igualdad. En la práctica, los moldes retóricos de Lakoff y del marxismo se entremezclan y no delinean diferencias, en la práctica, todo argumento se adapta a la visión discursiva, y toda visión de la realidad se amolda a la relación entre el mesías, el pueblo y la burguesía.

La estructura discursiva, derivado del enfoque de la realidad del marxismo, y derivado de la horma argumentativa explicada por Lakoff, reduce la complejidad del quehacer político a la imposición, a la agresión, a la visualización de la única vía para la prosperidad de la revolución, el conflicto. El conflicto se convierte en la única vía posible para la eliminación del mal, y la buena ventura del proletariado: sin conflicto, la revolución no es revolución. Esta forma de argumentación propuso un solo camino, la violencia, y, si era necesario, el asesinato de todo aquel que era considerado antirrevolucionario, antipatria, o amigo del imperio. La justificación de la violencia trajo consigo, entonces, la justificación del asesinato y, por ende, la justificación de la opresión. La visión

LAKOFF, George. Don't think... Op. Cit. 
reducida del discurso revolucionario llevó a las corrientes políticas afines a justificar el crimen como una de las pujanzas vibrantes de la historia. De hecho, por mucho tiempo, no se daba ponderar alguna idea de revolución sin advertirse acicalado como civil, con un fusil que colgaba de la espalda, con una barbilla tupida y con un puro entre comido que guindaba de los labios. Este retrato se conjuraba con el concepto de justicia: era el revolucionario, el que cargaba el fusil, el que no tenía miedo a disparar, ni miedo a morir, el justiciero del pueblo, con el coraje inmutable y con una estructura de moralidad de un solo principio, desterrar o desaparecer al enemigo de la revolución, al villano encarnado en la burguesía o en el imperio. La necesidad de causar la confrontación a través del resurgimiento del espíritu revolucionar, vio su movilización en dos calzadas: primera, en el arma guindando del hombro, a la espera de ser utilizada o a la espera de convertirse en la herramienta de la justicia, apuntando directamente a los convictos, aquellos enemigos de la revolución; segunda, a través de procesos que se revistan de cierta imagen de democracia, de cierta imagen de libertad, con el objetivo de alcanzar el poder por medio del voto $\mathrm{y}$, una vez en el poder, realizar los cambios estructurales con la justificación del apoyo electoral del pueblo. El primero camino fue una constante para la región latinoamericana durante todo el siglo XX; el segundo camino, una alternativa elegida por los movimientos socialistas del siglo XXI que llegaron al poder mediante las elecciones populares.

Toda idea revolucionaria, encarnada en un movimiento político o social, se reviste de un aura común, la idea de que después de la revolución, no hay nada posible, después de la revolución, no hay espacio para el retorno o la desviación, después de la revolución, la historia ha llegado a su fin. El fin de la historia puede ser descubierto, sea bien con un fusil colgando de los hombros del revolucionario, o a través de términos electivos que prometan un manto de legalidad demócrata. Las doctrinas de revolución diseminaron simientes en letrados y políticos, en vocablos de Josué de Castro, sociólogo brasileño: "Yo, que he recibido un premio internacional de la paz, pienso que, infelizmente, no hay otra solución que la violencia 
para América Latina" ${ }^{\prime}$. Durante el siglo XX, se creía que la vía más fácil de la revolución era la intimidación, mientras los espíritus de la sublevación se materializaban en alocuciones apasionadas, las cuales estaba llenas de historietas, poemarios y peroratas dedicadas a la segunda emancipación de América Latina. Sin embargo, el fin de la historia produce un problema de contradicción: la idea del fin de la historia conlleva la proclamación de una especie de destino, dentro de la cual, aún la libertad debe sometérsela: el determinismo de la revolución crea, entonces, una paradoja insondable: por un lado, la necesidad de provocar la rebelión, de provocar el choque de clases; por otro lado, la idea de fin de la historia requiere de un fundamento manifiesto, el destino. A decir, por un lado, si existe esta suerte de destino manifiesto, no sería, entonces, necesaria la revolución, porque esta ocurriría inexorablemente; por otro lado, si la revolución es necesaria, y debe ser provocada, entonces, la idea del destino manifiesto se diluye porque requiere de la acción libre y voluntaria de los revolucionarios para crear el conflicto social. De esta forma, la idea del fin de la historia recae necesariamente en una paradoja, o, más explícitamente, en una contradicción.

La conciencia de la revolución permanece en el tiempo, se permute en cada generación, vive, muere y resucita de acuerdo a los ciclos del capitalismo: en tanto y cuanto la prosperidad colme la sociedad, la revolución permanece quieta, dormida, a la espera de revelarse; cuando los ciclos de contracción aparecen, entonces, la conciencia revolucionaria muestra su vibrante faceta, se permuta y revive en una suerte de respuesta a la contracción, como una vía para la salvación. La conciencia colectiva de la revolución se mueve orbicularmente, como en una especie de eterno retorno, y se nutre de la animadversión frente a la maldad encarnada en el capitalismo. El hedor de la maldad vendría a ser percibido durante el siglo XX, y se enfatizaría con la entremezcla de términos nuevos y usados por décadas, el discurso de la neo colonización se alimentaría con el concepto de la vieja usanza, de la comarca, como una forma de nutrir la animosidad del proletariado. Esta comarca, "se especializó en perder desde los remotos tiempos en que los europeos del

6 GALEANO, Eduardo. Las venas abiertas de América Latina. Siglo XXI, 2004, p. 5. 
Renacimiento se abalanzaron a través del mar y le hundieron los dientes en la garganta"7. La conciencia revolucionaria aparece de vez en vez, y desaparece una vez que el fin de la historia no llega, cuando la concepción socialista nunca aterriza. Entonces, su aparición obedece a un deseo de respuesta, y su desaparición es evidente cuando las promesas ofrecidas se quedan en el espacio de la quimera.

Las ideas revolucionarias en América Latina se sustentan y reviven con el acento sobre la creación de la miseria y la ambición de permutación. La revolución revive en cada contracción del sistema, y se multiplica ferozmente mediante la creación de un sentimiento de cercano al odio, a la envidia, al rencor. Se construye, entonces, la noción de miseria gracias a la necesidad de apuntar el dedo al culpable, y por medio de métodos sociales o históricos que procuran repasar la historia desde la visión discursiva de la imposición, desde la idea de la imposición de la modernidad, del bienestar liberal, de la imposición de los sistemas democráticos occidentales. Con la declaración del culpable, el revolucionario se convierte en el mesías, profetizado por la comuna, quien vendría ofrecer su vida por el proletariado, mientras, al mismo tiempo, destruiría la maldad. En este intento, el iluminado no puede ser contradicho o negado, el mesías no tiene errores, y toda mancha es justificable, todo atropello es menospreciado, todo autoritarismo es necesario para el objetivo primario, la destrucción de la maldad. El relato de la imposición constituye en sí misma el reflejo del villano, y, del villano, no debe quedar ni su sombra.

La imagen de villano evoca inevitablemente la idea del mesías: el uno no puede existir sin el otro, la dualidad del discurso no es funcional si la idea de mal no existe, porque se requiere del pecado original, acumulado y esparcido en la sociedad a través del capitalismo, para dar cabida a la idea del mesías. Sin la idea de capitalismo, no es posible la idea de revolución, si la idea del villano, no hay cabida para la idea del revolucionario. La presencia 
del infame sistema de opresión es imposible sin la coexistencia del elegido en la historia de la lucha de clases, del mesías, alguien que proceda del proletariado, que esté dispuesto a matar y a morir, o que aparente estar dispuesto, la realidad, en este punto, no importa, solo el discurso. Una persona con la apariencia de un ente espiritual, con la apariencia de un ser cercano a lo trascendente, cercano a la espiritualidad comunitaria, alguien que ha dejado de lado la tradición católica, o la utiliza de forma discursiva para mezclarla con el espacio de una espiritualidad endógena, como que el catolicismo y la pacha mama fueran iguales, congruentes, y complementarios. El mesías recrea una esfera inmaculada en torno de lo que se conoce como ancestral, en torno de la pacha mama, de la chacana, pero también en torno del obispado, de los líderes comunitarios de la iglesia: el mesías saber conjurar discursivamente lo autóctono con lo occidental, siempre y cuando no se entrometan con el objetivo primario.

Sin embargo, como un juego tautológico que se difumina en el accionar discursivo, el mesías igualmente despierta la noción del villano, de los culpables, de aquellos que colonizaron la región latinoamericana, de aquellos que la atracaron y la hundieron paulatinamente. Los culpables se relacionan estrechamente con el hegemón, aquellos quienes en algún momento nos pensaron como parte de su "patio trasero". Se ha erigido el imaginario de la idea del hegemón dentro de connotaciones de usufructo, crueldad y corrupción: dentro de la discursiva revolucionaria, las desventuras de Latinoamérica fueron causadas por la opresión de la colonia y el imperio. La identificación del culpable, real o ficticio, apela al resentimiento, ávido de venganza, hambriento de violencia. Sin embargo, en la práctica, el culpable, el villano, puede encarnarse en todo lo que se oponga a la revolución. El villano contrae el espectro a una sola vía: su eliminación, cualquier negociación o pacto aparente solo puede ser temporal, solo puede ser momentáneo, porque el objetivo primario del mesías es destruir la maldad encarnada en el enemigo. No obstante, esta discursiva entra en una paradoja, si la maldad desaparece, también lo hace la necesidad de la revolución, $\mathrm{y}$, dentro del espectro conceptual, llegaríamos al fin de la historia; 
empero, como el fin de la historia es parte del espacio imaginario y utópico, la revolución no desaparecerá y, por ende, tampoco lo hará la maldad. Entonces, aunque el objetivo del mesías sea la eliminación del mal, no podrá realizarlo porque, al mismo tiempo, significaría la eliminación de la revolución.

Uno de los entes ambiguos, no comprensibles a primera mano, no identificados a priori a favor, es la iglesia. La relación con la iglesia contrae suspicacias que no pueden ser saldadas inmediatamente. La revolución requiere revisar la posición institucional para tomar distancias o para acercarse como aliado. A veces, la opinión de la institución difería de la opinión de los clérigos insertados en las comunidades. A veces, los clérigos crearían teorías políticas que las llamaría teológicas, y crearían doctrinas que las ajustarían a la visión comunitaria del momento. La iglesia serviría como compañera siempre y cuando estuviese abierta a apoyar al mesías: siempre y cuando la teología se adecue y forje conceptual y prácticamente su apoyo, la iglesia es bienvenida; siempre y cuando se justifique las maquinaciones de la revolución, el santuario eclesiástico se convertiría es un socio indefectible. De esta forma, "la revolución era la forma de lograr un gobierno que dé de comer al hambriento, que, vista al desnudo, que enseñe al que no sabe, que cumpla con las obras de caridad, de amor al prójimo no solo en forma ocasional y transitoria, no solo para unos pocos, sino para la mayoría de nuestros prójimos" $^{8}$. La teología de la liberación retomaría la influencia de la institución, pero esta vez no partiría de una plataforma espiritual, sino desde la metamorfosis política, retomando la idea de pobreza como una esperanza que aguarda el apoyo de las fuerzas sociales, de las fuerzas revolucionarias.

En principio, existe una duda inherente en lo que provenga del extranjero, el revolucionario de América Latina ve con recelo las usanzas culturales o académicas extranjeras, porque lo extranjero hace referencia al origen de la maldad, mientras que es espacio de lo bueno, de lo divino, está relacionado con todo lo reverenciado

8 BERRYMAN, Phillip. Teología de la liberación. Los hechos esenciales en torno al movimiento revolucionario en América Latina y otros lugares, 1989, p. 11. 
como originario, nativo, histórico, hereditario, sagrado, en sí, todo lo concebido como parte de la idea de sabiduría ancestral. El mesías ve con recelo la institucionalidad de la iglesia, y su autoridad en la vida personal $\mathrm{y}$, sobre todo, en la vida comunitaria, porque lo comunitario es primario, el espacio comunitario es previo al espacio individual, y previo a cualquier institucionalidad. El revolucionario intenta alejarse de lo extranjero, mientras se junta al aura espiritual de lo comunitario. La espiritualidad de lo comunitario confluye con la imagen del mesías, una imagen de héroe mientras vive, y de mártir, cuando muere, especialmente si ha fallecido en batalla. Existe el peligro de una muerte dulce y acomodado porque la vida de mesías empieza a conjurarse entre nubes espesas de dudas, de interrogantes, de acusaciones de falso profeta. Todo revolucionario está dispuesto a morir, pero si lo rehúye, su imagen empieza a desmoronarse entre las nuevas generaciones. Por ejemplo, la defunción de Fidel Castro, el 25 de noviembre de 2016, despertó las dudas en la región porque, a pesar del discurso revolucionario, su vida se vio relacionada con la opulencia, con la buena vida. La vida de Castro contrajo una imagen de un revolucionario, pero al mismo tiempo, la imagen de un acaudalado burgués. Su vida acarreó sobradas contradicciones como para advertirlo dentro de una aurora divina. Por otro lado, la referencia opuesta se encarna en el ejemplo de Ernesto Guevara, la imagen del Che se ha elevado como mártir, su nombre es casi un ícono sagrado en la retórica revolucionaria.

La presencia del imperio entraría en el discurso no solo como un ente necesario para la subsistencia de la revolución, sino con una carga histórica muy pesada, una carga que se pesaba a través de las doctrinas regionales. Los intereses hegemónicos del imperio han creado esta carga histórica que permite la justificación de la sedición. Sin aviso, América Latina recorría la vereda trasera del imperio, $y$, sin aviso, se vio sumergida en doctrina internacionales de las cuales jamás gozó de voz ni voto, su participación fue escasa e inservible. El hegemón había erigido la primera doctrina que incluiría a su patio trasero de forma permanente, en un intento de declaración de pertenencia. El hegemón actuaría con la ayuda de la guía de la Doctrina Monroe. Los nuevos gobiernos de América 
Latina pasaron a ser parte del protectorado norteamericano. Así, la revolución se dotaría de argumentos y razones: se había pasado de la dominación española al protectorado estadounidense, sin dejar sitio para el titubeo, para la duda, o para la recriminación.

La idea de protectorado era regional, mientras Europa no se inmiscuía en asuntos americanos, los Estados Unidos no se inmiscuirían en temas europeo. La doctrina del protectorado no consentía influencias externas a los "continentes americanos, por su condición libre e independiente, la cual han asumido y mantenido, de aquí en adelante no pueden ser considerados como sujetos de futuras colonizaciones por parte de poderes europeos" ${ }^{9}$. La Doctrina Monroe, publicada en 1823, se consolidó como un compromiso entre potencias, mientras Europa se abstenía de intervenir en los asuntos del continente americano, los Estados Unidos no intervendrían en las colonias europeas. Este pacto no fue entendido como protección a las nuevas democracias de América Latina del absolutismo europeo, sino, más bien, como un protectorado con un nuevo imperio, con un nuevo líder, con un nuevo hegemón: la intervención del hegemón echó raíces sobre un terreno fértil, un terreno cuyos habitantes estarían atentos a los sucesos que se trasmitían sobre la Revolución Rusa, habitantes que habían leído sobre la rebelión y la lucha de clases, y habitantes que soñaban con la independencia del sistema occidental.

Para las ideas de revolución, el trasfondo, intenciones o intereses del protector de la región no eran importantes, para la revolución, lo único significativo era reconocer que la región pasó de una colonia a un protectorado. El nuevo hegemón del mundo occidental comenzaría su travesía fundamentada en el crecimiento económico acaecido en la Revolución Industrial. La influencia del imperio se expandiría a través de los vínculos comerciales y políticos, los cuales ofrecían democracia con prosperidad, libertad de la mano de la justicia, y equidad en conjunto con los derechos. Las promesas de la relación con el imperio servirían como un velo

9 ROOT, Elihu. The Real Monroe Doctrine. The American Journal of International Law, 1914, vol. 8, no 3, p. 427. DOI: 10.2307 / 2187489. Traducción hecha por el autor. 
delgado que cubriría otro interés, la generación de un protectorado que revivía las colonias europeas: era escaso el conocimiento que América Latina sobre la posible intervención castrense que intentaría devolver el régimen totalitario de Fernando VII, su triunfo llevó a especular en las condiciones que permitirían enviar una excursión militar para reintegrar al Imperio español sus antiguas colonias, "la mera posibilidad de que las naciones absolutistas intervinieses en el Nuevo continente alarmó de sobremanera a Estados Unidos, que temían un escenario regional rodeados de enemigos comerciales e ideológicos" ${ }^{\prime 10}$.

La protección del hegemón empezaría en el siglo XIX, y se expandiría rápidamente durante las primeras décadas del siglo XX. Empero, la esperanza del protectorado encontraría el primer punto de quiebre durante la Gran Depresión de 1929. La promesa de prosperidad se acabaría con la mayor crisis económica del siglo. La depresión golpearía a la región de manera singular: mientras se generaba una suerte de vibrantes discursos en contra del imperio, se intentaba construir una teoría propia de crecimiento. Los intentos fueron fructíferos, el intento de desarrollo a partir del consumo y crecimiento interno se conocería como Industrialización y Sustitución de Importaciones, ISI. De esta forma, la discursiva revolucionaria encontraría un nuevo sustento económico en el cual fundamentarse: el alejamiento del centro, como causante de un crecimiento dependiente del accionar del hegemón y sus aliados, mientras se procuraba generar estructuras de relaciones políticas y comerciales con los países de la periferia. De a poco, la ISI se vería como el brazo fuerte del discurso revolucionario: es posible crecer sin depender del hegemón, es posible prosperar sin las promesas del liberalismo, es posible vivir por fuera del protectorado.

El fracaso del modelo de la ISI apenas se vería en las décadas de los setenta y ochenta. Mientras tanto, el segundo

10 MUELA MORILLO, Javier. En: The Social Science Post. América para los americanos: la Doctrina Monroe y la Política de EE.UU en Latinoamérica. 17 de mayo 2018. Disponible en: http: / / thesocialsciencepost.com/es/2015/04/america-para-los-americanos-ladoctrina-monroe-y-la-politica-de-ee-uu-en-latinoamerica/ 
punto de quiebre surge después de la Segunda Guerra Mundial. El alejamiento del hegemón se profundiza durante la Guerra Fría, cuando el romanticismo discursivo se encarna en la Revolución rusa, la Revolución comunista china, y, por supuesto, de la Revolución cubana. El discurso de izquierda tomaría un giro pragmático: los fundamentos económicos y políticos se encarnaron en proyectos que, a primera mano, parecían conformarse como la respuesta a la influencia del imperio. El discurso económico no se basaría únicamente en Marx, y el post marxismo, sino en Keynes, por un lado, y Prebisch y Singer, por otro lado. Además, el discurso político se fundamentaría en los experimentos llevados a cabo de Cuba, en la Unión Soviética y en China.

El tercer punto de quiebre surgiría con el aparecimiento de las más crueles opresiones gubernamentales del continente, todas con un objetivo evidente, el exterminio de todo movimiento social o político que tenga relaciones con el comunismo o con sus agentes subversivos. Las dictaduras tendrían el apoyo subrepticio del hegemón, y tendrían el tiempo y el espacio para cumplir con su misión, aunque ello recurra en la muerte de miles de personas. En esta ocasión, el sentido del gran hermano, de protector, de imperio, se fortalecería en una visión mono focal: el comunismo debe ser detenido, aunque ello incurra en la aceptación de la violencia como política de los gobiernos latinoamericanos, los focos activos de promulgación del comunismo habían de ser disipados a cualquier costo, aunque esto represente la aprobación y apoyo a las dictaduras más sangrientas de la vida republicana de la región latinoamericana.

El imperio, que había protegido a América Latina del absolutismo europeo, escasas décadas más tarde, amparaba la imagen de estabilidad regional sobre la idea de democracia, "un buen gobierno generalmente ha significado estabilidad, no democracia"11 - Durante la Guerra Fría, la estabilidad se convirtió en el manto que ocultó las masacres, el hegemón impulsaba, en unos casos, y aceptaba, en otros, dictaduras como: la dictadura de la familia

11 SCHOULTZ, Lars. Beneath the United States: a history of US policy toward Latin America. Cambridge: Harvard University Press, 1998, p. 316. Traducción hecha por el autor. 
Somoza en Nicaragua, Fulgencio Batista en Cuba, Jorge Rafael Videla, y la cúpula militar durante el Proceso de Reorganización Nacional en Argentina, Rafael Leonidas Trujillo en República Dominicana, Augusto Pinochet en Chile, Omar Torrijos en Panamá, Alfredo Stroessner en Paraguay, etc. La aprobación y soporte del Hegemón a algunas dictaduras en América Latina contribuyeron en la confirmación y continuidad de las pasiones en contra del imperio. La coerción proveniente de una esfera de modernidad que abrió el espacio para la insubordinación. Una insubordinación violenta hasta finales del siglo XX, y luego, a principios del siglo XXI, una insubordinación que se plasmó en asambleas constituyentes. Lo novedoso de los nuevos movimientos socialistas fue el uso de instrumentos democráticos para llegar al poder, y una vez allí, cambiar las estructuras del poder político. Las asambleas constituyentes cambiarían el panorama político, proveyendo a la figura presidencial de una autoridad que sobrepasaría la división de poderes.

Los quebrantamientos de las promesas del liberalismo fundamentaron las raíces del discurso y la practicidad de la revolución durante la segunda mitad del siglo XX. Los resultados del quebrantamiento se visualizaron en la multiplicidad de grupos armados que se estructuraron bajo un principio esencial, la demolición de las estructuras occidentales, dentro de las cuales recaen los sistemas democráticos y el capitalismo. Sin embargo, a partir del siglo XXI, la opción era clara: ganar las elecciones, crear una asamblea constituyente que favorezca la representatividad del presidente, y cooptar las funciones del Estado, de forma que puedan moverse únicamente dentro de los permisos del líder revolucionario, de los permisos del presidente vitalicio. En este caso, la democracia se transformaría rápidamente en una copia coherente de la dictadura del proletariado, un espacio político en el cual la voz que se obedece es la voz del presidente, elegido del pueblo, es decir, el mesías elegido, del cual se hablaba durante el siglo XX. La organización de la escuela marxista no fue la primera opción para la región, el sentimiento de rebelión de América Latina no encontró fuente de desahogo, por ello, no tuvo otra elección más que entremezclarse 
con la pulsión de subsistir por fuera de la burbuja de influencia del imperio, "Perón interpreta que el giro cubano hacia Moscú ha sido forzado por las circunstancias, por una suerte de realismo necesario para sobrevivir" ${ }^{12}$.

Una vez que el discurso ha encontrado al enemigo encarnado en el imperio, o en el proletariado, o en la prensa, cualquier intento de retomar una versión conjunta de desarrollo se convierte en la plataforma para la acusación rotunda, agresiva y continua. Después de pensar en el imperio como el villano, toda tentativa de proximidad es, entonces, tachado como convenciones contemporáneas de opresión, colonialismo y hegemonía, verbigracia: todo intento de negociar un tratado de libre comercio; la intervención en frente al narcotráfico; la aparición de entidades internacionales o de instituciones financieras; las sociedades privadas extranjeras, etc. El presidente Hugo Chávez lo había mencionado de forma clara cuando hace su crítico al socorro estadounidense en Haití después del terremoto de 2010: "uno ve los infantes de marina con ametralladoras y fusiles y disparando, además, disparándole a los saqueadores. No sé a cuántos han matado a estas alturas, pero ellos entran allí con licencia para matar a quién sea y dónde y cómo sea. Terrible esto del imperio"13.

Josué de Castro pensaba que no hay otro medio más vigoroso que la violencia: "Yo, que he recibido un premio internacional de la paz, pienso que, infelizmente, no hay otra solución que la violencia para América Latina" ${ }^{14}$. Durante el siglo XX se pensó en revolución especialmente por medio del uso de las armas: El uso de las armas se contextualizaba en los movimientos guerrilleros, y los movimientos guerrilleros retomaban su discurso alrededor de las ideas marxistas. En el siglo XXI, el trasfondo discursivo de la revolución hacía uso

12 CRISORIO, Carolina. La Argentina en la Segunda Posguerra y la Revolución Cubana. La década de 1960. En: RODAS, Germán. Cuba y Latinoamérica en los años 60. Quito: Ediciones La Tierra, 2009, p. 26.

13 BANHEIRENSE. Hugo Chávez acusa EUA de entrarem no Haiti com "Licença para matar". Disponible en: https:/ / youtu.be/g1xWote0iJM

14 GALEANO, Eduardo. Las venas abiertas de América Latina. Siglo XXI, 2004, p. 5. 
de los medios democráticos, la revolución se adecuó mediante el uso de las nociones liberales con igual propósito, la fundación de una nación que persiga las utopías comunistas. Además, durante las dos primeras décadas del siglo XXI, la noción de comunismo también se acomodó, la imagen había sido deteriorada por los experimentos en la Unión Soviética en China, los movimientos revolucionarios no se llamaban así mismo como comunistas, sino como progresistas, la esencia de las elecciones abría espacio para considerar que el autoritarismo de izquierda podía convivir con la democracia. Sin embargo, los resultados fueron parecidos, y el fin seguía siendo el mismo: la utilización de elementos liberales que justifiquen la consumación de un Estado socialista ${ }^{15}$.

El gobierno de corte liberal propone el amparo a la libertad, la vida, y la búsqueda de la felicidad ${ }^{16}$ como principios indefectibles del Estado de derecho. Sin embargo, las corrientes revolucionarias del siglo XXI, hicieron uso de estos principios como una forma de justificación basada en la utopía del bienestar posible dentro de una sociedad socialista. El liberalismo sirvió como tribuna para la formación de un nuevo marco constitucional, el cual evidencie la necesidad de un nuevo contrato social, la necesidad de una constitución socialista. Los principios liberales solo fueron utilizados de plataforma discursiva: en el discurso, sobresalían las ideas liberales sobre elecciones libres, división de poderes, y libertad, empero, estas ideas se mezclaban con la eliminación de la propiedad privada, con el cambio de los medios de producción y, especialmente, con la instauración de gobiernos que estén centrados en un mandamás, el revolucionario, el elegido, el mesías.

Dentro de la lógica del socialismo del siglo XXI, la libertad se concibe dentro de un nuevo contrato social, una nueva estructura legal la cual recae en una paradoja: la libertad se entiende en tanto y cuanto se la cede al gobernante revolucionario, aquel camarada

15 Aquí, el comunismo y el socialismo se han utilizado sin mayor diferencia porque las escuelas de pensamiento político proponen una línea muy delgada entre uno y el otro término. Sin embargo, las connotaciones nos llaman a suponer al socialismo como un modelo que acepta ciertos principios liberales mientras que el comunismo supone una autoridad total del estado.

16 Principios a través de los cuales de redactó la Declaración de Independencia de los Estados Unidos. 
de lucha quien conoce cómo administrar la nación, para llevarla a una fase de colectividad social: el ciudadano es libre en tanto y cuanto la entregue al líder revolucionario, en tanto y cuanto se someta, y en tanto y cuanto no conspire con ideas liberales. Así, el contexto reabre el camino para cambiar las definiciones de conceptos comunes: se propone consentir la entrega de la libertad propia a un bien comunitario, colectivo: se propone la entrega del individualismo para que sobresalga el colectivismo. De la misma forma, cualquier acto de desobediencia al nuevo contrato social encarnaría la represión feroz del gobernante: no existe espacio para el desacuerdo, todos los asentimientos deben estar anexados a este nuevo contrato social, cualquier otro tipo de consenso será preciado como actos de insubordinación.

La revolución propone la idea de libertad como el elemento central para la subsistencia del proyecto socialista: la libertad socialista compromete la sumisión, sin sumisión, el proyecto enfrentaría inestabilidades políticas que afectarían su continuidad. Así, se espera un sentido de lealtad inquebrantable al gobernante, aquel que fue escogido por el proletariado como mesías. El gobernante entiende la libertad íntimamente relacionado con la construcción de un nuevo contrato social, íntimamente relacionado con la creación de una nueva estructura constitucional. Además, el gobernante lleva la consigna clara: la denuncia con vehemencia de todo alto de insurrección, la persecución en la continuidad de la insubordinación, y la represión ejemplificadora, digna de todo revolucionario. El líder revolucionario lo tiene claro: los términos en los que se erige el Estado son rígidos, inamovibles, pensados desde la revolución, razonados a partir de un nuevo contrato social: se denuncia que hemos existido en un pacto social en el cual no gozamos de voz, ni voto y, por ello, la conciencia colectiva del proletariado ha dotado a las revoluciones sudamericanas, especialmente del siglo XXI, de un distinto sentido de responsabilidad, la responsabilidad de instituir una nueva constitución, la cual funde un sistema socialista, justificándolo a través de referéndums aprobatorios. 
Esta nueva construcción del sistema de legalidad nacional recoge, entonces, los principios del socialismo, destacando un sentido intenso de soberanía, independencia y nacionalismo, partiendo de la afirmación de que la revolución se enmarca en "las luchas sociales de liberación frente a todas las formas de dominación y colonialismo... Un país democrático, comprometido con la integración latinoamericana- sueño de Bolívar y Alfaro"17. De esta manera, se ha repensado en la revolución una y otra vez, sin embargo, en todas las ocasiones, dos elementos surgen como partes sine qua non, el romanticismo y el mesianismo. Por un lado, el romanticismo dibuja la posibilidad de una suerte de moralidad, donde los delincuentes, aquellos contrarrevolucionarios o amantes del imperio, sean consumados, y donde se invoque un sistema discursivo de eliminación de la pobreza y la miseria. Por otro lado, el mesianismo dibuja el semblante del libertador, sea con un rifle colgando del hombro o a través de un manto democrático, cuyo sostén electivo justifique la permutación del sistema. El mesías, revolucionario del siglo XXI se eleva mediante de procesos electorales para instaurar un nuevo gobierno, un Estado que descifre la presencia del socialismo del siglo XXI a partir de la separación del imperialismo, y a partir de políticas que glorifiquen las pasiones alrededor de la soberanía y el nacionalismo.

El romanticismo de la revolución observa la verdad desde la locución emancipada de las emociones, y reconstruye, además, la idea del mesías con aquel líder que llevará de la mano al pueblo hacía el fin de la historia, o, por lo menos, a la dictadura del proletariado. Es el mesías, parte del proletariado, quien ha sufrido, vivido y brotado por dentro del pueblo ellos, el ungido, llamado a levantarse como rey de los oprimidos: su misión, establecer el reino del pueblo, mientras desaparece el capitalismo, mientras muestra la única vía a la salvación: “Nada ni nadie podrá detener la gran revolución suramericana, latinoamericana y el caribe, el mundo debería apoyar la revolución, porque esa revolución es el inicio al camino de la salvación de este planeta amenazada por 
el capitalismo, por las guerras, por el hambre"18, declaraba Hugo Chávez en la Asamblea de las Naciones Unidas en septiembre de 2009. Y, adiciona, durante su discurso en la Cumbre Climática de las Naciones Unidas, en Copenhague, el 16 de diciembre del 2009: "más fácil será que un camello entre por el ojo de una aguja, a que un rico entre al reino de los cielos [...] ¿Puede una Tierra finita soportar un proyecto infinito? La tesis del capitalismo: el desarrollismo infinito, es un modelo destructivo“ ${ }^{\prime 1}$.

El espíritu del mesías ha caminado la historia latinoamericana desde los primeros pasos republicanos, y se ha encarnado múltiples veces, en espacios y temporalidades diferentes, en procesos políticos disparejos, con una gama pequeña de actores: mártires, dictadores vitalicios, y otros falsos profetas. Todos con idéntica misión: socorrer a Latinoamérica de la estructura hegemónica, del imperio del mal y de sus delegados terrenales. La intención es la misma: destruir la organización del mal encarnada en el capitalismo y en sus aliados. Un fantasma recorría América Latina: el fantasma del mesías en el socialismo del siglo XXI, quien despierta de tiempo en tiempo para cubrir la sombra capitalista e instituir el reino socialista bajo el mandato del revolucionario, quién ha prometido expiar a todo aquel que se resista al proceso revolucionario, o dejarlos morir como última alternativa, verbigracia: Orlando Zapata, preso político, su muerte ocurrió en la Habana, en febrero de 2010, después de 85 días de huelga de hambre, Zapata imploraba que le dejen tener ropa limpia duchas diarias y comida caliente; unos pocos años previos, con propósitos muy similares, Pedro Luis Boitel falleció en mayo de 1972, en la prisión Castillo del Príncipe, después una huelga de hambre de 53 días.

18 CHÁVEZ, Hugo. Nada podrá detener la revolución en América Latina. The Omar Herald [en línea]. 26 de septiembre de 2009. Disponible en: http://omar-herald. blogspot.com/2009_09_01_archive.html

19 CHÁVEZ, Hugo. ¡No cambiemos el clima, ¡cambiemos el sistema! Rebelión [en línea]. 16 de diciembre de 2009. Disponible en: http:/ / www.rebelion.org/ noticia.php?id=97198 


\section{Capítulo 2.}

Arte y Revolución 
A partir del siglo XX, América Latina escribe una parte de su historia a partir de movimientos revolucionarios, algunos armados, otros con tinte democrático, haciendo uso las artes plásticas y escritas: una revolución escrita a través de fotografías, poemas, cuentos, canciones e historietas que revientan la tolerancia y la pasividad, y claman por un espíritu irreverente, reaccionario y revolucionario. Olas artísticas apoyaban los movimientos revolucionarios y se identificaban con su actitud insolente con el imperio, que se rebela en contra de su protectorado, y se identifica con su solución escogida, una revolución armada. Esta historia se revela como las primicias de una Latinoamérica libre de colonialismos y protectorados, y comparte una conciencia común a todos: un resentimiento durmiente que despierta de sopetón para desahogarse en el romance de la revolución. Este romance, reflejado en formas de la estética, es inherente a los cambios de época:

sería ridículo, absurdo e incluso estúpido hasta más no poder, pretender que el arte permanecerá indiferente a las convulsiones de nuestra época. Son los hombres los que preparan los acontecimientos, son los hombres los que los realizan, y los acontecimientos a su vez actúan sobre los hombres y los cambian ${ }^{20}$.

La idea de revolución reinterpreta la armonía de las sociedades, conjurando la noción de saberse actores y directores del drama en que vive Latinoamérica: el revolucionario recuenta su historia, acogiendo la autodeterminación de los pueblos por la razón o por la fuerza: “¡Allende presidente: por la razón o la fuerza!" ${ }^{21}$. Así, el drama latinoamericano pretende rescribirse desde una sola perspectiva, el punto de vista de los movimientos sociales, del proletariado y, sobre todo, del líder revolucionario, aquel que se tomará el poder y implantará la dictadura del proletariado. Este drama se conjura con ideas románticas sobre el fin de la historia,

20 TROTSKY, León. Literatura y revolución. Ediciones digitales Izquierda Revolucionaria, 2006, p.7.

21 LARRAÍN PARADA, Javier. La izquierda revolucionaria en Chile. En: RODAS, Germán. Cuba y Latinoamérica en los años 60. Quito: Ediciones La Tierra, 2009, p. 77. 
donde el comunismo sea el último estadio, ¡sea por la razón o por la fuerza!

Se ha quitado el velo de ignorancia en el arte, se requiere que el artista se suponga en un puesto de privilegio, en un estante que ha sido otorgado para que resalte al revolucionario sin ponerse a buscar los cuerpos muertos en el armario, sin detenerse a pensar sobre la posibilidad de la falibilidad. Rawls ${ }^{22}$ propone que una lectura justa de la sociedad requeriría encontrar o establecer un velo de ignorancia el cual nos prevenga de tomar partido de acuerdo a nuestra posición social, política o religiosa. En el caso del arte que defiende a la revolución, el velo de la ignorancia viene dado sin reparo: el revolucionario sabe lo que es bueno para la sociedad, no necesita de ningún velo para comprender lo que le conviene. El artista tiene solo que embalsamar al revolucionario y alentar sus propósitos.

La belleza de la revolución, contrastada por la costumbre de ver a América Latina como parte de un protectorado hegemónico, se ha encontrado con la pluma, el cincel, y la brocha, se ha encontrado con un artista con un don que ha revestido las ideas románticas de rebelión con lino y ropa fina, aunque se haga de la vista gorda de las de gotas de sangre en su borde, y aunque se haga de la vista gorda de los robos, secuestros, extorciones y fusilamientos. El artista resalta las hazañas heroicas, las batallas imposibles, la justicia social que promueve el revolucionario.

Se escriben relatos que conjugan su realidad, la realidad revolucionaria, como un juego entre la razón y la pasión, entre lo lógico y lo absurdo: una razón absurda, el imperialismo; una pasión lógica, la revolución. Latinoamérica se reencuentra y revive en las pasiones conspiradoras por el azar, sabiendo que la razón puede hacer más daño que la pasión, y, muchas veces, el azar puede obrar mejor que la lógica: "ese azar que hace tan bien las cosas, el azar hace muy bien las cosas en la historia, lo hace mucho mejor que la

22 RAWLS, John. Teoría de la justicia. Fondo de Cultura Económica, 2012. 
lógica, en un momento histórico importante para América Latina, en que está dominada por un imperialismo que la quiere convertir en una factoría, en una colonia" ${ }^{23}$.

Uno de los más importantes escritores argentinos del Boom Latinoamericano, Julio Cortázar, recibe, en 1983, la Orden de la Independencia Cultural "Rubén Darío" del pueblo sandinista, a quien admiraba por su constante lucha en contra de la dictadura de los Somoza: "esta revolución que me une con un lazo de amor"24. Cortázar había generado vínculos afectivos con los procesos revolucionarios, sean o no armados, no sabemos si por un apego inherente a los movimientos de izquierda, o por una reacción impulsiva en contra del intervencionismo estadounidense. En 1978, acerca de su natal Argentina, Cortázar escribía que

El embajador de Estados Unidos ha entregado a la Junta Militar argentina una lista de los prisioneros político recopilada por sus servicios de información, y que alcanza a un total de 10.000 personas... [irónico es]que después de haber favorecido abiertamente tantas dictaduras militares en Argentina, se indigne ahora del número de presos politicos en el país ${ }^{25}$.

La Revolución cubana propuso un espacio de intercambio de los intelectuales de izquierda de la región latinoamericana, pero también se convirtió en un espacio imaginario de ilusiones, donde las artes y el pensamiento crítico se encontraban en un mismo espacio. Sin embargo, aunque Cortázar parecía aprobar la Revolución cubana y sus ramificaciones, veía la idea de revolución con un matiz diferente, proponía que "literatura no debía describir

23 SOLER SERRANO, Joaquim. Julio Cortázar en A Fondo (1977). Disponible en: http: / www. rtve.es/alacarta/videos / a-fondo/ entrevista-julio-cortazar-programa-fondo/1051583 /

24 CORTÁZAR, Julio. Julio Cortázar ante la Orden de la Independencia Cultural "Rubén Darío". Ventana, 12 de febrero de 1983.

25 CORTÁZAR, Julio. El escritor y el lector bajo las dictaduras en América Latina. El País, 25 de junio de 1978. 
ni apoyar ideológicamente el proceso revolucionario, ni siquiera posicionarse políticamente ante un tema u otro, sino revolucionar el universo de la representación literaria y producir una posición de lectura que exigiera al lector un trabajo digno del 'hombre nuevo' guevariano" ${ }^{26}$. Aunque Cortázar tenía una amistad entrañable con los procesos revolucionarios, su pensamiento libre fue espacio de crítica por parte de otros escritores que creían que era el momento de resaltar la revolución en toda su dimensión. Jaume Blames ${ }^{27}$ relata el acoso del escritor colombiano, Oscar Collazos, a Cortázar por escoger una actitud de visión independiente, a espaldas del proceso revolucionario latinoamericano, recurriendo constantemente a la experimentación vanguardista, cuando debía colaborar en la construcción del socialismo.

Cortázar no tomó el camino de separación completa de las prácticas de la Revolución cubana, como sí lo hicieron Mario Vargas Llosa, Juan Goytisolo, Carlos Fuentes, Hans Magnus Enzensberger y Jean-Paul Sartre. Cortázar se mantuvo en un ambiguo apoyo, en respaldo "a la gran lucha de liberación que está en marcha, y que fue la aspiración de Simón Bolívar y José Martí, y es hoy la tarea de los hombres como Fidel Castro y Ernesto "Che" Guevara"28. Aunque las relaciones con la Revolución cubana eran ambiguas, siempre mantuvo una estrecha relación de amistad y apoyo a la Revolución Sandinista en Nicaragua.

26 BLANES, Jaume Peris. “ Libro de Manuel” de Julio Cortázar, entre la revolución política y la vanguardia estética. Cuadernos de investigación filológica, 2005, no 31, p. 146.

27 Ídem.

28 MANJARREZ, Héctor. La revolución y el escritor según Cortázar. Cuadernos Políticos, 1984, no 41, p. 91. 


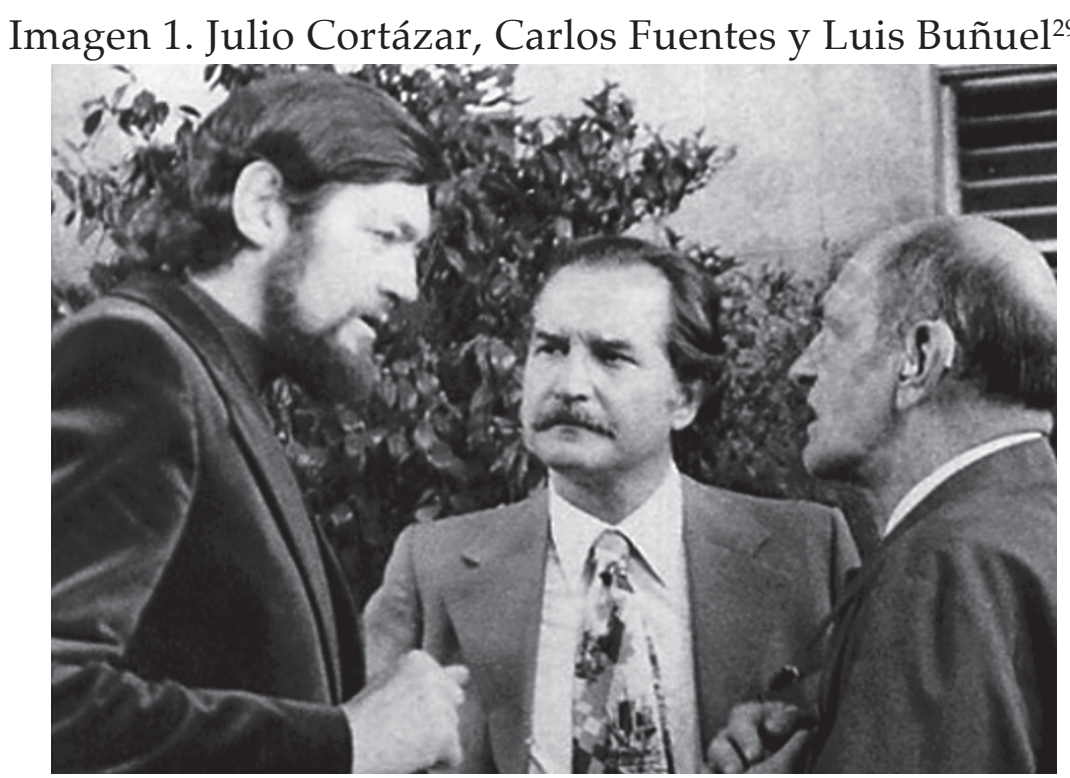

Gabriel José de la Concordia García Márquez, premio nobel de literatura en 1982, otro de los personajes relevantes del Boom Latinoamericano, tenía una estrecha relación con Fidel Castro. Márquez no estaba interesado en la activa relación entre la política y el arte, "la pulsión por la política, en su caso, fue más tardía. Y mucho contribuyó la caída de Salvador Allende y la instauración de una dictadura militar en Chile" 30 . Su novela El Otoño del Patriarca, publicada en 1975, empieza a revelar la relación inquieta y dinámica que se construiría entre el arte, la denuncia de las dictaduras opresoras de las décadas pasadas (excluyendo, obviamente, a Cuba), y su pasión casi reverente por la Revolución Cubana.

Su apoyo a la revolución lo llevo a distanciarse de muchos escritores, pensadores y artistas de América Latina. El primer caso de notorio aprecio a Castro ocurrió en 1971, cuando el poeta cubano, Heberto Padilla, fue acusado de actividades subversivas en contra del gobierno por su poemario Fuera del juego, donde se encontraba una crítica velada a la revolución. Para poder acceder a su libertad,

29 ETIENNE, Jules. Carlos Fuentes sobre el vanguardismo de Julio Cortázar. Disponible en: $\quad$ http: / / mitosyreincidencias.blogspot.com/2013/05/carlos-fuentes-sobre-elvanguardismo-de.html

30 JOFRÉ, Alejandro. Fidel Castro y Gabriel García Márquez: historia de una amistad. La Tercera [en línea]. 27 de noviembre de 2016. Disponible en: http:/ / www.latercera.com/ noticia/ fidel-castro-gabriel-garcia-marquez-historia-una-amistad/ 
fue obligado a redactar una declaración de inculpación. Después de un mes de encarcelación, Mario Vargas Llosa organizó una respuesta en contra del régimen castrista firmada por 61 intelectuales. La respuesta decía:

Creemos un deber comunicarle nuestra vergüenza y nuestra cólera. El lastimoso texto de la confesión que ha firmado Heberto Padilla solo puede haberse obtenido mediante métodos que son la negación de la legalidad y la justicia revolucionarias. El contenido y la firma de dicha confesión, con sus acusaciones absurdas y afirmaciones delirantes, así como el acto celebrado en la UNEAC en el cual el propio Padilla y los compañeros Belkis Cuza, Malé, Díaz Martínez, Cesar López y Pablo Armando Fernández se sometieron a una penosa mascarada de autocrítica, recuerda los momentos más sórdidos de la época del salinismo, sus juicios prefabricados y sus cacerias de brujas. [...] El desprecio a la dignidad humana que supone forzar a un hombre a acusarse ridiculamente de las peores traiciones y vilezas no nos alarma por tratarse de un escritor, sino porque cualquier compañero cubano -campesino, obrero, técnico o intelectual- pueda ser también víctima de una violencia y una humillación parecidas [... $]^{31}$

Los firmantes más destacados de la carta fueron: Jean-Paul Sartre, Simone de Beauvoir, Susan Sontag, Carlos Fuentes, Octavio Paz, y Mario Vargas Llosa. Uno de los pocos intelectuales que se rehusó a firmar la carta fue Gabriel García Márquez. A pesar de la dura crítica en contra del afamado escritor colombiano, "García Márquez declaró que su adhesión al régimen de Fidel era como el catolicismo, una comunión con los santos" ${ }^{\prime 32}$. Aunque parecer que la amistad con Fidel Castro no pasó de forma espontánea, sino que fue buscada y anhelada por Márquez, la primera vez que se encontraron en la Habana, "García Márquez pasó un mes completo

31 ALFONSO, Rodolfo. Autocrítica de Heberto Padilla. Cuba/Cultura/Revolución, 1971, no 20 , p. 8.

32 JOFRÉ, Alejandro. Fidel Castro... Op. Cit. 
en el Hotel Nacional de La Habana esperando la ansiada llamada del comandante" 33 . La añorada amistad se hizo visible para todo el mundo y, a pesar de todas las denuncias en contra de la dictadura Castrista, el memorable escritor colombiano seguiría apoyando la Revolución Cubana sin espacio a la duda.

Imagen 2. Gabriel García Márquez y Fidel Castro ${ }^{34}$.

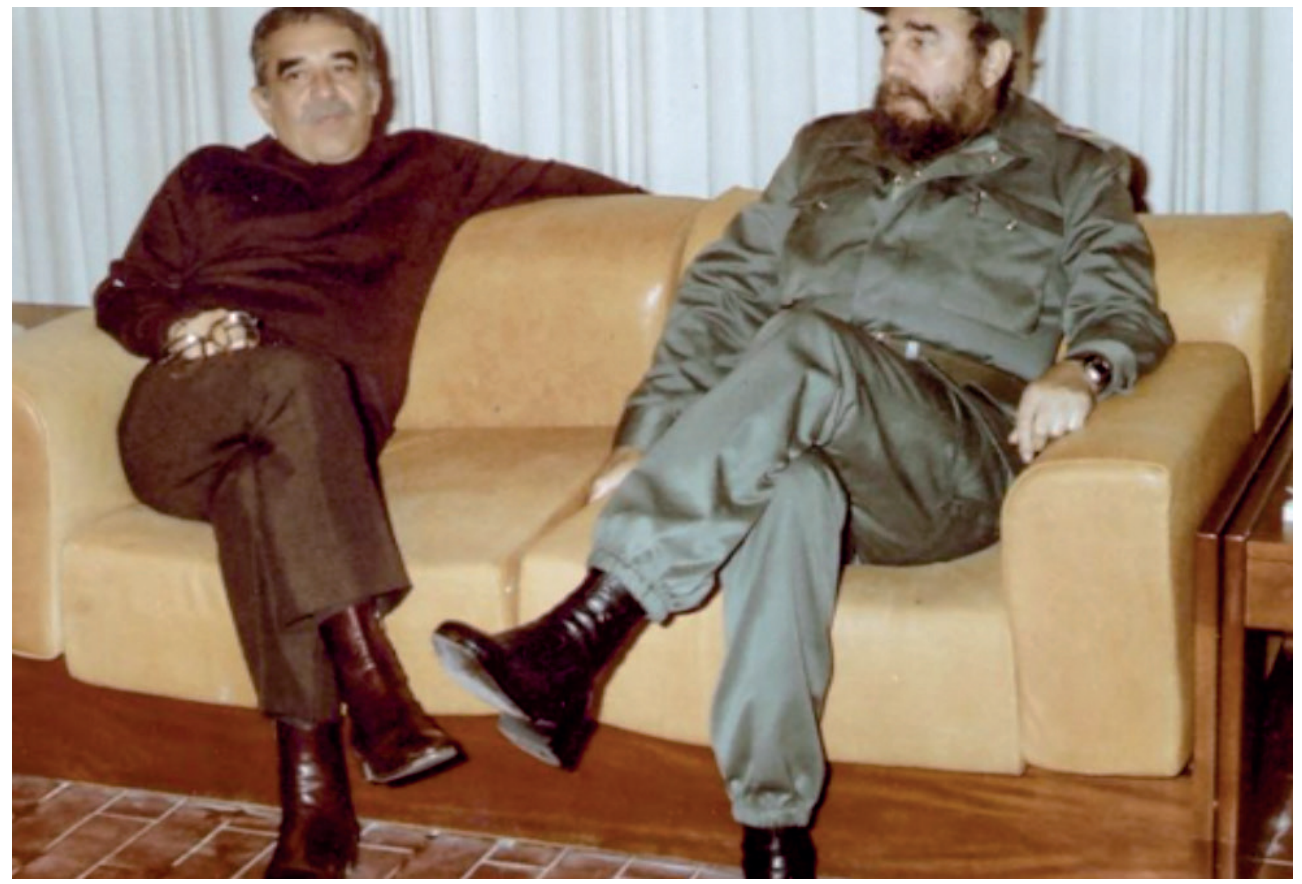

El gran Mario Benedetti, escritor uruguayo, tenía una relación muy activa con las ideas revolucionarias. De hecho, en los setenta, se afilió al Movimiento de Liberación Nacional Tupamaros, sin embargo, tuvo que salir al exilio a causa del golpe de estado de 1973. Pasó por Argentina, Perú, Cuba, y España. Su amor a la revolución fue constante, de hecho, lo llevo a enfrentarse a Mario Vargas Llosa en varias ocasiones. En un debate en 1984, organizado por el diario El País de España, "Vargas Llosa menciona al intelectual latinoamericano como un factor importante del subdesarrollo político en Latinoamérica. Le consta que un creador puede ser innovador en la literatura y dogmático ideológicamente. Subraya

\begin{tabular}{ll}
\hline 3 & Ídem. \\
34 & Ídem.
\end{tabular}


que su crítica no es que los intelectuales sirvan a cierto partido, sino que no piensen por sí mismos ${ }^{35}$.

Su apoyo intelectual a los procesos revolucionario no cesó. Su talento llevo a Mario Benedetti a publicar en Internet su poema titulado "CHE 1997", a razón del aniversario 80 del nacimiento de Ernesto Guevara de la Serna:

Lo han cubierto de afiches / de pancartas de voces en los muros de agravios retroactivos de honores a destiempo lo han transformado en pieza de consumo en memoria trivial en ayer sin retorno en rabia embalsamada han decidido usarlo como epílogo como última thule de la inocencia vana como añejo arquetipo de santo o satanás y quizás han resuelto que la única forma de desprenderse de él o dejarlo al garete es vaciarlo de lumbre convertirlo en un héroe de mármol o de yeso y por lo tanto inmóvil o mejor como mito o silueta o fantasma del pasado pisado

sin embargo, los ojos incerrables del Che miran como si no pudieran no mirar asombrados tal vez de que el mundo no entienda que treinta años después sigue bregando dulce y tenaz por la dicha del hombre ${ }^{36}$

Antes de su fallecimiento, Benedetti fue condecorado por el presidente Hugo Chávez, en 2007, en la Universidad de la República. Hugo Chávez dejo en el acto de condecoración que Benedetti es "uno de esos seres humanos, aquellos que dijo el poeta,

35 ENKVIST, Inger. Cuba y Fidel Castro fueron decisivos en el desarrollo del pensamiento de Vargas Llosa. Revista Hispano Cubana HC, 2003, no 17, p. 107.

36 BENEDETTI, Mario. Che 1997. Disponible en: http://www.poemas-del-alma.com/ mario-benedetti-che-1997.htm 
hay hombres que luchan un día, esos son buenos, hay otros que luchan un año, esos son mejores, pero hay otros que luchan toda la vida, esos son indispensables" ${ }^{37}$. Benedetti se convirtió en uno de aquellos artistas que apoyaron el socialismo del siglo XXI sin reproche y sin cuestionamiento porque ser parte de la revolución requiere de una fidelidad cuasi religiosa, irreprochable y, sobre todo, activa, un artista que alabe las ideas de revolución y las defienda en los espacios donde se desenvuelve.

\section{Imagen 3. Mario Benedetti y Hugo Chávez ${ }^{38}$.}

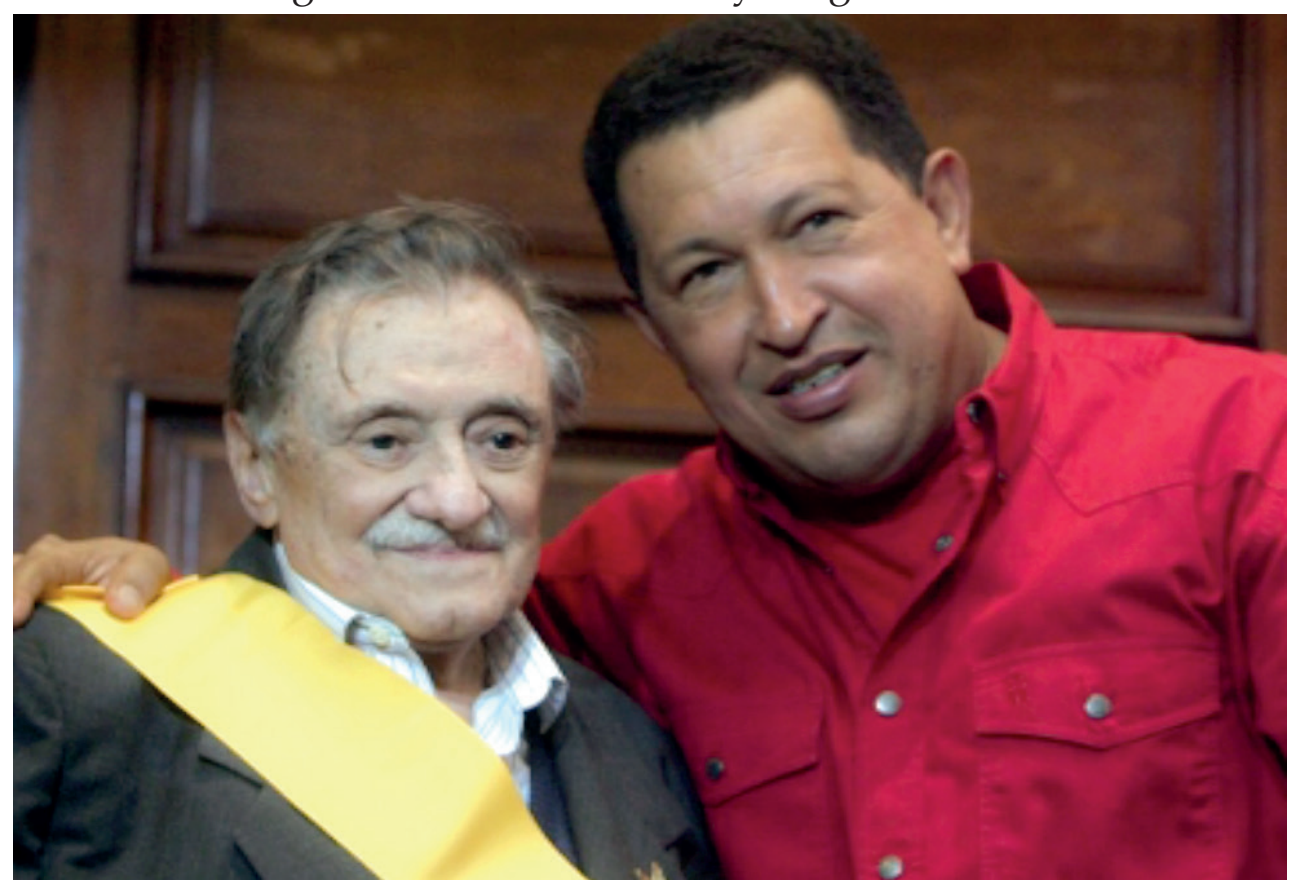

El arte no puede permanecer estático: las artes revolucionan en los cambios de época, mientras se reconocen como propias, y reconsideran el hecho de que Latinoamérica también produce referentes estéticos. Estos referentes emanaron simbolismos propios que fueron murmurados, luego comentados, luego comunes, y, por último, repetidos toscamente en las calles, bares, universidades,

37 CUIJIN, Mario Benedetti y Hugo Chávez en Montevideo. Disponible en: https: / www. youtube.com/ watch?v=S10zGIrley4

3810 encuentros de famosos con Chávez (+Fotos). Colarebo [en línea]. 3 de agosto de 2014. Disponible en: http://www.desdelaplaza.com/wp-content/uploads/2014/07/ Chávez-MarioBenedetti.jpg . 
camisetas, banderas: el Che de Alberto Korda, 5 de marzo de 1960: "Alberto Korda tomó la clásica foto del Che [...] Se hallaba a unos siete metros - ¿o eran diez?- de distancia del comandante guerrillero y, precisa, sí, que era una tarde opaca, invernal [...] la cabeza solitaria del Che se difumina en una luz pareja y suave" ${ }^{39}$.

Imagen 4. El Che de Alberto Korda ${ }^{40}$.

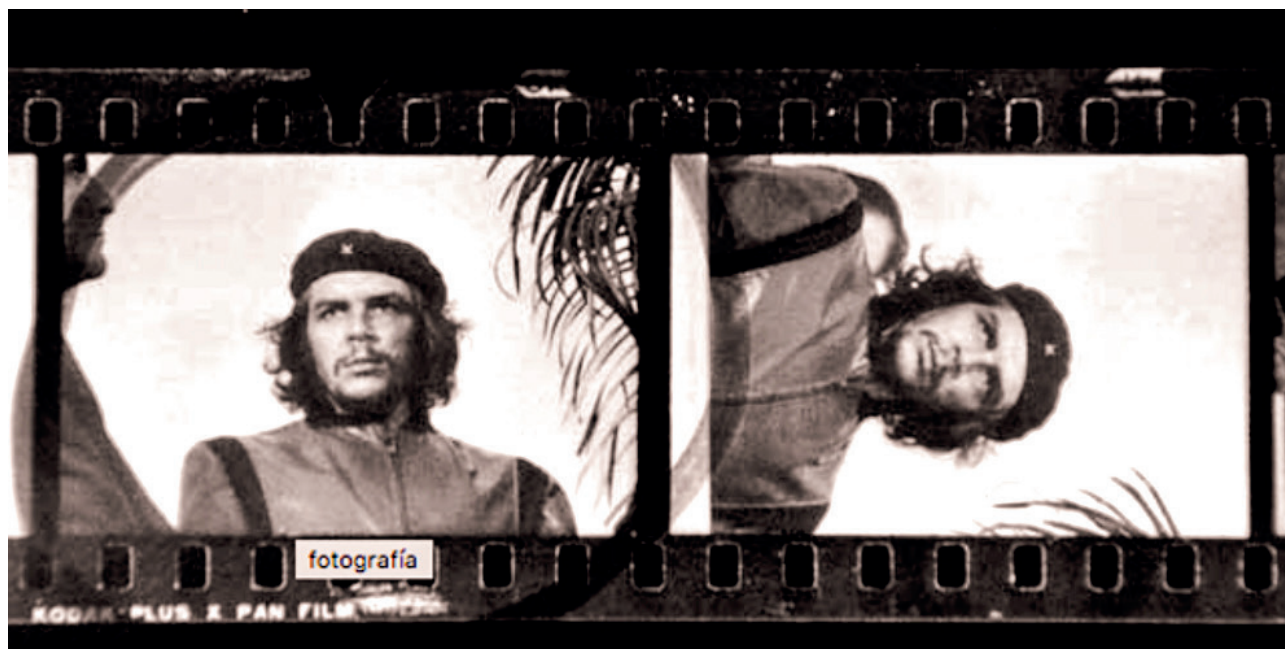

Las letras de los escritores latinoamericanos se revierten entre sus compatriotas con tal prontitud y exquisitez que su influencia en el espacio académico ha formado mundos paralelos: una burbuja, de sueños altruistas e ilusiones socialistas, contrastada con un mundo saturado, de acuerdo a Friedrich Nietzsche, de "hombres con una naturaleza inherente, bárbaros en todos los malos sentidos de la palabra, hombres cazadores, en posesión de una deseo inquebrantable de poder, se lanzan hacia los débiles, más morales, razas más pacíficas" ${ }^{41}$.

39 TORRES, José Antonio. La historia de una foto convertida en ícono. El Nacional [en línea]. 10 de octubre de 2009. Disponible en: http:/ / elnacional.com.do/la-historia-deuna-foto-convertida-en-icono/

40 KORDA, Alberto. El Fotógrafo del Che. Taringa [en línea]. Disponible en: http:/ / www. taringa.net/posts / offtopic/14527976/El-fotografo-del-Che.html

41 STUMPF, Samuel y FIESER, James. Philosophy... Op. Cit., p. 384. Traducción hecha por el autor. 
La revolución de la literatura o la literatura de la revolución recorre América Latina en una suerte de reencuentro con una identidad común. A saber, de todos quienes vivimos en este pedazo del mundo, la conciencia colectiva recorre por las calles, ciudades, universidades, bares, etc. como si hubiese vivido siempre entre nosotros, como si tal espíritu hubiere nacido en la parte sur del continente americano, como si tal literatura estaba siendo esperada por todos, no unos cuantos, sino unos muchos.

Las memorias no son frágiles pero las emociones perduran, aunque no recordásemos exactamente dónde empezó todo, aunque no supiésemos de dónde vino este espíritu antiimperialista, aunque, sabiendo cierta historia, no se entienda como esta descarga de emociones vinieron recargadas de despecho. Las emociones se convierten, entonces, en la conciencia colectiva: no hay lógica necesaria entre los argumentos y las emociones, pero, quizá, el hecho de sabernos propios, pueblos similares, con una historia común, recoge las emociones para revestirlas de cierto juicio, para galardonarlas entre sonetos: el romance avanza en tanto y cuanto la insurrección se multiplique.

Los pueblos apetecen de letras con referentes propios, quienes publiquen y hablen sobre los pueblos hispanos, con sus problemas diarios e ilusiones surrealistas. La historia, entonces, presenta a los pueblos hambrientos de personajes nuevos, de escritores nuevos, quienes se encontraron con un fenómeno nuevo: eran leídos por sus compatriotas. La relación entre un sentimiento creciente de revolución y el retorno a un público propio ilumina los procesos revolucionarios y los dota de un contorno emocional que se reverbera en escritores y líderes locales que intentan entender los procesos revolucionarios. A partir del triunfo de la Revolución cubana en 1959, “un sinnúmero de dirigentes del Tercer Mundo arribaría a la Habana a conocer la experiencia de la revolución y a tratar de entrevistarse con los líderes como Ernesto Guevara, Fidel Castro y otros. De Colombia sobresalen, además del joven escritor Gabriel García Márquez, los hermanos la Rotta, Fabio Vásquez, Franco 
(guerrillero de los Llanos Orientales) y Gilberto Vieira, secretario del Partido Comunista colombiano" ${ }^{42}$.

El arte hizo que los revolucionarios sean vistos como ungidos del destino, una suerte de entidad humana que se engendraba entre mártir, héroe y divinidad. Estos son aquellos que se vieron morir en batalla. A estos ungidos los conocemos todos, los erigidos como mártires no son difíciles de encontrar: Ernesto el Che Guevara, Salvador Allende, Augusto Sandino. Por otro lado, tenemos aquellos líderes vitalicios, aquellos que no se pudieron convertir en mártires, sino que se encarnaron en dictadores vitalicios: Fidel y Raúl Castro. $Y$, por último, tenemos aquellos que fueron considerados profetas populistas, autoritarios por encargo del destino, quienes hicieron uso de las herramientas democráticas para luego desmantelar la democracia ${ }^{43}$. Estos profetas tuvieron el suficiente tiempo para crear una realizada alternativa a través de un aparataje de comunicación estatal impresionante. Esta realidad alternativa, cual obra de arte, construyó una realidad en la que ocurría un milagro, el socialismo había colmado de felicidad a la región, la pobreza había disminuido. Estos caudillos aparecieron en el siglo XXI: Hugo Chávez, Daniel Ortega, Rafael Correa, Evo Morales, Néstor Kirshner y su esposa Cristina Fernández. Todos los anteriores son unidos por un mismo credo, una misma religión, todos emergen con un discurso similar, declarado por Augusto Sandino en 1927: "yo no estoy dispuesto a entregar mis armas en caso de que todos lo hagan. Yo me haré morir con los pocos que me acompañan porque es preferible hacernos morir como rebeldes y no vivir como esclavos" ${ }^{44}$.

42 CARO, Jorge Enrique y GONZÁLES, Roberto. Repercusiones de la Revolución Cubana en Colombia. En: RODAS, Germán. Cuba y Latinoamérica en los años 60. Quito: Ediciones La Tierra, 2009, p. 105.

43 Aquí la democracia no se la entiende únicamente como un proceso electoral, sino como un conjunto de principios. Estos principios son la división de poderes, el estado de derecho, y la protección de las libertades humanas.

44 BOLAÑOS, Alejandro. Sandino. Masaya, Nicaragua. Fundación Enrique Bolaños, 2002, p. 29. ISBN: 1-877926-54-X. 
Imagen 5. Augusto Sandino ${ }^{45}$.

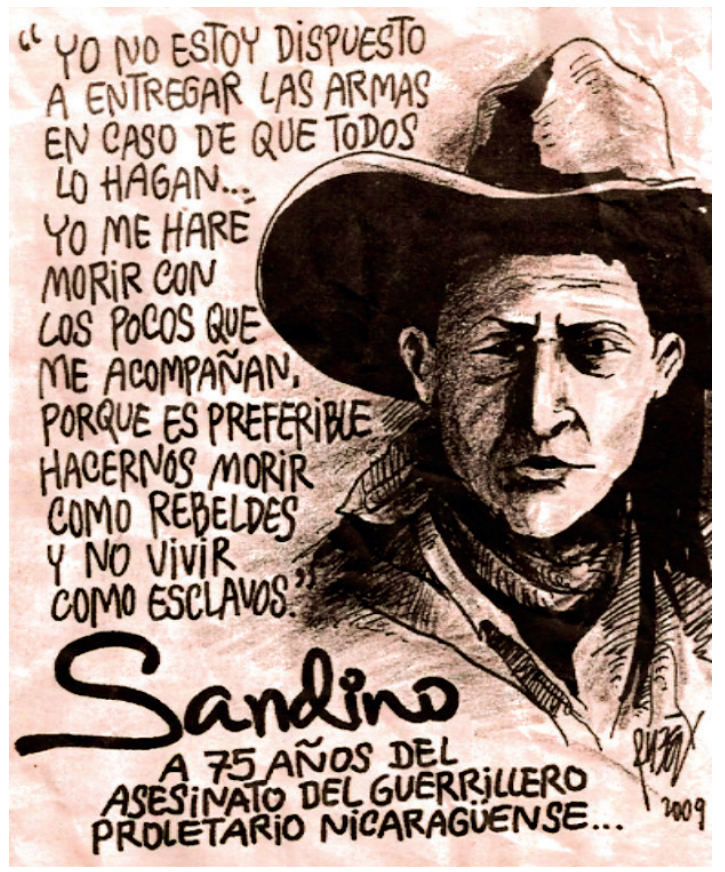

El espíritu del mesías nace y renace en Latinoamérica en una suerte de retorno eterno, donde la movilidad de los paradigmas es el único referente: todo y todos cambian sistemáticamente, y el espíritu del mesías renace cada cierto tiempo para intentar terminar la tarea inconclusa, llegar al fin de la historia: la eliminación de las clases sociales a través de la emancipación del proletariado.

La dinámica de la historia ha entremezclado los cambios de época con los retrasos de época: América Latina vive sus propios intentos revolucionarios a partir de aquellos contados en otras regiones, alejadas al continente, creyendo que las condiciones laborales, conjuradas entre las revoluciones industriales pueden, en concepto, extrapolarse a Latinoamérica, y creyendo que esta extrapolación es vigente y, aún más, extendida en el tiempo, como si existiere la necesidad de tener grupos revolucionarios permanentes, relegados unos por otros: breves y llenos de incertidumbre.

45 Augusto C. Sandino, a la libertad siempre. Taringa [en línea]. Disponible en: http:/ / www.taringa.net/posts / info / 11430674 / Augusto-C-Sandino-a-la-libertad-siempre. html 
Los retrasos de época dilatan los objetivos revolucionarios y mantienen vivo el romance, fresco y aún excitante. El romance hila fino sobre la dinámica de la historia y se cuece, cada vez con gran intensidad, sobre los jóvenes, siempre hambrientos, siempre deseosos de experimentar sus límites con cierta pasión. 


\section{Capítulo 3.}

\section{El Imperio y la Culpa}


Toda idea de revolución en Latinoamérica tiende a tener un discurso antiimperialista, agresivo y aún beligerante porque el discurso requiere de un enemigo, con preferencia un enemigo externo, cualquier país considerado como imperialista cubre bien esta necesidad. La estructura de pensamiento revolucionario en América Latina se construye por medio de una estructura de pensamiento común: la lucha de clases, el discurso marxista de la realidad. Para que el razonamiento revolucionario tenga coherencia, entonces, es indispensable la creación de un enemigo. Así, se requiere de un imperio que cumpla los elementos cognoscitivos de esta versión de la realidad: la presencia del imperio encaja en el asiento del acusado, con un juicio en proceso, empero, con la sentencia ya divulgada, ¡culpable! Al pensamiento revolucionario no le interesa saber si existen las pruebas suficientes, ni tampoco le interesa conocer versiones alternas: la sentencia es obvia, y no necesita de lecturas alternativas.

Latinoamérica pasó, a través de la emancipación de un colonialismo represivo, salvaje y esclavista, a un protectorado norteamericano que resalta y brilla por su presencia e injerencia en la región. La libertad encarnada en la creación de estados independientes abría la puerta a la necesidad de entender esta responsabilidad. Sin embargo, inmediatamente después de la emancipación del continente, la región se encontró con un nuevo actor político, uno que encajaría perfectamente el papel de enemigo externo, de imperio norteamericano. La burguesía se vía ahora encarnada en un sistema de protectorado. El argumento discursivo empezaba a ser claro: pasamos de un dueño a otro, sin reclamos o consultas, simplemente fuimos endosados de la colonia española al protectorado estadounidense. Los gritos de independencia no fueron gratuitos: libres del colonialismo español $\mathrm{y}$, sin espacio a la espera, nos encontramos anexados al protectorado de un nuevo Hegemón. El Tratado de París de 1898 daba inicio al protectorado estadounidense mientras el colonialismo español terminaba definitivamente en el continente. Mediante este tratado, España cede la posesión de Puerto Rico, las Filipinas, Guam, y Cuba a los Estados Unidos de Norteamérica: 


\section{Artículo I}

España renuncia todo derecho de soberanía y propiedad sobre Cuba. En atención a que dicha isla, cuando sea evacuada por España, va a ser ocupada por los Estados Unidos, los Estados Unidos, mientras dure su ocupación, tomarán sobre si y cumplirán las obligaciones que por el hecho de ocuparla, les impone el Derecho Internacional, para la protección de vidas y haciendas.

\section{Artículo II}

España cede a los Estados Unidos Ia isla de Puerto Rico y las demás, que están ahora baja su soberanía en las Indias Occidentales, y la isla de Guam, en el archipiélago de las Marianas o Ladrones.

\section{Artículo III}

España cede a los Estados Unidos el archipiélago conocido por las Islas Filipinas, que comprende las islas situadas dentro de las lineas siguientes $[\ldots]^{46}$.

La Guerra Hispano-Estadounidense recoge algunos de los deseos de independencia y libertad de Latinoamérica, aunque el conflicto realmente se desatara a causa de la explosión del acorazado Maine en las costas cubanas en 1898. El acorazado estadounidense entró a las costas cubanas sin aviso o permiso, en un intento soberbio de mostrarse como dueño del Caribe. Excusa o no, la carnada fue echada, y el pez picó, "en todas las probabilidades, el Maine fue destruido por un accidente el cual ocurrió dentro del barco [...] ¿Qué pasó? Probablemente un fuego en el bunker A-16. No hay evidencia que una mina destruyera al Maine" ${ }^{\prime 4}$. Años más tarde, aunque

46 Tratado de paz entre España y los Estados Unidos de América firmado en París el 10 de diciembre de 1898. Instituto de Investigaciones Jurídicas UNAM [en línea]. Disponible en: https:/ / archivos.juridicas.unam.mx/www/bjv/libros/6/2525/14.pdf

SCHOULTZ, Lars. Beneath the United States... Op. Cit. p. 138. Traducción hecha por el autor 
sin una completa seguridad de lo que realmente había pasado, se descartó que una mina haya destruido el navío. Sin embargo, la certidumbre que tenemos en el presente era completamente ajena al presidente MnKinley (1843-1901), quien inmediatamente pidió permiso al congreso estadounidense para empezar una campaña con una fuerte retaliación.

El hegemón no tuvo menos que declarar la guerra y tomar posesión de sus nuevos territorios. McKinley ordenó el bloqueo de Cuba el 22 de abril de 1898 y la intervención en otros territorios de la colonia española. En pocas horas tomó posesión de las Filipinas. Durante el mes de julio, los Estados unidos habían tomado posesión de toda la isla caribeña. El 12 de agosto se firma el armisticio obligando a Espala a renunciar a la soberanía de Cuba, Puerto Rico, las Filipinas y las islas Guam a los Estados Unidos. Hubo un único pago por la soberanía de las Filipinas, se desembolsó 20 millones de dólares ${ }^{48}$. Una vez tomada Cuba, McKinley anunciaba que serían los cubanos quienes dirigirían sus destinos, pero esto pasaría después de construir un ambiente de paz propicio. Lo que pasaría después resultaría en una sería de negociaciones entre la isla y los Estados Unidos que pondría en entredicho la independencia de la isla: Cuba se movilizaba entre el alejamiento de la colonia española a la aceptación sumisa de un protector regional: entre la bruma espesa de los recuerdos de la inquisición, a la idea de un nuevo protector, una guía con una imagen de aparente filantropía, con una imagen de un padre responsable.

Las primeras negociaciones entre Cuba y los Estados Unidos se contextualizaría dentro de los acuerdos de la Enmienda Platt. El retiro de la presencia del gran padre protector no vendría sin condicionamientos, el retiro del protector jugaría el papel de un padre distante pero dispuesto a intervenir cuando sea necesario. En 1901, la constitución cubana añadiría los requerimientos que propondría el hegemón para alcanzar cierta libertad, entre las siete condiciones, la más importante sería, quizá, el arriendo de tierras

48 Ídem, p. 141. 
para la creación de bases militares estadounidenses. La imagen del padre responsable no desapareció con la Enmienda Platt, sino que los acuerdos se consumaron como un espacio para una intervención con un propósito específico: los Estados Unidos podrían intervenir en la isla para mantener a un gobierno que proteja la vida, la propiedad y la libertad individual ${ }^{49}$. Así, el contexto de la intervención se construye como una fachada pintada con principios recogidos de la declaración de independencia de los Estados Unidos. En el tiempo, la fachada de la intervención empieza a deshacerse con la visión de una intencionalidad escondida: el control de la isla en tanto y cuanto la inestabilidad política juegue en contra del hegemón.

La intervención del hegemón en la isla se convierte en un nido de discursos anti imperialistas, en la excusa perfecta de la izquierda armada: la sobreprotección del nuevo padre de la región causó la rebeldía de la región. Las acusaciones se multiplicaban en el tiempo: ¿Quién lo colocó como padre de la región? ¿quién lo eligió como policías del mundo? Las respuestas recrean el ideal de insurgencia, la cual tenía resultados previsibles: las armas como única vía para librarse del vigilante regional. Así, la revolución encontró una sola vía posible, la única vía coherente con los ideales marxistas, la única vía posible que recreaba la idea de la lucha de clases: la revolución armada. La revolución se despierta de una manera violenta y virulenta, en una ráfaga de balas que ajusticien a los imperialistas y a los traidores de la patria y reclame su territorio como suyo, aunque no hubieren sabido que hacer en él, aunque no hubieren sabido cómo organizarse, aunque el caos surgido fuere peor que la colonia salvaje. Sin embargo, las ideas revolucionarias acogían la libertad como un escenario lleno de incertidumbres, lleno de ideales, lleno de fábulas: los revolucionarios conjeturaban dramas románticos para erigirse como los mesías políticos de la nación, para encontrase dentro de una conmoción social que los lleve al liderazgo del proletariado. No hay fatiga posible ni tarea imposible, el objetivo es el mismo: ajusticiar al imperio, culpable o no (no está en discusión), el debate de la revolución se centra en las formas de ajusticiamiento y en las reformas nacionales que alisen el camino hacia el socialismo.

Los Estados Unidos han venido construyendo su zona de

49 Enmienda Platt de 1901. Instituto de Investigaciones Jurídicas UNAM [en línea]. Disponible en: https:/ / archivos.juridicas.unam.mx/www/bjv/libros/6/2525/15.pdf 
influencia, y su imagen de culpabilidad ha crecido simultáneamente con su influencia, desde principios del siglo XX: en tanto y cuanto su expansión era evidente a través de la presión económica y política, el protectorado dio paso a la idea de insurrección. De la misma forma, la idea de imperio conlleva en sí misma la idea de revolución porque el imperio connota represión, brutalidad, explotación, mientras que la revolución connota sublevación, represalia, ajusticiamiento: la idea de revolución se convierte en el alter ego ${ }^{50}$ de la idea de imperio, la uno no puede existir sin la otra, la revolución pierde sentido sin la idea del imperio, o, en su defecto, de la burguesía. La esencia de la idea de revolución se difumina si la idea de imperio desaparece, por ello, la dependencia de una con la otra crece como una necesidad de supervivencia: sin el imperio, la revolución se configura en una idea impertinente, inadecuada, anacrónica, en un absurdo: con el imperio, la revolución toma vida, se fortalece, se engrandece, se convierte en la realidad ulterior.

En la creación del imaginario revolucionario, el ego juega el papel de un político conservador, represivo, abusivo, dispuesto a producir riqueza a través del último suspiro del proletario. Por otro lado, el alter ego juego el papel del revolucionario, lleno de ideales marxistas, dispuesto a tomar las armas, dispuesto a matar, dispuesto a consumir el imperio con fuego, en tanto y cuanto obtenga su valor más preciado, la instauración de un Estado socialista, la instauración de la dictadura del proletariado. La existencia de la idea del imperio, conlleva la existencia de la idea de revolución. En tanto y cuanto el imperio intervenga de forma violenta y proteccionista, la revolución reaparecerá con fuerza: a mayor intervención del imperio, mayor justificación para el nacimiento de la insurrección: la revolución no puede nacer sin la idea de su contrario, encarnado en la burguesía o en el imperio. La civilización, por lo tanto, obtiene dominio sobre el peligroso deseo de agresión del individuo al debilitarlo y desarmarlo y al establecer una agencia dentro de él para vigilarlo, como una guarnición en una ciudad conquistada.

50 FREUD, Sigmund. Civilization and its discontents. London: W.W. Norton \& Company, Inc., 1989. 
Dentro del discurso revolucionario, Latinoamérica, convertido en bastión geográfica, no tuvo menos que aceptar al nuevo Hegemón, no por opción o decisión posible, sino porque al nuevo monarca había que proclamarlo como tal, por conveniencia o impotencia, no importa, nos vimos parte del patio trasero por conveniencia o impotencia, esa no es la discusión, nos vimos parte de su protectorado. Era importante, para la ampliación de la influencia económica, a través del comercio, de construir un canal que conectase el océano Pacifico y el océano Atlántico. El presidente estadounidense Ulysses Grant (1869-1877) había creado una comisión especial para la creación de un canal que se erigiría en América Central, para el efecto, siete expediciones fueron enviadas para encontrar la ruta más apropiada. Grant había negociado con Colombia y, luego, con Nicaragua, la construcción del canal, sin embargo, la presión interna de ambos países coadyuvó a dejar de lado las negociaciones. Sin embargo, los Estados Unidos de América no eran los únicos detrás de la construcción de un canal, la región centroamericana también se encontró con la presión francesa, Lucien Wyse, oficial de la marina francesa, fue enviado a la provincia de Panamá, Colombia, para identificar una ruta apropiada. Wyse obtuvo la concesión del gobierno colombiano para construir y operar un canal que pasaría por el istmo de Panamá, “en mayo de 1876, Colombia otorgó una concesión para la construcción de un canal por parte de Panamá al teniente Lucien Napoleón Bonaparte Wyse, un oficial de la Armada francesa" ${ }^{51}$.

La respuesta estadunidense al desafío francés vino en forma de una fuerte respuesta: se ordenó el envío de navíos de guerra a las costas del Atlántico y Pacífico de Panamá. Con los navíos de guerra, se configura una nueva relación de la región: las dos vías posibles en la negociación o la intervención armada, si la una fracasa, la intervención siempre será un plan que esté en la mesa de alternativas. En 1880, el presidente Rutherfore Hayes (1877-1881) anuncia en el congreso que "la política de este país

51 FLEMING, Robert. Panama Canal Review. Official Panama Canal Publication [en línea], 2018. Disponible en: https: / / www.gpo.gov/ fdsys / pkg/GOVPUB-W79-75aa53832e40e 472df167aaade17a19f/pdf/GOVPUB-W79-75aa53832e40e472df167aaade17a19f.pdf. 
es un canal bajo el control americano [...] Los Estados Unidos no pueden consentir la sumisión del control a un poder europeo" 52 . Sin embargo, los Estados Unidos no estaban dispuestos a entrar en conflicto bélico con sus socios europeos. La solución a pareció en la mente de William Nelson Crownwell, prestigioso abogado, quien había trabajado en los Ferrocarriles Panameños, y había fundado la célebre firma de Wall Street, Sullivan \& Crownwell. Después de que los franceses se encontrasen con una bancarrota inesperada, los inversionistas franceses contratan a Crownwell para vender sus acciones in Nueva York. Crownwell se encontró con el desafío de convencer a los oficiales en Washington para hacerse cargo de la Compañía del Nuevo Canal de Panamá (el gobierno en Washington había desestimado la construcción del canal en Panamá, y se había proyectado para hacerlo en Nicaragua). El trato no era tan atractivo pues, aunque la tercera parte del canal ya estaba construido, el precio sobrepasaba las perspectivas estadounidenses. El gobierno terminó pagando \$40 millones de dólares estadounidenses (USD).

Aunque los diplomáticos colombianos y estadounidenses acordaron la construcción del canal en 1903, el acuerdo no satisfizo a la mayoría de parlamentarios colombianos. El acuerdo estipulaba que Colombia recibiría 10 millones de USD, seguidos de un pago anual de 250 mil USD. A Colombia se hubiese llevado 120 años obtener los 40 millones que los franceses habían obtenido por ceder sus derechos de construcción. Los parlamentarios colombianos rechazaron el acuerdo y conmocionaron las perspectivas estadounidenses. El nuevo Hegemón, en la necesidad de abrir paso para el comercio, ejerció su poder en la región tan rápido como pudo, a saber: en 1902, John Hay, Secretario de Estado de Theodore Roosevelt, negoció un tratado con Colombia negoció un tratado con el ministro de Relaciones Exteriores de Colombia, Tomás Herrán, en el cual Estados Unidos recibió permiso para construir un canal en Panamá, que en ese momento estaba controlado por Colombia. El Senado de los Estados Unidos aprobó este tratado, pero el

52 WILLIAMS, Charles Richard. Diary and letters of Rutherford Birchard Hayes. Columbus: Ohio State Archaeological and Historial Society, 1922, pp. 583-589. Traducción hecha por el autor. 
gobierno colombiano no lo hizo. Para la construcción de un canal en la provincia de Panamá, se pagaría 10 millones de dólares, y un pago anual de 250 mil dólares. La consecuencia de que el senado colombiano rehusará ratificar el tratado, fue que "Roosevelt dio apoyo clandestino a grupos que deseaban fomentar una rebelión en Panamá y separar la provincia de Colombia" ${ }^{53}$. El 6 de noviembre de 1903, el Departamento de Estado reconoce el nuevo gobierno de la República de Panamá. Finalmente, en 1914 se completó el Canal de Panamá.

La identificación del culpable, real o aparente, recurre al resentimiento, voraz y violento aliado, adictivo $\mathrm{y}$, a veces, ineludible compañero de la revolución. La revolución condena el intervencionismo, extensión de los tentáculos del Hegemón, y denuncia los intereses propios del imperio, sabiendo que sus argumentos resquebrajan la dignidad de los pueblos, juzgándolos ingenuos y mansos: "la gente de Sudamérica son los más ignorantes, los más fanáticos, lo más supersticiosos de todos los católicos romanos en el cristianismo" ${ }^{24}$. John Quincy Adams, sexto presiente de los Estados Unidos de Norteamérica. Así, es plausible pensar que la existencia de la revolución depende de la existencia de la idea de un culpable, sea este culpable real o aparente, no importa, la idea de culpable es indispensable para la existencia de la revolución. El culpable nunca dejará de ser culpable, la idea de revolución lo necesita. De igual forma, la revolución nunca dejará de abrazar la idea de mesías, no hay revolución sin mesías: la revolución necesita del culpable, pero también requiere la idea del mesías: no puede existir el héroe sin el villano.

Un caso que representa con claridad al villano se encarnizó en la United Fuit Company, multinacional estadounidense, dedicada a la explotación de frutas tropicales, sobre todo las bananas, en algunos países latinoamericanos. La exportación bananera era

53 SILOCKA, R. Empire Beyond the Seas. Teachers.yale.edu [en línea], 1978. Disponible en: $\quad$ http:/ / teachers.yale.edu/curriculum/search/viewer.php?id=new_ haven_78.03.07_u\&skin=h-print

54 SCHOULTZ, Lars. Beneath the United States... Op. Cit., p. 5. Traducción hecha por el autor. 
insignificante durante el siglo XIX, sin embargo, a finales del mismo siglo, su producción y exportación aumentaron de forma dramática, los estadounidenses consumían alrededor de 16 millones de manojos al año ${ }^{55}$. Durante las primeras décadas del siglo $\mathrm{XX}$, la United Fruit Company poseía 566 mil acres y empleaba a 15 mil personas en Guatemala. Juan José Arévalo, elegido presidente en Guatemala después de la llamada Revolución de Octubre en 1944, y su sucesor Jacobo Árbenz (presidente en 1950), se caracterizaron por el establecimiento de uniones y confederaciones laborales, por la implementación de un nuevo código laboral y por la reforma agraria. La reforma agraria de 1953 llevó a la expropiación del 40 de las tierras en posesión de la United Fruit Company.

Aunque el ataque a la United Fruit Company pareciera un problema de negocios privados con un gobierno, el gobierno estadounidense lo percibió como un ataque al sistema de libertades que encontraba su fundamento en el capitalismo y en la democracia: la expropiación de los bienes de la United Fruit Company se vería como un posible foco de expansión del comunismo, y terminación del sistema de libertades que emergía a través de la democracia. En palabras de John Foster Dulles, secretario de Estado (1953-1959) del presidente Dwight Eisenhower, incluso si la situación de la United Fruit Company fuese arreglada, incluso si recibieran una pieza de oro por cada banana, el problema sería el mismo, es decir, la presencia del comunismo en Guatemala. Ese el problema, no la United Fruit Company ${ }^{56}$. El reporte ${ }^{57}$ enviado por la Embajada de los Estados Unidos en Guatemala en 1947, presentaba el problema del comunismo como el elemento político más importante en Guatemala, un elemento que crearía inestabilidad a través del adoctrinamiento de ideas marxistas, las cuales presentan la realidad como una guerra entre clases sociales. En el mismo reporte se menciona el objetivo del gobierno de Guatemala de adoctrinar el pueblo a través de los programas de alfabetización: al mismo tiempo que aprendían el abecedario, aprendían sobre las ideas comunistas.

55 UNITED FRUIT COMPANY, web.mit.edu [online], 2018.Disponible en: http:/ / web.mit. $e d u /$ course / 21/21f704/UnitedFruit/UnitedFruit.html

56 DULLES, John News Conference. Washington. Department of State: American Foreign Policy 1950-1955, 8th june1954,

57 WELLS, Milton. Communism in Guatemala. : The Department's request for a report is Lovett to U.S. Embassy Guatemala, 1948. 
Por otro lado, la situación de Guatemala, vista a través de los lentes de la revolución, puso énfasis en las relaciones entre negocios e imperio: el imperio defenderá sus negocios alrededor del mundo, sea de forma diplomática, o sea de forma armada, para la revolución, los métodos del imperio son predecibles. Por ello, cuando los problemas de compañía fueron expuestos al gobierno del presidente Eisenhower, no se podía esperar menos que la intervención del gobierno estadounidense: en junio 1954 las Fuerzas Armadas estadounidenses, dirigidas por el coronel Carlos Castillo Armas, cruzaron la frontera guatemalteca y depusieron el gobierno. Estas políticas intentaron construirse con anticipación a la deposición del gobierno guatemalteco como un soporte estructural de las repúblicas americanas, quienes "en la Novena Conferencia de los Estados Americanos, declararon que el comunismo internacional, por su naturaleza antidemocrática y su tendencia intervencionista, es incompatible con el concepto de libertad"58, firmado en 1954, en la votación, México y Argentina se abstuvieron, mientras que Guatemala votó en contra.

La explosión del resentimiento causado por la intervención, sea esta justificada o no, sea esta por razones humanitarias, o por el esparcimiento del comunismo, o por cualquier otra razón, la intervención es vista como intromisión, las intenciones de cambios políticos se convierten en abusos del Hegemón, la negociación se convierte en imposición: la idea de protectorado cambia a la idea de colonia. Así, la presencia del imperio abre las puestas para el constante resurgimiento de las ideas de revolución: la revolución no muere, se reencarna de tiempo en tiempo, siempre con un nuevo enemigo, siempre con un nuevo propósito. La astucia de las ideas revolucionarias reestructura los nuevos movimientos sociales y les dota de razones que se confunden con los discursos. Las razones intentan recrear una plataforma de justificación, mientras que el discurso intenta alcanzar cierta idea de justicia o alcanzar cierto salvamento de la dignidad a través de la destrucción del enemigo,

58 SKLAR, Barry y HAGEN, Virginia. Caracas Declaration of Solidarity; March 28, 1954. U.S. Govt. Print. Off. Washington: Inter-American relations; collection of documents, legislation, descriptions of inter-American organizations, and other material pertaining to inter-American affairs, 1972. 
de la destrucción de la burguesía, de la destrucción del imperio. La injerencia directa, o manipulación indirecta del enemigo, reaviva el pulpo y sus tentáculos. No hay duda, las ideas revolucionarias se fortalecen a causa del mismo imperio: irónico y aún extraño, empero el mismo Hegemón ha construido con sus políticas la plataforma para que las ideas revolucionarias se multipliquen en el continente: la reacción es proporcionalmente directa a la intromisión.

La indignación consumada en el discurso provoca la generación de una burbuja de un pueblo rebelde: entre más grande la burbuja, más grande la percepción de descontento, entre más el tumulto, la idea de revolución se convierte en imperante. El discurso genera la movilización, y la movilización genera la idea de revolución, la cual regresa a la indignación. Así, el discurso empieza a pedir tribunales comunales, con la imagen de un pueblo comunitario, homogéneo, lleno de campesinos, indígenas, y todos aquellos considerados proletarios, quienes se han encontrado, de repente, elegidos como jueces $\mathrm{y}$, al mismo tiempo, han sido elegidos como audiencia, testigos y denunciantes. Los juicios comunitarios tienen un solo acusado, el imperio, y contienen un solo veredicto, culpable. El resto, pruebas o descargos a favor del acusado no serán tomados en cuenta porque la revolución no tolera ninguna forma de diálogo, es imposible pensar en el diálogo porque tal forma de relación con el enemigo confabularía la desaparición de la revolución: no hay revolución en el diálogo, no hay revolución en los acuerdos, no hay revolución en la democracia.

Así, cualquier forma de acercamiento con el culpable se confronta con una malla entrelazada de discursos agresivos. La tolerancia es contraria a la revolución, así como el diálogo o la misericordia hacia quien ha sido juzgado como culpable: la revolución es intolerante con todo intento de acercamiento, tómese el nombre que se tome, Alianza del Pacífico, Alianza para el Progreso, Tratados de Libre Comercio o Preferencias Arancelarias, the Andean Trade Promotion and Drug Eradication Act, ATPDEA, etc. No importa si las alianzas tienen el objetivo de erradicar la pobreza, de 
promover las exportaciones, o de combatir el narcotráfico. Nada de eso importa, lo relevante para la revolución es mantener la imagen de verdugo, con la mano en la cuerda que sostiene la guillotina, y con la cabeza del culpable rodando por la vereda. No importa de qué forma, todo intento de acercamiento es considerado como una potencial intromisión del imperio: los casos se repiten de manera sistemática, con diferentes matices, referentes y situaciones, empero el resultado es el mismo, la imagen del dominio hegemónico y el discurso de la resistencia revolucionaria.

La influencia del imperio en cada actividad y decisión de los países latinoamericanos conlleva a la creación de una imagen de sumisión frente al hegemón, generada alrededor de un discurso de presión, acuerdo o miedo, sin repararos más que los gritos de la conciencia revolucionaria, a veces acallada, otras reprimida, y en ocasiones condenadas al silencio. Los gritos de la conciencia revolucionaria se ven acallada por los acuerdos, por el progreso, por el diálogo, pero también se ven acallados por presiones, por el cuidado de que las ideas comunistas que suelen esparcirse velozmente. Así, no es extraño encontrarse con casos de presiones políticas o diplomáticas que intenten resquebrajar relaciones con países promotores del comunismo, eventualidad que no es aceptable en ningún caso ni bajo ningún pretexto: "las presiones para que el Dr. Velasco rompa con Cuba se hacían todos los días. El Embajador de los Estados Unidos, si no iba todos los días a visitar al Dr. Velasco lo hacía pasando un día para conversar y presionar sobre la ruptura" 59 . Dr. Manuel Araujo Hidalgo, ministro de gobierno ecuatoriano del Dr. Velasco Ibarra.

En el caso de Ecuador, el imperialismo ha dejado huellas marcadasen retratos bibliográficos, comoen testimonios. Recordamos a Philp Agee, ex agente de la CIA en Ecuador en la década de los 60s, quien mencionó en varias entrevistas y libros que durante su misión en Ecuador sus "agentes de la sociedad civil provocaron dos golpes

59 RODAS, German. La Argentina en la Segunda Posguerra y la Revolución Cubana. La década de 1960. En: RODAS, Germán. Cuba y Latinoamérica en los años 60. Quito: Ediciones La Tierra, 2009, p. 119. 
militares en tres años contra gobiernos civiles elegidos, mediante manifestaciones masivas y agitación civil" ${ }^{60}$. Aunque el relato deja de lado tomas los elementos sociales y políticos que recurren en una interpretación compresiva de los relatos históricos, si solo se toma en cuenta este dato extraordinariamente valioso, sabemos que los gobiernos derrocados en aquella época fueron el de Velasco Ibarra en 1961 y el gobierno de Carlos Julio Arosemena Monroy en 1963. Es solo dato, más allá de los contextos y variables sociales que puedan ser analizadas, ha abierto numerosos espacios para que la representación de la revolución en Ecuador sea moldeada, de forma continua, con insumos que reconstruyen el discurso desde la intervención de un país no invitado, desde la intervención del Hegemón. Así, la representación de la revolución sabe que su referente y misión ulterior es la independencia del imperio, para refundar lo fundado, y reconstruir lo construido: la revolución pretende rehacer todo de nuevo, las veces que sean necesarias, aunque se tenga que empezar de la nada cada vez, y aunque cada vez esto cree incertidumbre y caos.

En el tumulto constante de emociones antiimperialistas que recorren los espacios históricos, desde las intervenciones a principios de los nacimientos de la repúblicas latinoamericanas, hasta la burbuja de lo que conocemos como el Consenso de Washington, nacen los movimientos del socialismo del siglo XXI, con la Revolución bolivariana de Hugo Chávez a la cabeza y, como entenadas, la Revolución Ciudadana liderada por Rafael Correa en Ecuador, la Revolución boliviana liderada por Evo Morales, el Kirchnerismo, con Néstor y Cristina Fernández en Argentina, el Frente Sandinista de Liberación Nacional, liderado por Daniel Ortega en Nicaragua: revoluciones que han intentado jugar con los parámetros de la democracia, siendo reelegidos de forma constante en dudosas contiendas electorales, haciendo uso del aparato estatal como principal instrumento de propaganda, mientras se armó complicados sistemas de persecución a todo lo considerado como

60 FELDMAN, Bob, 2008, Phillip Agee: 1A CIA y la Financiación de las ONG - El Diario Internacional. Eldiariointernacional.com. Disponible en: http://www. eldiariointernacional.com/spip.php?article1742 
antirrevolucionario. Era común encontrarse con publicidad oficial que presentara a los antirrevolucionarios como los enemigos de la nación; era constante encontrarse con exámenes tributarios especiales a políticos $\mathrm{u}$ empresarios que alzaban su voz en contra de estos gobiernos; existe cada vez información más exacta de los sistemas de policía secreta que era utilizada para seguir los pasos de los opositores. Todos estos elementos nacen gracia a un punto de quiebre indispensable, la reconstrucción del aparato legal, haciéndolo transitar de un Estado de derecho a un Estado de poder autocrático: el poder autocrático tomó el nombre de Estado de derechos, pretendiendo elaborar un discurso de derechos, y dejando de lado la sumisión del poder al sistema legal. Así, estas naciones aprobaron nuevas constituciones, a través de mayorías favorables a sus objetivos: la maquinaria estatal ha refundado lo fundado y reconstruido lo construido, aunque esto involucre gastos ingentes $\mathrm{y}$ aunque estos pueblos hayan vivido este proceso en numerosas ocasiones (en el caso de Ecuador, se han redactado 20 constituciones).

Los movimientos revolucionarios han tenido cierto éxito en presentar la influencia del imperio como los tentáculos notorios del Hegemón, aunque éstos, en las últimas décadas, no crezcan con brusquedad. Durante las últimas décadas, los tentáculos del imperio crecen de forma diferente: crecen, se alimentan y se reproducen a través de convenios bilaterales militares. Bases militares que cooperen contra la lucha al narcotráfico, verbigracia, la Base de Manta en Ecuador, convenio firmado durante el gobierno de Jamil Mahuad en 1999. El convenio de la Base de Manta estipulaba que el propósito principal era intensificar la cooperación internacional para la detección, monitoreo, rastreo y control aéreo de la actividad ilegal del tráfico de narcóticos a que se refieren diversos instrumentos políticos y legales internacionales ${ }^{61}$. El convenio sirvió a las izquierdas para ofrecer una imagen diferente: la intromisión del imperio en asuntos de seguridad nacional. En el 2009, el presidente ecuatoriano, Rafael Correa, decidió terminar el convenio

61 PRESIDENCIA DE LA REPÚBLICA DE ECUADOR, 1999, Convenio de la Base de Manta. Sedici.unlp.edu.ar. Disponible en: http://sedici.unlp.edu. ar / bitstream/handle/10915 / 46431 / Ecuador_-_Convenio_de_la_base_de_ Manta_7_p._pdf?sequence $=2$ 
de forma unilateral, recordando los abusos del convenio, como el hundimiento de barcos pesqueros que trasladaban emigrantes hacia los Estados Unidos ${ }^{62}$. La terminación del convenio representaba la ruptura simbólica con el imperio: la intervención del hegemón quedaba relegada a los intereses de la Revolución Ciudadana.

La presencia de los Estados Unidos también se puede visualizar en las bases militares de Cartagena, Malambo, Palanquero, Tolemaida, Málaga, Apiay y Larandia en Colombia, firmados en el gobierno de Álvaro Uribe. Estas cooperaciones bilaterales han servido para construir una retórica de intromisión injustificable en territorios latinoamericanos. La presencia del hegemón representa la misma realidad, con diferentes actores, la intromisión del imperio. La revolución no tiene menos que oponerse a este insulto a la soberanía y, en uso de su brazo político llamado socialismo del siglo XXI, ha tratado de quebrantar estos tratados, sea por presión externa (como pretendieron hacer los líderes socialistas de América Latina con el gobierno de Álvaro Uribe en Colombia) o por uso del poder político justificado a través de un velo electoral. El imperio ha manifestado en reiteradas ocasiones que este asunto no revela problemas de soberanía, tal como lo sostiene William Brownfield, ex embajador de EE.UU. en Colombia: no es asunto de soberanía, sino de "colaboración entre dos países contra una amenaza compartida, la de la droga ilícita [...] No estamos hablando de una base militar en Colombia, sino de la posibilidad de acceso a las bases militares y navales de Colombia [...] en la medida en que Colombia acabe con el narcotráfico y el terrorismo se va a beneficiar a la región" ${ }^{\prime 63}$.

Las ideas de revolución, entonces, crecen proporcionalmente a la influencia hegemónica: a mayor influencia, mayor resistencia; a mayor presión, mayor subversión. Parecería paradójico y aún irónico:

62 CASA TIEMPO, 2018, Ecuador le pidió a Estados Unidos desalojar la base militar de Manta. El Tiempo. 2018. Disponible en: https://www.eltiempo.com/archivo/ documento/CMS-4417675

63 BIARDEAU, Javier, 2009, El eje Palanquero-Apiay-Marandúa: la trama oculta de las bases militares imperiales contra Venezuela I LaClase.info. Laclase.info. Disponible en: http: / / laclase.info/ content/ el-eje-palanquero-apiay-marandua-la-trama-oculta-delas-bases-militares-imperiales-c/ 
sin influencia no habría revolución, y sin revolución, las masas, aquellas esperanzadas en la venida del mesías, aquellas esperanzadas en la demolición de las jerarquías sociales, autodenominadas proletarias, se perderían en una suerte de crisis existencial, sin referentes ni razones, entre el caos y la insania, desolados y confundidos, buscando nuevos imperios o nuevas razones. Por ello, no es extraño encontrar a los nuevos enemigos en la prensa, en los empresarios, en todo lo que se relaciona con el capitalismo o con la libertad. La revolución no puede morir, ni esfumarse, el espíritu revolucionario siempre encontrará nuevos imperios, nuevas clases dominantes, nuevas razones: la resistencia se perenniza a manera de referente propio, en una dinámica tautológica, llegando a ser la fuente, el líquido, el bebedor y el retorno a la naturaleza. Así, la resistencia se encuentra desde el principio hasta el fin, sin límites y con varios protagonistas pasajeros, con apogeos y apagones transitorios, existencialmente renovables e imperecederos.

La revolución prefiere el caos de la libertad, mil veces libre y mil veces sola, antes que la alineación al estructuralismo del imperio, aunque esta involucre orden, bonanza, civilización: "la bendición de la civilización son todas buenas, y son una buena propiedad comercial; no podría ser mejor, en una tenue claridad [...] ¿Debemos proceder en contra de pueblos vecinos, donde una masacre sea reportada? ¿Podemos costear la civilización? ${ }^{64}$ - Mark Twain- ¡Cómo si tuvieren elección! Conjurados en una suerte de determinismo, aunque el imperio puede vivir sin la revolución, pero la idea de revolución no puede vivir sin la idea de imperio. El Hegemón puede vivir sin revolución, y puede definirse a sí mismo; sin embargo, la revolución no puede ser revolución sin la idea del imperio. La idea imperio amamanta la idea de revolución y empiezan a coexistir de manera sublime entre la insania y el sarcasmo, porque la subsistencia de la revolución depende de la existencia del enemigo, sea este, real o aparente. El circo de las revueltas requiere atraer al mismo público, en el mismo teatro, y con una misma entrada, porque la función no puede mostrarse sin el protagonista y el antagonista: la revolución no tuviere sentido sin la existencia de un imperio.

64 TWAIN, Mark, 1901, To the person sitting in darkness. Anti-Imperialist League of New York: New York. 
La revolución evoluciona sistemáticamente, con un objetivo fijo, el imperio, y con un camino invariable, el que recorra el imperio, donde este se mueva, la revolución irá por detrás y, donde existan nuevos hegemones, imperios, empresarios, prensa libre, etc. habrá nuevas revoluciones porque los procesos de cambio son perennes en el tiempo, con nuevos personajes y referentes, la revolución nunca termina, su existencia depende de la generación de nuevos enemigos. La revolución camina detrás del enemigo, sin variaciones ni distanciamientos. El imperialismo da vida a las ideas de revolución: las dos forman parte de una misma dialéctica móvil que parece no haber encontrado una síntesis adecuada a su contraposición, y parecen contraponerse con un único objetivo, seguir en movimiento: la revolución revive con cada imposición o se rejuvenece con cada intromisión hasta fortalecerse y quebrantar el equilibrio de poder. 


\section{Capítulo 4.}

\section{Conciencia Colectiva}


La conciencia colectiva de los revolucionarios ha definido la identidad de la revolución en una serie de eventos que han testificado su importancia histórica. Son los testigos de la revolución quienes conforman la conciencia colectiva de la misma, en una suerte de influencia presencial y sesgo ideológico, la personalidad de los personajes de la revolución se ha conjurado en una sola esfera colectiva y dinámica que reaparece de tiempo en tiempo. Así, la existencia de la revolución se ve afectada, o delineada, por las personalidades de los revolucionarios, algunos con ciertos rasgos de desequilibrio, manía, egocentrismo, otros con pretensiones de altivez, arrogancia, otros con rasgos de inmortalidad, y, todos, con un aura de mesianismo, con la idea de que la historia se acaba, no hay futuro después de la revolución, el fin de la historia se encarna en ellos. El mesianismo viene envuelto en versiones adornadas de procesos históricos, creando simultáneamente un sinnúmero de mitos y realidades que los adornan como héroes latinoamericanos, los postulan como deidades del materialismo: dioses sin Dios, mesías sin promesas proféticas. De esta forma, los líderes revolucionarios parecieran compartir características comunes que se contextualizan en ciertos principios, actitudes y argumentos: la conciencia colectiva de la revolución ha conformado un grupo con características endógenas y propias de Latinoamérica.

El mesianismo involucra la idea romántica de la muerte: no hay revolucionario sin muerte, porque no hay mesías sin sacrificio, si el sacrificio no existiese, la idea de mesías se difumina para convertirse en una imagen de un proletario aburguesado, de un dictador sangriento, de un enriquecido tirano. El caso de Fidel Castro nos lleva a pensar que su imagen se ha difuminado en el tiempo de la imagen de un revolucionario a la imagen de dictador, dispuesto a matar, mentir, o manipular para quedarse en el poder. Todo revolucionario sabe que es muy rentable quedarse en el poder, de hecho, en el 2006, la fortuna de Fidel Castro fue calculada en alrededor de 110 millones de dólares. Diez años más tarde, su fortuna alcanzaba una cifra cercana a 830 millones de euros. El revolucionario cubano se había convertido en una de las personas más ricas del planeta, "más rico que muchos reyes y con una fortuna similar a la de algunos 
sultanes"65. Por otro lado, la imagen del mesías que ha cumplido su misión se configura en la vida de Ernesto Guevara: dispuesto a morir en medio del combate armado. El romanticismo alrededor de la muerte de Guevara confluye la idealización del revolucionario.

La memoria que se construye alrededor de los revolucionarios se fundamenta en una personalidad característica a todos: "en una revolución se triunfa o su muere, si es verdadera" 66 , en la revolución no existe más de dos desenlaces, empero se contextualiza en una misma frase, “¡Patria o Muerte!”. Así, la memoria colectiva se fundamenta en un sistema dicotómico que restringe los argumentos a los medios necesarios para llegar al fin y, si esto no es posible, es mejor morir, sin metáforas o alegorías literarias, sino en la cruenta realidad que se enmarca alrededor de la muerte: no hay romanticismo en la muerte, pero sí en la idea de morir por la revolución, de manera que la muerte, grosera por naturaleza, se embellece en un romance noble, propia de todo relato novelesco, la muerte se encarniza en el personaje central de la historia, no hay relato romántico sin el protagonista, así como no hay mesías, sin muerte. ¡La muerte confirma el llamado! Sin muerte, la idea de mesías queda relegada a dos opciones: un nuevo renacimiento de un falso profeta; o, la personificación de la dictadura del proletariado, la cual no es momentánea, sino que tiende a extenderse en el tiempo, en tanto y cuanto el mesías siga vivo, la dictadura debe mantenerse.

La memoria de la revolución se construye en un complejo sistema de versiones y exageraciones, un mecanismo natural de cualquier movimiento histórico que se engrandece a través de su propia retroalimentación. Las ideas de revolución se trasmiten de generación en generación, cada versión con nuevos matices y con nuevas adaptaciones, de acuerdo a la época y al modo de ánimo cultural. Los recuerdos de esta memoria se trasmiten con base en las

65 DEL PINO, Andrea Rosa, 2016, Los 900 millones de herencia que, según Forbes, deja Fidel Castro. El Mundo [online]. 2016. Disponible en: https://www.elmundo.es/ loc/2016/12/02/58404ca122601dbb038b45c6.html

66 GUEVARA, Ernesto, 2007, Carta de despedida del Che a Fidel. Profesionalespcm.org: disponible en: http://www.profesionalespcm.org/conv/0710_Getafe_Actos_CHE_ PROGRAMA.pdf 
versiones de los protagonistas, las cuales se adornan y sesgan para que la muerte sea anhelada, y el desprecio sea honroso, para que la revolución este sobre todo sistema de creencias, como la religión o la familia, para que la idea de revolución parezca real, aunque ésta sea ilusoria: la revolución se embellece con cada nueva versión, y se reviste de fanatismo, en una suerte de dogma ideológico, dogma que, de tanto en tanto, se convierte en religioso: la fidelidad al nuevo reestructura la jerarquía de valores éticos, todo es ético en tanto y cuánto sea fiel a la revolución, en tanto y cuanto se fiel al revolucionario.

Durante los juicios de Núremberg, Hanna Arendt abre el espacio para entender como la maldad puede surgir de la irreflexión, como un acto de sumisión al Führer, un acto de lealtad al colectivo, el cual se fuerza a entrar a nuevo espacio de moralidad. La lealtad se convierte en el principal elemento de la nueva jerarquía de valores de movimientos colectivistas, entiendo el colectivo como primer fundamento de la sociedad, el cual deja de lado al individuo, el cual ha quedado relegado a las actividades del colectivo, "se necesitan de tres pautas que conducen a la dominación total: matar a las personas jurídicas de los individuos, la preparación de cadáveres vivientes en el asesinato de la persona moral de los hombres y la destrucción sistemática de la individualidad" ${ }^{\prime 67}$. La lealtad se convierte en el justificativo de la moralidad, la lealtad al líder revolucionario subvierte el resto de principios morales, sometiéndolos a un sistema de justificación: en tanto y cuanto la lealtad sea evidente, cualquier otro acto merece pasar por una construcción discursiva de justificación.

De esta forma, la construcción de aparatajes legales, bajo regímenes revolucionarios, nos lleva a considerar el riesgo inminente de formar reglamentaciones que favorezcan la lealtad al régimen, la lealtad al Führer mientras, al mismo tiempo, se justifique cualquier otro acto, sean estos: revisión de los ingresos económicos de periodistas, empresarios, políticos, etc; apropiaciones de la

67 HERNANDO, Esther. Hannah Arendt y la cuestión de la banalidad del mal. Universidad de Cantabria, 2016, p. 44. 
propiedad privada; encarcelamiento a toda persona considerada como contrarrevolucionaria; insultos, peyorativos, persecución comunicacional; $y$, en último caso, desapariciones forzadas. Todo es justificable dentro de la fidelidad, todo es cubierto por el humo de la sumisión. Si la sumisión se aplica a la ley, es evidente que ciertas acciones no son punibles, $\mathrm{y}$, sin embargo, son moralmente cuestionables $\mathrm{y}$, aunque actuar en contra de las leyes es un vicio, actuar a favor de esas leyes tampoco puede ser catalogado de virtud $^{68}$.

La lealtad es parte del éxito de la revolución, y cualquier fracaso es culpa del enemigo, sea esta culpa del imperio, los empresarios, los partidos políticos de derecha, la prensa, etc. Si la revolución fracasa lo hace como un fenómeno que requiere resurgir en medio de la presión del hegemón, en medio de las benevolencias de la democracia, en medio de las libertades del liberalismo. Si la revolución fracasa, la culpa siempre será del enemigo:

bestialidad que no tiene una frontera determinada, ni pertenece a un país determinado. Bestias fueron las hordas hitleristas, como bestias son los norteamericanos hoy, como bestias son los paracaidistas belgas, como bestias fueron los imperialistas franceses en Argelia. Porque es la naturaleza del imperialismo la que bestializa a los hombres, la que la convierte en fieras sedientas de sangre que están dispuestas a degollar, a asesinar, a destruir hasta la última imagen de un revolucionario... no se puede confiar en el imperialismo ${ }^{69}$. Ernesto Guevara.

La conciencia colectica se construye en una suerte de leyendas que resaltan el mesianismo como ente principal, el mesías es parte de la idea colectiva de revolución. La idea de mesías nos lleva a la construcción de mitos, apologías, cuentos o realidad exageradas,

68 KANT, Immanuel. La religión de los límites de la mera razón. Alianza Editorial, Madrid, 1985, pp. 45-48.

69 GUEVARA, Ernesto. Che Guevara, Imperialism speech 1965, translated. Disponible en: http:/ / www.youtube.com/watch?v=wdo6FwAPyng 
todas con una intencionalidad evidente: mostrar la valentía del mesías, un personaje dispuesto a ofrecer su vida, porque su muerte fortalece el mito, confirma la elección, cumple la profecía: todo mesías debe morir, sin muerte, el mito se desvanece en el tiempo, el mesías se convierte en dictador, y el ideal se convierte en un sainete. Así, la conciencia colectiva se fija en un concepto central, la representación del mesías como una divinidad que debe ser sacrificada: la relación con la historia del Cristianismo es evidente, $\mathrm{y}$, sin embargo, la una excluye a otra. En la revolución, el único mesías posible en el revolucionario, alguien dispuesto a morir por la imposición de un Estado socialista. Por otro lado, para que la idea de mesías funcione, se requiere de una masa convertida en discípulos, en una masa arraigada en la fe hacia el revolucionario, en una masa cuyo foco central de moralidad se encuentre en la lealtad. La revolución requiere del mesías, dispuesto a morir, pero también requiere de una masa sumisa, dispuesta a justificar cualquier acto, dispuesta a cubrir los errores, dispuesta a someterse a la difusión de mentiras, con el propósito de proteger la imagen del revolucionario. El romanticismo dual se entrelaza en la muerte del revolucionario y la lealtad de sus seguidores.

Uno de los claros ejemplos se confabula alrededor de la imagen de Salvador Allende, la imagen de un verdadero mesías, murió como un héroe, sin miedo ni perturbación, si no, más bien, en una actitud de coraje y templanza. La versión es impactante, sin embargo, quizá, simplemente se relata lo que se espera de todo revolucionario: la muerte antes que la claudicación porque la muerte es un privilegio más que un sacrificio. La muerte de Allende queda relegada a la versión de su amigo Danilo Bartulín: “Allende, con el casco puesto, estaba tranquilo, muy sereno, pero decepcionado [...] Los edecanes militares de La Moneda le dijeron: 'Mire, todas las Fuerzas Armadas están en el golpe, así que renuncie'. Él les responde: 'Ustedes pónganse a disposición de sus mandos, que yo me quedaré aquí como presidente' [...] ‘ YYo no voy a renunciar! Colocado en un tránsito histórico, pagaré con mi vida la lealtad al pueblo [...] tú has sido mi mejor y más leal amigo. Si quedo herido, pégame un tiro" ${ }^{70}$.

70 GUEVARA, Ernesto, 2008, Che Guevara, Imperialism speech 1965, translated. YouTube 
La actitud del personaje, asertiva e inmutable al extremo, perfila con delicadeza la actitud del revolucionario: ¡Revolución o Muerte!”.

La historia de la revolución enfatiza los recuerdos de sus mártires en un proceso diligente. Las versiones de los revolucionarios, divulgadas ampliamente, pretenden evocar memorias que generen nuevas insolencias contra el imperialismo: en 1966, la historia de Ernesto Guevara se escribe de una forma sui géneris, la idea de la revolución se intenta propagar por el continente latinoamericano, mientras se reinterpreta el papel dinámico del revolucionario, quien trasciende los hechos para erigir una leyenda, "toda nuestra acción es un grito de guerra contra el imperialismo y un clamor por la unidad de los pueblos contra el gran enemigo del género humano: los Estados Unidos de Norteamérica. En cualquier lugar que nos sorprenda la muerte, bienvenida sea"71. Ernesto Guevara entró a territorio boliviano para seguir su revolución en el continente, con objetivos claros empero con un desenlace imprevisto. Guevara fue herido en una pierna en Quebrada del Yuyo, trasladado a La Higuera y, en frente de agentes de la CIA, el Che Guevara fue ejecutado, dando, así, paso al mártir y al mito, el cual se constituyó en la imagen latente de toda revolución futura.

La existencia de una consciencia colectiva de la revolución involucra la existencia de una consciencia individual, sin la presencia de ésta última la memoria colectiva es imposible. La conciencia individual, la cual se construye a través de la trasmisión oral de las hazañas de los mártires, ha impregnado la revolución de manera que la historia se sesga de forma continua y se reconstruye, esta vez, desde la perspectiva de los revolucionarios, quienes han pretendido sesgar la revolución de manera que ésta es posible únicamente mediante de las armas: "yo no estoy dispuesto a entregar mis armas en caso de que todos lo hagan. Yo me haré morir con los pocos que me acompañan porque es preferible hacernos morir como rebeldes

[online]. 2008. Disponible en: http: / / www.youtube.com/watch?v=wdo6FwAPyng

71 AZNARES, Juan Jesús, 2006, Allende: “Si quedo herido, pégame un tiro". El Pais[online]. 2006. Disponible en: https://elpais.com/diario/2006/12/17/ domingo/1166331155_850215.html 
y no vivir como esclavos"72-Augusto Sandino. La referencia de las armas se relaciona con la revolución de manera intrínseca, en un sentido de pertenencia que se ha fortalecido durante el siglo XX. No había como pensar en movimientos revolucionarios sin la creación de grupos armadas, guerrillas que pretendían tomarse el poder a la fuerza, aunque varias de estas guerrillas encontraron su financiamiento en el narcotráfico. Los movimientos guerrilleros de izquierda se multiplicaron, y se hicieron populares porque la idea de lucha de clases se había impregnado en buena parte de sociedad, los ejemplos de la Unión Soviética, Cuba, China, etc. proponían una revelación utópica que requería trastornar el statu quo, requería revelarse en contra del capitalismo, en contra del liberalismo y su hijo predilecto, la democracia.

La imagen de las revoluciones comunistas se impregnó en la atmósfera de América Latina, sin saber, que estas revoluciones producirían en el mundo dictaduras sangrientas, con saldos impresionantes, alrededor de 100 millones de muertes ${ }^{73}$ si contamos solo las muertes de la Unión Soviética y de la China comunista. La dictadura de la Unión Soviética estuvo tan entremezclada con los regímenes de Cuba y China que sus sistemas educativos empezaron a dibujarse como un experimento compartido: los sistemas educativos en China y Cuba comunistas se establecieron bajo la influencia soviética. En China, el sistema educativo debía seguir cuidadosamente las experiencias desarrolladas en la Unión Soviética, los libros de texto soviéticos eran masivamente traducidos, mientras cientos de expertos soviéticos eran invitados a enseñar e incluso participar en la gestión escolar ${ }^{74}$. China adoptó la línea estalinista que insistía en las etapas universales de desarrollo desde la sociedad comunista primitiva hasta la esclavitud, el feudalismo, el capitalismo y el socialismo, independientemente de la falta

72 SANDINO, Augusto, 1927, Circular a las autoridades locales de todos los departamentos. Patria grande. Yali, Nicaragua, 1927.

73 RUMMEL, R. J., 1991, China's Bloody Century. New Brunswick, N.J.: Transaction Publishers.

74 CHEN, Yongfa, 2001, Seventy years of the communist Chinese Revolution. Taibei: Lianjing Publisher. 
de evidencia que respalde este marco de historia mundial ${ }^{75}$. Sin embargo, en 1957, Mao Tse-Tung demandaba que la educación de sistema chino debería estar al servicio de la política proletaria, y por ello debe ser integrada con el trabajo productivo, es decir, que los trabajadores sean intelectuales y, simultáneamente, los intelectuales deben también ser trabajadores ${ }^{76}$.

Cuba realizó grandes esfuerzos para acercarse al sistema educativo soviético, de hecho, Armando Hart, ministro de educación de Cuba viajó en 1961 Moscú y logró el apadrinamiento para la conformación de redes de cooperación. Esta cooperación permitió que el gobierno cubano enviará alrededor de cinco mil estudiantes a varios países de la Unión Soviética ${ }^{77}$. Unos pocos años después, en 1965, Fidel Castro decide cambiar la tonalidad de la educación, pasándola de a ser altamente basada en la transformación ideológica de cada ciudadano ${ }^{78}$. El objetivo primario de la nueva educación en Cuba debía obtener el adoctrinamiento ideológico. La creación de una conciencia socialista no se establece al azar, se construye en el adoctrinamiento, en la generación de un producto cultural dentro del cual sea natural ver el mundo como una constante lucha entre ricos y pobres, entre burguesía y proletariado, y ver que la única solución es el camino comunista.

La conciencia colectiva de la revolución plantea un dilema referente a la fiabilidad o inexactitud de la narración individual, o versiones sesgadas, de los actores, sabiendo que la historia debe ser documentada y valorada frente a los hechos contados desde varias perspectivas: el dilema de fiabilidad se convierte en un sistema dinámico en el cual se fundamentan las ideas de revolución. El

75 CHENG, Yinghong y MANNING, Patrick, 2003, Revolution in Education: China and Cuba in Global Context, 1957-76. Journal of World History [online]. 2003. Vol. 14, no. 3, p. 369. Disponible en: http://www.manning.pitt.edu/pdf/2003.RevolutionInEducation. pdf

76 MAO, Tse-Tung, 1967, Chairman Mao on Education Revolution. Beijing: People’s Publisher, p. 11.

77 JOLLY, Richard, 2019, Education: the pre-revolutionary background. En: Cuba: the economic and social revolution. Chapel Hill: University of North Carolina Press. p. 251.

78 CASTRO, Fidel, 1982, Fidel Castro on Chile. New York: Pathfinder Press, p. 56. 
dilema de la revolución es el dilema de los hechos contados por los sujetos, y es el fundamento de su tradición. Las ideas de revolución se fundamentan en un dilema de fiabilidad que muestra el sesgo de su tradición, empero, aún más importante, muestra también un valor restringido a su grupo, o limitado a los revolucionarios, de forma que la revolución es valiosa en tanto y cuanto sea percibida desde los revolucionarios, y es única en tanto y cuanto se construya sobre nuevos actores, aunque la trama sea la misma y la historia se repita con ciertas variaciones.

La conciencia de la revolución involucra la emancipación del proletariado del sistema capitalista y, por ende, del imperialismo, empero también involucra la idea de la dictadura del proletario como paso previo al fin de la historia, el cual se ha dibujado constantemente en el socialismo clásico, pero también se ha venido dibujando, durante el siglo XXI, en el socialismo del siglo XXI, el cual muestra una variante importante: el uso del sistema democrático de elecciones para llegar al poder. Estos nuevos movimientos del siglo XXI intentan recrear la conciencia colectiva de la revolución a través del juego democrático para llegar al mismo fin, la dictadura del proletariado. La tradición socialista se ha enfocado en los medios que resaltan las luchas armadas, sin embargo, el socialismo del siglo XXI se ha establecido como un nuevo movimiento político que ha encontrado su fundamento y justificación en un sistema democrático adornado con la auto determinación de los pueblos y con el apoyo de las masas: la dictadura del proletariado se pretende instaurar a través de las armas, si es posible, o a través de procesos electorales que forren la revolución con un velo democrático.

Se ha pretendido delinear el camino al socialismo a través de la dictadura del proletariado, en una suerte de marchitamiento gradual que debilitaría la dictadura, mientras se fortalecería el sistema socialista. No obstante, como lo menciona Mario Bunge31, la historia nos ha mostrado que las dictaduras no tienden a marchitarse, sino, más bien, tienden a fortalecerse, haciendo imposible el paso final al socialismo: los gobiernos autoritarios, en su pretensión de 
representar al proletariado, requieren de amplios discursos que intentan reflejar la necesidad del pueblo de mantener al dictador, de mantener al revolucionario en el poder. Las dictaduras no tienden a marchitarse, sino, más bien, tienden a perpetuarse en el poder en tanto y cuanto las masas lo justifiquen con el apoyo popular reflejado en los procesos electorales, "si ustedes lo quieren 11 años, dentro de 11 años yo tendré 66 (años) Dios mediante, y tendré 22 (años) de presidente" "En los otros 11 que vienen no quiero ni pensar porque ya serían 77 (de edad) y 33 (de gobierno). Ya es como demasiado tiempo"79 -Hugo Chávez.

De forma sucinta, entonces, podemos enlazar los cabos sueltos de la conciencia colectiva de la revolución para tratar de entenderla en su forma y fondo, sabiendo que los revolucionarios se enmarcan en sistemas psicológico-sociales similares, y sabiendo que la idea de revolución permanece igual, solo con pequeñas variaciones en los medios para empezarla, sea a través de las armas o de procesos electorales. Así, la revolución se construye mediante las versiones provenientes de los revolucionarios: cada versión, adaptada de acuerdo a la época y cultura, refleja la misma idea, "en una revolución se triunfa o su muere, si es verdadera", la revolución tiene dos opciones y se restringe a ellas en tanto y cuanto se esté dispuesto a morir. Además, la revolución necesita de una bestia imperial que justifique su existencia y determine su camino: no hay revolución si no hay imperio, la "naturaleza del imperialismo la que bestializa a los hombres, la que la convierte en fieras sedientas de sangre que están dispuestas a degollar, a asesinar, a destruir hasta la última imagen de un revolucionario" 80 . Por último, las revoluciones tienden a perpetuarse gracias a la dictadura de las mayorías, las cuales justifican su acumulación de poder, de manera que son las mayorías, o el proletariado, los que hacen de la revolución un movimiento político que tiende a perpetuarse. Estos cabos sueltos se entremezclan en la conciencia colectiva de la revolución en una

79 EL COMERCIO, 2010, Hugo Chávez cumplió 11 años en el poder y se quiere quedar otros 11 más. [online]. 2010. Mundo. Disponible en: http://archivo.elcomercio.pe/ mundo/actualidad/hugo-chavez-cumplio-11-anos-poder-se-quiere-quedar-otros-11mas-noticia-409175 
estructura de ideas extremas que tratan de proyectar su revolución perpetuamente. 


\section{Capítulo 5.}

\section{Seguridad Regional}


La tradición de las ideas de revolución no se conforma alrededor de un contenido político, alrededor de su andamiaje que pueda erigirse entre ideologías políticas: la tradición de las ideas de revolución dibujaba el camino como la constante búsqueda de la reimplantación de las estructuras estatales, empero, no sabía con claridad si el camino para hacerlo se dibujaba por la derecha, por la izquierda, centro, o algún camino alterno. Este camino fue encontrado de a poco, las opciones se fueron cerrando, mientras la angustia y el resentimiento de las masas revolucionarias habían encontrado una plataforma política en los brazos del socialismo. La vertiente de represión escondida en la conciencia colectiva se revela, ahora sí, con una ideología definida, con una plataforma específica, sabiendo, sin embargo, que el acercamiento al socialismo fue casual, no fue premeditado, ni pensando, sino que surgió como un bote salvavidas.

El surgimiento de movimientos revolucionarios, así como la lucha contra el comunismo, se someten a este juego de referentes: la definición se relega a la necesidad de un referente contrario, sin el cual, la definición sería ilusoria. Por un lado, la revolución necesita del imperio, del burgués, del enemigo: sin el referente contrario, la misma idea es ficticia. Por otro lado, el imperio no requiere de referentes contrarios, como lo hemos explicado anteriormente, sin embargo, su presencia alimenta la retórica de la sedición, alimenta el discurso de la sublevación: en tanto y cuanta la idea de imperio exista, la atmósfera de rebelión aparecerá de tiempo en tiempo. En esta dialéctica histórica, se entiende los continuos sucesos durante el siglo XX. El protectorado había empezado, mientras los protegidos, aturdidos o cegados, no sabían que ahora eran parte de una región con un solo guardián. Así, el protectorado resguardaría el mundo libre y el libre mercado en Latinoamérica, de una u otra forma: la rebelión en contra del mundo libre sería contactada, restringida y eliminada. Latinoamérica debía ser inmunizada de las ideas de comunismo, contrarias, en naturaleza, a la libertad del nuevo orden.

Nicaragua ha sido, para el hegemón, una constante ejemplificación de su política de seguridad, haciendo de Nicaragua, intencionalmente, un emblema para la revolución: José Santos 
Zelaya, dictador desde 1893 hasta 1909, acordó con los Estados Unidos la construcción de un canal interoceánico, sin embargo, finalmente, al resistirse, fue derrocado, marcando el inicio de una serie de intervenciones que finalmente desembocarían en una guerra civil cruenta al extremo. En tal conmoción, en la década de los 20, Augusto César Sandino se erige como líder campesino y organiza una milicia de campesinos y obreros, obligando al retiro de los marinos norteamericanos, quienes se habían hecho cargo de la administración política de Nicaragua. Sin embargo, estos no se retiran sin antes haber dejado a un amigo incondicional como jefe de la Guardia Nacional, Anastasio Somoza García, quién, rápidamente, programó la muerte de Sandino. Por iniciativa propia o por obediencia, Anastasio Somoza ejecutó al referente de la revolución, en un intento por eliminar la amenaza que este representaba: Augusto Sandino fue asesinado frente a un pelotón de fusilamiento el 21 de febrero de 1934. En poco tiempo, y progresivamente, "la familia Somoza, que para los años 40 no pertenecía a las más acaudaladas del país, fue aumentando su poderío económico hasta convertirse en un verdadero monopolio -1974 su fortuna se calculaba en 400 millones de dólares- el cual controlaba gran parte de la agricultura, el comercio y la industria" ${ }^{\prime 1}$. Estos eventos se delinean con la singularidad que se genera de la dinámica entre la revolución y el imperialismo: una dialéctica propia que ha provisto de sentido a las ideas de revolución, comunes en nuestro continente desde siempre.

De la misma forma, Carlos Castillo Armas, presidente de Guatemala, había ejercido una persecución institucional a todo grupo comunista, o con evidencia golpista, así, en 1957, Castillo es asesinado por un guardia del palacio, conocido por sus ideas comunistas. El guardia fue Romeo Vásquez Sánchez, quien después de ser abatido, debía recibir ese mismo día una postal de felicitaciones desde Moscú $^{82}$. En 1952, José Antonio Remón se convierte en presidente panameño, quien decidió estructurar la pesquisa institucional

81 GONZALES ARANA, Roberto, 2009, Nicaragua, dictadura y revolución. Memorias Revista Digital de Historia y Arquieología desde el Caribe [online]. 2009. No. 10, p. 231-264. Disponible en: https:/ / www.redalyc.org/articulo.oa?id=85511597009

82 ASOCIACIÓN DE INVESTIGACIÓN Y ESTUDIOS SOCIALES. Compendio de historia de Guatemala, 1944-2000, 2004, Guatemala. 
a todo movimiento comunista. Su acercamiento al presidente estadounidense Dwight Eisenhower llevaría al país centroamericano a arrendar el canal de Panamá y a suscribir, después del asesinato de Remón, el Tratado Remón-Eisenhower. El 2 de enero de 1955, José Antonio Remón fue asesinado en una ráfaga de balas en el palco presidencial de la casa Club, del hipódromo Juan Franco ${ }^{83}$. Sin saber con certeza los autores y motivos del asesinato, la muerte del presidente Remón trajo consigo una espesa bruma que escondía un juego sangriento entre los gobiernos latinoamericanos, cercanos a los gobiernos estadounidenses, y los movimientos revolucionarios.

Por otro lado, cuando Fidel Castro derroca el gobierno de Fulgencio Batista en 1959, Harry Truman, presidente de la unión americana entre 1945 y 1953, criticó duramente el bloqueo unilateral que Estados Unidos impuso sobre Cuba cuando Fidel Castro se perfilaba como dictador, arguyendo que, si él hubiere sido el presidente, le hubiere ofrecido ayuda a Castro con desarrollo económico, pero por supuesto, "este hijo de puta de Eisenhower fue tan tonto para ofrecer algo parecido" 84 . De las no existentes opciones, la revolución dibujó su sendero con un cincel que ha marcado el camino sin desviaciones ni bifurcaciones, la única ruta posible se completaba en una suerte de supervivencia, de manera que debía encontrar sus aliados donde pudiera y donde hubiera, así, se reinterpreta la historia en un sistema que se repetiría continuamente hasta llegar al socialismo de siglo XXI. Así, la revolución latinoamericana se aliará al comunismo porque no tiene otra opción: "Perón interpreta que el giro cubano hacia Moscú ha sido forzado por las circunstancias, por una suerte de realismo necesario para sobrevivir" ${ }^{\prime 5}$. Aunque este realismo involucre un canibalismo interno en contra de quienes son considerados burgueses, imperialistas o traidores de la revolución.

83 GARCÍA, Roberto y VALLARINO, Janette, 2016, 'Estos no son cohetes': el asesinato del presidente Remón Cantera y el lugar de Panamá en la ruta de las drogas heroicas. Revista Humanismo y Cambio Social. 2016. Vol. 3,

84 SCHOULTZ, Lars. Beneath the United States... Op. Cit., p. 355. Traducción hecha por el autor.

85 CRISORIO, Carolina. La Argentina en la Segunda Posguerra y la Revolución Cubana... Op. Cit., p. 26. 
La estrategia política estadounidense tenía en consideración la existencia de varios gobiernos inmaduros e inexpertos al momento de tratar con los movimientos comunistas: Nixon remarcaba que estos gobiernos son tan ingenuos que su actitud causa un abrumador temor ${ }^{86}$. La alternativa para jedar de apoyar a presidentes ingenuos se esgrimía en el apoyo a las dictaduras con la idea de que este apoyo lleve a la región de forma segura a la generación de gobiernos libres y democráticos. En retrospectiva, Milton Eisenhower, hermano del presidente norteamericano, Dwight D. Eisenhower (1953-1961), creía que en principio la política del gobierno estadounidense tenía sentido, sin embargo, en el tiempo, la decoración y apoyo incondicional a varios de estos dictadores desvió el propósito principal de la política gubernamental ${ }^{87}$. Cuando John FitzGerald Kennedy (1961-1963) se posesiona como presidente, la política estadounidense entraría en una nueva etapa, la etapa de la Alianza para el Progreso, la cual abriría la puerta para que el progreso, dentro de una democracia, sea valorado por encima de los ideales comunistas: por un lado, se mantenía la mano dura a través del apoyo a las dictaduras del continente; por otro lado, se intentaría abrir modos de desarrollo por medio del apoyo institucional a aquellos países de la región que lo requieran. El ejemplo más claro de la etapa de la Alianza para el Progreso se visibilizaría en El Salvador, por un lado, se fundó el programa Comida para la Paz con el propósito de alimentar a los pobres; por otro lado, se mantenía el programa de asistencia militar para detener cualquier aventura comunista.

La estabilidad de la región se veía entremezclada entre la protección militar contra el comunismo y la ayuda humanitaria para salir de la pobreza. Se enviaban convoyes llenos de comida, como llenos de oficiales militares: una forma sangrienta de jugar al policía malo y bueno. Entre la mano bondadosa y la mano dura del imperio, la oficina de Seguridad Pública de los Estados Unidos gastaba anualmente el $38 \%$ de su presupuesto solo para atender

86 NIXON, Richard, 1958, Minutes of National Security Council Meeting. Archivo impreso: FRUS 1958-1960, p. 240.

87 EISENHOWER, Milton, 1959, Report to the President: United States-Latin American Relations. Archivo impreso: Department of State Bulletin, p. 15. 
a la región latinoamericana a través de la creación de inteligencia contra insurgente ${ }^{88}$. En este contexto surge el caso guatemalteco: en 1954, el reciente elegido presidente, Juan Jacobo Árbenz Guzmán, fue derrocado por un golpe que tuvo el apoyo de la Casa Blanca. Árbenz había sido acusado de ser comunista y perseguir a los empresarios extranjeros. Jacobo Árbenz, presidente de Guatemala, inició un programa de expropiación y nacionalización de las tierras y de los bienes de producción, afectando a la United Fruit Company, la mayor propietaria extranjera de tierras, y cuyos accionistas fueron parte del gobierno de Eisenhower. Esta reforma se consideró un atentado en contra de la seguridad del mundo libre y se vio en la necesidad de intervenir: el Secretario de Estado, John Dulles, decidió cancelar los programas económicos de ayuda, y se decidió derrocar a Jacobo Árbenz. En 1954, tropas dirigidas por el coronel Castillo Armas, y apoyados por la CIA, invadieron Guatemala desde Honduras, Árbenz solo le quedaba renunciar al cargo, mientras se restituían las tierras a la United Fruit Company. Así, la seguridad o su versión del mundo libre, fue protegida nuevamente: "Los EE.UU. remplazó el gobierno de Guatemala elegido libremente con otra dictadura de derecha que vuelva a favorecer los deseos de la United Fruit Company" ${ }^{\prime 89}$. Su exilio terminó en México, en medio de un acoso constante por parte de la Agencia Central de Inteligencia, CIA $^{90}$. Después del golpe de estado, la ayuda de los Estados Unidos a Guatemala pasó de 464 mil dólares, en 1954, a 10,7 millones de dólares en $1955^{91}$.

Estos eventos nos llevan a considerar que la estabilidad de la región empezaba a construirse como una imagen utópica, amenazada por una constante coalición entre movimientos comunistas, muchos

88 BELL, David, 1964, Memorandum for the President. Archivo impreso: Confidential file, box 25 . Austin, Texas.

89 LANDMEIER, P., 1997, Banana republic: The United Fruit Company. Maya Paradise [online]. 1997. Disponible en: http: / / rozylowicz.com/pdf-files/banana-republic.pdf

90 GARCÍA FERREIRA, Roberto, 2006, La CIA y el exilio de Jacobo Árbenz. Perfiles Latinoamericanos [online]. 2006. Vol. 28, p. 59-82. Disponible en: http:/ / www.scielo.org. $\mathrm{mx} / \mathrm{pdf} /$ perlat/v13n28/v13n28a3.pdf

91 COMMITTEE ON FOREIGN RELATIONS, U.S. Senate, Mutual Security Act of 1955, 84th Cong. 1st Sess., Archivo impreso., p. 317. 
de ellos armados, y las dictaduras apoyadas por los Estados Unidos. A principios del siglo IXX, la Doctrina Monroe celebraba la existencia de un patio trasero que debía ser resguardado en toda circunstancia, aunque esto involucre la intervención directa en las conmociones internas y propias de cada país. La seguridad de la región era, entonces, responsabilidad del hegemón, no por petición, sino, más bien, por un sentimiento de compromiso: el gran hermano sentía la obligación de dirigir el continente por las vías de la democracia, intentando mostrar la perversidad inherente en las monarquías europeas durante las independencias de las repúblicas latinoamericanas $\mathrm{y}$, después, durante el siglo XX, para mostrar la malevolencia propia de todo sistema comunista. Después de la independencia de las repúblicas americanas, la Doctrina Monroe asume la responsabilidad ante el mundo por las deficiencias de las otras naciones americanas ${ }^{92}$. Al mismo tiempo, el esparcimiento de las ideas comunistas en el continente durante el siglo XX lleva a los Estados Unidos a considerar la responsabilidad de difundir sus valores con fuerza y amedrentamiento, como formas aceptadas para contrarrestar las ideologías socialistas que venían desde la Unión Soviética ${ }^{93}$. La Doctrina Monroe no solo prevendría al continente de caer en las manos del comunismo, sino que implantaría, a la fuerza si fuere necesario, las vías para la funcionalidad de la democracia.

Es indudable que la intervención de los Estados Unidos en América Latina también obedecía a una lógica de seguridad regional: la posibilidad de tener gobiernos comunistas en el mismo continente contemplaba el riesgo de encontrar focos de inestabilidad que amenazaría la seguridad del gobierno norteamericano y de sus aliados. La crisis de los misiles de 1962 se convertiría en el ejemplo más visible del emergente conflicto entre occidente y oriente, entre los Estados Unidos y la Unión Soviética: la influencia del régimen soviético en la región se mostraría como el intento de desestabilización del poderío estadounidense. En 1952 se crea la

92 INMAN, Samuel Guy, 1921, The Monroe Doctrine and Hispanic America. The Hispanic American Historical Review. 1921. Vol. 4, no. 4, p. 646. DOI 10.2307/ 2505682.

93 SABET, Shayda, 2019, US Foreign Policy in Latin America. E-International Relations Students [online]. 2019. Disponible en: https:/ / www.e-ir.info/2013/06/14/us-foreignpolicy-in-latin-america/ 
Junta Interamericana de Defensa (JID), que se definiría con la visión de una doctrina de seguridad nacional que requería de una cadena de regímenes militares en América Latina durante el período de la Guerra Fría ${ }^{94}$ : la JID dejaría de lado la gestión multilateral de la paz y la seguridad regional en favor del apoyo de grupos ad hoc, sean estos militares o civiles.

Además, la presencia del hegemón en la región configuraría una lectura basada en intereses: al imperio le interesa tener accesos directos a las fuentes de materias primas, como el petróleo, cobre, oro, etc. El interés por los recursos naturales de la región venía solapado por el juego de acercamiento democrático. Las estimaciones sobre los recursos naturales se registraban en los porcentajes de reservas de América Latina: $20 \%$ de las reservas mundiales de petróleo probadas y más del $4 \%$ de las reservas mundiales de gas. La mayoría de estas reservas están ubicadas en la Cuenca del Orinoco de Venezuela. Brasil, México y Ecuador también poseen importantes reservas convencionales de petróleo y gas: 10.2\% de las reservas de petróleo de América Latina. Bolivia, Perú, y Trinidad y Tobago tienen importantes reservas de gas convencional: $12.5 \%$ de las reservas de petróleo de América Latina ${ }^{95}$.

El hegemón recurrió, entonces, a una política de intervenciones para inmunizar a América Latina del comunismo, enmascarando sus políticas en discursos que buscaban la solidaridad del hemisferio para la contención a la expansión comunista, o de fuerzas militares soviéticas. La seguridad de la región estaba relacionada directamente con las amenazas del bloque soviético, las cuales podían variar desde amenazas militares hasta amenazas al mundo libre y su libre mercado. Sin embargo, la idea de revolución tiene una peculiaridad, su efecto dominó, que, enmarcado

94 BRIGAGÃO, Clóvis, 2011, Latin America: A Panorama of Security and Integration. En: Current Challenges for Disarmament and Peace Operations on the Political Agenda[online]. Rio de Janeiro. 2011. Disponible en: https://www.kas.de/c/document_library/get_ file?uuid=c85cb7de-b84d-c36e-19a3-5b63666ceba5\&groupId=252038

95 WALTER, MARTIN, 2006, Extractives in Latin America and the Caribbean. InterAmerican development Bank. Disponible en: https: / / publications.iadb.org/publications / english/document/Extractives-in-Latin-America-and-the-Caribbean-The-Basics.pdf 
en el comunismo, forma una bola de nieve que se desliza por la región, y crece con tal rapidez que en poco tiempo se vierte por toda América Latina. La expansión de la revolución comunista quebrantó el balance de poder y generó nichos de inseguridad internacional, construyendo espacios que confluyeron en el Guerra Fría. Así, la Revolución cubana produjo un efecto dominó en latinoamericana, calamitoso para algunos, peligroso para otros, y, para unos pocos, el comunismo llegaba como el camino a la salvación de la región: “Ud. Tiene una fila de dominós colocados, golpeas el primero, y lo que le va a pasar al último es la certidumbre de que pasará muy pronto. Así era conceptualizado Latinoamérica hasta el fin de la Guerra Fría, como una fila de dominós cuya inmadurez política facilitaba la expansión comunista" ${ }^{16}$-Dwight Eisenhower.

La seguridad pareciera entrar en un juego de percepciones y miedos, algunos necesarios, y otros irracionales, empero todos, sin divisiones ni términos, se conjugaron en la misma cacería de fantasmas, algunos reales, y otros imaginarios, unos con intenciones peligrosas y expansionistas, y otros en una coyuntura local y ocasional: el comunismo se moldeó como la amenaza más grande para la región latinoamericana, y los "Estados Unidos planteó como un problema de seguridad nacional cualquier insurrección o levantamiento de tipo nacionalista o comunista que significase una potencial amenaza para el mundo libre" ${ }^{\prime 7}$. Así, la seguridad regional pareciera entremezclarse o confundirse con la seguridad del hegemón, convencido o confundido de que el mundo libre es el mundo del hegemón, y que la paz del mundo o de la región debe protegerse de toda amenaza comunista.

El período post Segunda Guerra Mundial languideció la relación entre la región latinoamericana y los Estados Unidos. Este

96 SCHOULTZ, Lars. Beneath the United States... Op. Cit., p. 343. Traducción hecha por el autor.

97 CARBONE, Valeria Lourdes, 2014, Cuando la Guerra Fría llegó a América Latina... La Política Exterior Norteamericana hacia Latinoamérica durante las presidencias de Eisenhower y Kennedy (1953-1963). Centro Argentino de Estudios Internacionales. Programa Historia de las Relaciones Internacionales [online]. Disponible en: https:// www.academia.edu /2567374/_Cuando_la_Guerra_Fr\%C3\%ADa_llegó_a_América_ Latina..._La_Pol\%C3\%ADtica_Exterior_Norteamericana_hacia_Latinoamérica_ durante_las_presidencias_de_Eisenhower_y_Kennedy_1953-1963_ 
alejamiento compuso emociones encontradas, el gran hegemón, posesionado por sí mismo como protector de la región, había tornado su mirada a Europa, desdeñando las necesidades de su Backyard. Por un lado, el gran hermano había decidido atender a regiones separadas del continente; por otro lado, la cierta libertad tomó caminos que la acercaban de a poco a las ideas comunistas. La realidad europea requería toda la atención de los Estados Unidos; sin embargo, al mismo tiempo, esta atención dejó escondrijos para que la influencia soviética se filtrara y generara ideales utópicos a través de la subversión y resquebrajamiento de la estructura de las democracias liberales. Aunque el hegemón intentaría abrazar los dos frentes, Europa y América Latina, la tarea se hizo insoportable. El Plan Marshall se ideó como un plan de ayuda para la reconstrucción de Europa Occidental, a cambio de un control sobre la expansión comunista. Los Estados Unidos intentaban posesionarse como el líder mundial en Europa y América, desafiando a todo el bloque comunista. De esta forma, mientras América Latina vio con asombro la ejecución del Plan Marshall, aturdida entre el protectorado y el acercamiento marxista, el mundo occidental estaba siendo infiltrado por la presencia comunista. La región encontró demasiados escondrijos para apreciar al comunismo y acogerlo como propio. Esto produjo que los conflictos entre los dos bloques existentes, U.R.S.S. y EE.UU. se trasladasen a las colonias o protectorados y, en el caso de Latinoamérica, el conflicto se agrandase rápidamente a causa de la existencia de movimientos revolucionarios latinoamericanos que daban la bienvenida al utópico marxismo.

La estrategia que dio buenos resultados en Guatemala sería nuevamente utilizada en Cuba, sabiendo que la revolución del régimen castrista había empezado por quebrantar los intereses comerciales norteamericanos en la isla (la reforma agraria se concentró en la nacionalización y expropiación de todos los bienes de producción extranjeros): la seguridad del mundo libre estaba siendo amenazada nuevamente y el hegemón, convertido en cegatón, por decisión más que por inhabilidad, sin poder ver otras alternativas reales para la defensa del comunismo, decidió actuar, esta vez, indirectamente. En 1961, los Estados Unidos organizaron 
entrenamientos de cubanos disidentes para una invasión a la isla, más de mil exiliados cubanos irrumpieron en las playas de Bahía de Cochinos con la intención de iniciar un levantamiento que derrocaría al gobierno de Fidel Castro ${ }^{98}$. En 1960, oficiales de la CIA viajaron a Miami, Florida para entablar acercamientos con miembros del Frente Revolucionario Democrático (FRD), un grupo activo de exiliados cubanos que habían huido de Cuba. Se reclutó a 1.400 personas. Recibieron entrenamiento en armas, tácticas de infantería, navegación terrestre, tácticas de asalto anfibio, operaciones de guerrilleros en equipo y paracaidismo. Existe la alta probabilidad de que algunos de los reclutas eran agentes dobles, que trabajaban en conjunto para Castro, compartiendo la información que habían recopilado sobre la próxima invasión ${ }^{99}$. En menos de 48 horas, la invasión fracasó. Año y medio después, "en un momento álgido de la crisis, Fidel Castro mandó una carta a Nikita Krushev, recomendándole que, en caso de que Estados Unidos invadiera Cuba con tropas convencionales, la Unión Soviética debería tomar la iniciativa lanzando un ataque nuclear contra Estados Unidos"100.

La seguridad de la región llegó a un éxtasis en lo que se conocería después como la Crisis de los Misiles. Los convenios entre Cuba y la U.R.S.S. debían dar fruto en una alianza militar, así, la U.R.S.S instaló bases de misiles balísticos en Cuba, mientras los Estados Unidos tenían un escudo de protección y ataque en Turquía. Un tenso ambiente político y militar se generaría durante 13 días en octubre de 1962 por la instalación de misiles soviéticos con armas nucleares en Cuba, a solo 90 millas de las costas de los EE. UU. El 14 de octubre, después de que el piloto de un avión espía U-2 estadounidense, aviones norteamericanos, a través de fotografías, descubrieron la existencia de las bases de los misiles soviéticos. El

98 FALCÓN, Manuel, 1993, Bay of Pigs and Cuban missile crisis: presidential decision-making and its effect on military employment during the Kennedy Administration. Leavenworth, Kansas: Tesis de Maestría en Arte y Ciencia Militar.

99 LOCKHART, James, 2016, Spy vs Spy: The Bay of Pigs and the battle for the soul of the CIA. War on the Rocks [online]. Disponible en: https: / / warontherocks.com/2016/12/ spy-vs-spy-the-bay-of-pigs-and-the-battle-for-the-soul-of-the-cia/

100 RODRÍGUEZ, Jorge, 2001, Cuba y la eterna Guerra Fría. Foreign Affairs en Español [online]. Vol. 1, no. 3, p. 30. Disponible en: http://www.people.fas.harvard.edu/ jidoming/ images/jid_cuba.PDF 
16 de octubre se informó al presidente Kennedy sobre la situación, e inmediatamente convocó a un grupo de asesores. Las deliberaciones se prolongaron durante una semana, al final, se presentaron una variedad de opciones, que incluían un ataque con bombas en los sitios de misiles y una invasión a gran escala de Cuba. En una transmisión televisiva realizada el 22 de octubre de 1962, el presidente Kannedy notificó a los estadounidenses la presencia de misiles, explicó su decisión de ordenar el bloqueo marítimo de la isla. Después de varios días de intensas negociaciones y tensiones "Kruschev, el segundo -sin consultar antes con Fidel Castro- aceptó retirar los misiles y desistir de utilizar a la isla como base de operaciones de armas nucleares, a cambio de la promesa de Kennedy de remover los mísiles que tenían localizados en Turquía y de la promesa de no invadir Cuba ni apoyar otra invasión anticastrista que pretendiese derrocar al gobierno de Castro" ${ }^{\prime 101}$.

En 1970, los Estados Unidos, a través de su asesor de seguridad, Henry Kissinger, definieron a Chile como un caso de seguridad que merecía una atención extrema. La elección de Allende como presidente marcó un enclave en la historia de la revolución socialista al verse legitimada por un sistema democrático que se vislumbraba como un sistema muy ajeno a la naturaleza misma de la revolución, y muy ajeno al proceso dialéctico de la lucha de clases: la democracia socava los fundamentos del socialismo clásico, sustituyendo la lucha de clases por un proceso electoral, y la dictadura del proletariado por un presidente autocrático. Inmediatamente, Richard Nixon ordenó el bloqueo económico de Chile y "el 15 de septiembre de 1970 Nixon exigió a la CIA hiciera aullar a la economía chilena"102 "Nixon insistió en que Estados Unidos debía arruinar drásticamente la economía chilena"103. Allende se convirtió rápidamente en un personaje trascendental que debía ser silenciado: la seguridad del mundo libre debía resguardarse en Chile. Así, el golpe de estado acaece en una

101 CARBONE, Valeria Lourdes, 2014, Cuando la Guerra Fría llegó a América Latina... Op. Cit., p. 15.

102 AMORÓS, Mario, 2000, La CIA contra Salvador Allende. Centro de Estudios Miguel Enríquez. Historia Político Social-Movimiento Popular [online], p. 4. Disponible en: https: / / www.archivochile.com/S_Allende_UP/otros_doc/SAotrosdoc0008.pdf

103 Ídem, p. 2. 
serie de sombríos rumores acerca de la muerte de Allende: algunos testimonios revelan el asesinato cruento de Allende durante el asalto al Palacio de la Moneda, pretendiendo embalsamarlo como mártir de la revolución, mientras otras versiones relacionan su muerte con un suicidio abrupto, construyendo la figura de un líder temeroso. Así, Chile, bajo la dictadura de Augusto Pinochet, se alineó al mando del hegemón y su imagen se construyó bajo un nuevo concepto para América Latina, el neoliberalismo, mientras la percepción de seguridad se edificaba bajo el miedo de intervenciones futuras.

Pocas décadas después, nos encontramos con un nuevo movimiento socialista que surge desde una cierta institucionalidad democrática y que generó nuevas incertidumbres a la seguridad de la región: el socialismo del siglo XXI surge en América Latina como un movimiento revolucionario que se ha tomado el poder desde los procesos electorales, y se ha cubierto de un velo democrático a través de la popularidad de sus gobiernos. Los gobiernos latinoamericanos del nuevo socialismo se han convertido en el nuevo escollo para la perspectiva de seguridad que maneja el hegemón, y han revivido algunos fantasmas del comunismo de la Guerra Fría. Las Revoluciones bolivarianas dibujaron nuevos íconos en la historia de la revolución, empero con las mismas ideas y reformas, estructurados con pequeños cambios, como si el tiempo se hubiere bifurcado en el mismo espacio, haciendo de las revoluciones del socialismo del siglo XXI copias adaptadas de las revoluciones del siglo pasado. Uno de los casos más complejos fue el conflicto entre Ecuador y Colombia en marzo de 2008. Este conflicto pudo haber causado intensos enfrentamientos militares que despejaban un problema aún más profundo, el impacto ideológico de las narcoguerrillas en estos nuevos regímenes socialistas.

El 1 de marzo de 2008, la fuerza aérea colombiana atacó el campamento clandestino de las Fuerzas Armadas Revolucionarias de Colombia (FARC) en una remota región del noreste de Ecuador, matando a su líder, Raúl Reyes, y otras 24 personas. Las FARC habían estado utilizando el territorio ecuatoriano durante años 
para descansar y reabastecerse. El ataque fue exitoso, pero detonó la peor crisis en la diplomacia interamericana de la última década. Para Colombia, el ataque demostró el nuevo profesionalismo de sus fuerzas armadas y la policía y el éxito continuo de la estrategia de seguridad democrática enunciada por el presidente Álvaro Uribe. Además, señaló los notables avances logrados por Bogotá en la búsqueda de las FARC, en la reducción del alto nivel de inseguridad que ha dominado el país durante una generación, y el aumento en el alcance y la presencia del gobierno en áreas fuera de su control. El ataque fue inmensamente popular dentro de Colombia, que ahora comenzó a ver la luz al final del túnel al derrotar a las FARC. Además, la muerte de Reyes fue una de una serie de pérdidas de comandantes de alto nivel.

Dentro del Ecuador, la historia fue marcadamente diferente. Pocas horas después del ataque, el gobierno del presidente Rafael Correa fulminó a Uribe, iniciando así un feroz asalto diplomático que duraría meses, llevaría a la retirada de embajadores y traería a la Organización de los Estados Americanos. Por varias razones, Ecuador se sintió victimizado. En primer lugar, estaba experimentando un proceso político particularmente difícil para tratar de reforzar un Estado deficiente dividido por la polarización política y la amenaza de violencia. En segundo lugar, un alto nivel de corrupción había debilitado las instituciones del Estado. Tercero, Ecuador no tenía la capacidad de asegurar su frontera con Colombia. A pesar de que su ejército estaba desplegado extensamente en la frontera, carecía de la logística para hacer frente a la amenaza. Cuarto, en 2000 Ecuador asumió una postura poco realista de neutralidad con respecto al conflicto interno de Colombia. En quinto lugar, para agravar estas contradicciones, Ecuador adoptó una postura antagónica en su cooperación con los Estados Unidos para contrarrestar el movimiento de narcóticos ha sido muy útil.

Las lecciones de la crisis del 1 de marzo son fundamentales para la cooperación de seguridad en el hemisferio. La crisis se superpone a una tradición latinoamericana de laissez faire sobre 
el espacio no gobernado y el control de las fronteras y el continuo desacuerdo sobre qué hacer con el terrorismo. Además, la capacidad institucional, la voluntad política, la diplomacia preventiva y los mecanismos para la cooperación de seguridad y la resolución de conflictos entre los Estados no han alcanzado las demandas de las guerras sin fronteras. Un surtido de terroristas, contrabandistas y narcotraficantes dependen de fronteras débiles y estados débiles. Aunque Clausewitz pudo haber tenido razón en que la guerra es la continuación de la política por otros medios, la política de las guerras sin fronteras ha cambiado esa ecuación. Sin embargo, las capacidades analíticas e institucionales de los gobiernos no han alcanzado ese cambio.

Los Estados Unidos pueden y deben ser un catalizador para el fomento de la confianza entre Ecuador y Colombia con el fin de restaurar la gama completa de la cooperación de seguridad entre los dos países. Al mismo tiempo, los Estados Unidos deben ser más sensibles al inmenso poder que ejerce en sus relaciones con los estados pequeños, como Ecuador. En los últimos 10 años, los Estados Unidos no han respondido a las necesidades de seguridad de Ecuador, en ocasiones por las más nobles intenciones. Las nobles intenciones pueden tener un profundo impacto negativo si la política no se aplica de manera pragmática.

La lectura de estos nuevos movimientos socialistas no se simplifica al temor del renacimiento del comunismo, sino a la carrera armamentista que fluye conjuntamente: "el primer ministro de Rusia, Vladímir Putin, firmó con el presidente Hugo Chávez 31 acuerdos... Rusia se ha convertido en el principal proveedor de armas para toda la región desde 2009... Desde 2005, Venezuela ha comprado armamento ruso -aviones, helicópteros y fusiles Kaláshnikov, entre otro material bélico- por un total de $\$ 4.000$ millones USD"104. Sin embargo, los gobiernos del nuevo socialismo latinoamericano, el denominado "socialismo del siglo veintiuno",

104 FREITAS, Manuel, 2010, Alianza energético-militar: Chávez y Putin desafían en el Patio Trasero. IAR Noticias [online]. Disponible en: http: / / www.iarnoticias.com/2010/ secciones/latinoamerica/0020_alianza_putin_chavez_03abr2010.html 
no tuvieron la misma prioridad de seguridad nacional para el presidente Obama, de hecho, varios intelectuales recrudecieron su crítica ante la pasividad del gobierno estadounidense frente a los atropellos a las libertades democráticas que se iban multiplicando en estos países: estos países rápidamente se convirtieron en una zona de influencia que amenazaba la seguridad de la región. Carlos Alberto Montaner denunciaba el absurdo de los ocho años de aislamiento del régimen de Barack Obama de América Latina, “¿qué sentido tiene que Estados Unidos -y con él la Iglesia católica- contribuya al fortalecimiento de un Capitalismo Militar de Estado, enemigo de las libertades, incluidas las económicas, violador de los Derechos Humanos, que perpetúa en el poder a una dictadura colectivista que ha destrozado a Cuba y hoy contribuye a destruir a Venezuela porque no puede enseñar otra cosa que lo que ha hecho durante 56 años?". ${ }^{105}$

Aunque el imperio siempre fue acusado como un país intervencionista, su política con relación a la región latinoamericana ha pasado por sombras y claros, con claros ejemplos de influencia y, con sombríos momentos de indiferencia, al menos, eso se presume: “El ex presidente de Estados Unidos, Jimmy Carter (1977-1981), opinó que su país pudo haber estado involucrado o haber tenido pleno conocimiento del fallido golpe de Estado del 2002 contra el mandatario venezolano Hugo Chávez... Creo que no hay duda alguna de que, en el 2002, Estados Unidos tenía al menos pleno conocimiento o pudo estar directamente involucrado en el golpe"106. El regreso de la mirada del hegemón al problema del socialismo del siglo XXI, acaeció en el gobierno de Donald Trump, quien reconoció en Cuba y Venezuela puntos focales de inseguridad: las dos naciones se convirtieron en los paraísos del narcotráfico, y, en caso de Venezuela, se convertiría además en el paraíso de los grupos guerrilleros.

105 MONTANER, Carlos Alberto, 2015, Obama y los Castro. El País [online]. 2015. Columnistas. Disponible en: https://www.elpais.com.uy/opinion/columnistas/ carlos-alberto-montaner/obama-castro.html

106 DIARIO EL UNIVERSO, 2019, Carter implica a EE.UU. en golpe a Venezuela y critica a Chávez. Guayaquil, 21 de septiembre. 
Durante el gobierno del presidente colombiano Álvaro Uribe Vélez, el embajador ante la OEA, Luis Alfonso Hoyos, denunció la presencia de 1.500 guerrilleros en territorio venezolano, divididos en 87 campamentos, su petición fue contundente, "esperamos que Venezuela coopere y que además cumpla con las normas internacionales y nacionales, no se puede permitir la presencia de este tipo de grupo en ningún estado que estén realizando todas estas actividades delictivas"107. La denuncia vino marcada de coordenadas, fotografías, testimonios y denuncias de que cuando los jefes guerrilleros salen de sus campamentos, son escoltados por el ejército de la República Bolivariana de Venezuela, incluso se denunció las coordenadas en las que estaría viviendo el comandante del ELN, Carlos Marín, alias Pablito, quien se fugó de territorio colombiano en 2009. El mismo día, el presidente Hugo Chávez, acompañado por el futbolista Diego Maradona, en una alocución pública, rompe relaciones diplomáticas con Colombia. La denuncia no continuó con la fortalece inicial dado que, unas pocas semanas después, la presidencia de Colombia pasaría a manos de Juan Manuel Santos. Las evidencias encontradas años después, durante la dictadura de Nicolás Maduro, reafirmaría la denuncia hecha en el 2010.

Así, la historia pareciera repetirse con bastante frecuencia y con algunas mutaciones, empero el principio sigue intacto: la conservación de la seguridad y del mundo libre, desde la perspectiva del liberalismo, los principios democráticos serán guardados por cualquier medio y a cualquier costo. La idea de seguridad se contrasta con las ideas generadas alrededor de las revoluciones latinoamericana, en una suerte de eventos históricos que se repiten con frecuencia y con cierta similitud, formando una especie de juego dialéctico, basado más en intereses coyunturales que en fuerzas ideológicas, y haciendo de la revolución la antítesis de la democracia. Sin embargo, la revolución y la democracia se habían conjurado para resurgir en un nuevo movimiento socialista, en el

107 MORALES, Isabel, 22 de julio de 2010, Colombia denuncia ante OEA que 1,500 guerrilleros se refugian en Venezuela. Nuevo Herald [online]. Disponible en: https://www. elnuevoherald.com/noticias/mundo/america-latina/venezuela-es/article2006989. html 
socialismo del siglo XXI, construyendo un nuevo proceso dialéctico, quizá más difuso que el anterior, porque el nuevo socialismo había sido justificado a través de procesos electorales y de la autodeterminación de los pueblos, sin encontrar su inverso, su antítesis. Lo que sí es claro es que las intervenciones del hegemón se fundan con la revolución, sea ésta, guerrillera, o, justificada a través de elecciones, en una suerte de moneda de dos caras: junto con la idea de imperio, los fantasmas del comunismo renacen y se mutan. 


\section{Capítulo 6.}

\section{Doctrinas Regionales}


Las relaciones internacionales han sido moldeadas por las doctrinas de Estado de los gobiernos estadounidenses. Estas doctrinas entran en una relación dicotómica con las ideas de revolución latinoamericanas, en una suerte de dependencia dialéctica y dinámica: por un lado, las ideas de revolución son el resultado de la insatisfacción con respecto al imperio y sus doctrinas de estado; por otro lado, la visión utópica de una sociedad igualitaria, sin clases sociales, se mezclaba con los parámetros culturales de América Latina. Todas las doctrinas de estado del hegemón fungen como parámetros ideológicos que resguardan los principios del mundo democrático, a saber: la libertad, la prosperidad económica y la seguridad regional. Sin embargo, dentro del discurso regional, se considera la protección de los principios del mundo libre como una gama retórica que proviene de la percepción del hegemón y no involucra, en ningún aspecto, la percepción de quienes viven en el patio trasero. El recurso discursivo añade culpa al hegemón cuando se propone que la defensa de la democracia es realmente el resguardo de su propia libertad económica, de su propia seguridad, construyendo un imperio alrededor de Latinoamérica. Desde el siglo XIX, los Estados Unidos han generado políticas de Estado que envuelven a América Latina como una responsabilidad moral. Los principios de las doctrinas de estado estadounidense empiezan a moldearse en el Destino Manifiesto y en la Doctrina Monroe.

El Destino Manifiesto fue pensado en el siglo XIX como el destino de los Estados Unidos en el mundo occidental, en una suerte de voluntad divina y mesianismo estatal que intentaba persuadir sobre la necesidad de hacer manifiesto el rol del nuevo imperio: el propósito de la expansión del imperio hace referencia directa a la promoción y defensa de la democracia, y al establecimiento de la moral y salvación para las naciones de occidente. La necesidad manifiesta del rol del nuevo imperio tiene relación directa con la expansión del imperio en la región americana, "y entonces, con un sentido divino fundado en el destino manifiesto, occidente ha entrado al resto del mundo y ha buscado universalizar la cultura. En 
verdad, esta expansión, este proceso de glorificación propia, ha sido perseguida principalmente a través de la conquista imperialista y la penetración económica"108.

El Destino Manifiesto resalta la virtud de la democracia estadounidense y sus instituciones, en un acto de auto-adoración, mientras su misión de expandir su virtud democrática en la región se estructura en un imperio de libertad democrática. Dentro de este contexto entendemos la guerra entre Estados Unidos y México, en un intento por expandir el imperio por todo el norte del continente: después de que en 1836 Texas declarara su independencia de México, en 1848 Estados Unidos compró, a razón de la fuerza, 2 millones de kilómetros cuadrados de territorio mexicano, por lo cual se pagó alrededor de 15 millones de dólares, dejando, además, latente la posibilidad de anexar todo el territorio mexicano. El anexo de todo el territorio mexicano fue rechazado por razones raciales, tal como lo explica el Senador John C. Calhoun: "nunca hemos soñado en incorporar a nuestra Unión otro tipo de raza que no sea la caucásica, la raza blanca libre. Incorporar México sería la primera instancia para incorporar una raza india, porque la mayoría de los mexicanos son indios... ¡Protesto en contra de tal unión! Nuestro, señor, es el gobierno de la raza blanca" ${ }^{\prime 109}$.

La Doctrina Monroe, como brazo adyacente del Destino Manifiesto, fue pensada y estructurada por John Quincy Adams, Secretario de Estado durante la presidencia de James Monroe. La Doctrina Monroe elabora una hoja de ruta para los Estados Unidos con respecto a América Latina: "América para los americanos", es decir, el continente americano se convierte, después de la colonia española, y por obra y gracia del espíritu imperial del hegemón, en un protectorado regional que adquiere un nuevo nombre, The Backyard

108 LAWRENCE, Davidson, 2005, Christian Zionism as a Representation of American Manifest Destiny. Critique: Critical Middle Eastern Studies. 2005. Vol. 14, no. 2, p. 157. Traducción hecha por el autor.

109 CALHOUN, John C., 1848, Conquest of Mexico I Teaching American History. Teachingamericanhistory.org [online]. Disponible en: http://teachingamericanhistory. org/library/document/ conquest-of-mexico/ 
(El Patio Trasero), y el cual involucra un sentido de pertenencia al nuevo imperio. La Doctrina Monroe se esboza y delinea en tres principios fundamentales: primero, las colonias europeas quedan fuera de Latinoamérica; segundo, los Estados Unidos se abstienen de involucrarse en los asuntos políticos de Europa; y, se condena (en una suerte de prohibición más que una condena) la intervención de Europa en los nuevos gobiernos de Latinoamérica.

El Destino Manifiesto y la Doctrina Monroe influenciaron el interés de los Estados Unidos por Cuba, en un intento por replicar las experiencias en las adquisiciones de Texas, Oregón, California y parte de México. Bajo el Destino Manifiesto y la Doctrina Monroe, los intereses del hegemón se hicieron evidentes ante el temor de que Cuba caiga bajo el control británico. Para John Quincy Adams, Cuba era "una manzana que tenía que caer por gravedad a las manos de los Estados Unidos", mientras Thomas Jefferson confesó que Cuba era "la más interesante adhesión que pudo haberse hecho a nuestro sistema estatal"110. Dentro de este contexto, en 1848, el presidente Polk ofreció a España 100 millones por Cuba, sin ofrecer ayuda alguna a los intentos de independencia que surgían desde el interior de la isla. Sin embargo, los intereses de los Estados Unidos y de Cuba coincidieron cuando el acorazado Maine explotó en las costas cubanas, y la Guerra Hispano- Estadounidense estallara en una forma inusual, terminando con el control español sobre Cuba, y empezando con el protectorado estadounidense, mientras las Filipinas, Guam y Puerto Rico pasaron a propiedad del hegemón, "por quince años los Estados Unidos ejecutaron completo control económico y político sobre las islas mediante una serie de regímenes títeres y corruptos" 111 .

El Destino Manifiesto y la Doctrina Monroe se convierten simultáneamente en causales coyunturales a la revolución: las ideas de revolución reviven con fuerza en la región Latinoamericana como consecuencia de las doctrinas estatales del nuevo imperio,

110 BOURNE, Peter G., 1997, Denial of food and medicine. Washington, DC: American Association for World Health, p. 213.

111 Ídem 
y se multiplican en tanto y cuanto el nuevo imperio continúa con una intromisión brutal, cuasi enfermiza, y cruel en su Backyard. Latinoamérica se vio, de repente, ser parte de un protectorado que nunca pidió, del cual nunca fue consultada, y el cual involucraba intromisiones en las decisiones de los nuevos gobiernos latinoamericanos. Este protectorado aseguraba la sumisión de los nuevos gobiernos a través de la promoción de reformas constitucionales que estructuren la legalidad de su intervención. Así, Cuba incorpora a su constitución la Enmienda Platt, mediante la cual acepta el "derecho" de intervención de los Estados Unidos para resguardar la libertad democrática y la independencia del nuevo gobierno, mientras, por otro lado, se legalizaba el alquiler de Guantánamo por un plazo indefinido, en una suerte de concesión permanente, o posesión arbitraria. Esta arbitrariedad fue patente en la isla en 1906, 1912 y 1917, años en los cuales los Estados Unidos intervinieron militarmente en Cuba.

A principios del siglo XX, nos encontramos con el Corolario de Roosevelt, considerado como una enmienda a la Doctrina Monroe: los Estados Unidos se adjudicaban el derecho a intervenir en situaciones donde sus negocios fuesen afectados a causa de la inestabilidad interna, de manera que todo ataque "incivilizado" a los negocios estadounidenses serían moldeados con una intervención directa o indirecta por parte del gobierno norteamericano. La obediencia de los países latinoamericanos sería premiada con la cordialidad diplomática, mientras que la desobediencia sería castigada severamente. El Corolario a la Doctrina Monroe es un intento por controlar la región en un paradigma viejo que se ha denominado "civilización", y en conjunción con un paradigma nuevo denominado "democratización de los pueblos", estos, en conjunto, son muy parecidos, en esencia, a las ideas de una civilización impositiva manejada y pensada durante los tiempos de la colonia española. De esta manera,

si una nación muestra que sabe actuar con razonable eficiencia y decencia en temas sociales y politicos, si mantiene el orden y paga sus 
obligaciones, no necesita temer de interferencia alguna por parte de los Estados Unidos... si cada país bañado por el Mar Caribe mostraría progreso en una civilización estable y justa la cual con la ayuda de la enmienda Platt Cuba ha mostrado desde que nuestras tropas abandonaron la isla, y del cual muchas repúblicas en las Americas están mostrando contante y brillantemente ${ }^{112}$-Theodore Roosevelt, mensaje anual al Congreso.

Poco tiempo después, nos encontramos con la "diplomacia del dólar", término que fue utilizado por primera vez por el presidente Howard Taft en 1913. La "diplomacia del dólar" se configuró y estructuró alrededor de la idea de crear estabilidad a través de la promoción de espacios comerciales, de manera que los intereses comerciales del hegemón sean reflejados en los objetivos de la diplomacia norteamericana. Las relaciones internacionales debían mejorar las oportunidades financieras del hegemón. Aunque la "diplomacia del dólar" fue promocionada como una estrategia que substituyera las balas por los dólares, esta estrategia complementaba al Destino Manifiesto y la Doctrina Monroe de manera que la expansión del dominio imperial no se consolide únicamente gracias a la influencia e intromisión política, sino, también, a través de intercambio comercial.

$\mathrm{Al}$ parecer, nuevamente, Cuba se muestra como la receptora principal de la "diplomacia del dólar" Cuba era manejada por un gobierno militar asignado por los Estados Unidos, quienes aceleraron un proceso de inversión extranjera que los ayudará a recuperarse de las debacles económicas surgidas a partir de la guerra de independencia. Así, la industria de azúcar llegó a ser el primer producto de producción, con tal dependencia, que la economía crecía en tanto y cuanto lo hacía este sector industrial. El despunte de las exportaciones de azúcar fue posible a través del Tratado de Reciprocidad firmado en 1903, el cual garantizaba

112 ROOSEVELT, Theodore, 1905, Corollary to the Monroe Doctrine, 1904. Annual Message to the United States Congress. 
una porción del mercado estadounidense, empero, de todos los ingenios que operaban en Cuba en 1924, alrededor del $45 \%$ eran propiedad de compañías estadounidenses, mientras que el 57\% eran propiedad de europeos, cubanos y otros. La producción de los ingenios estadounidenses llegó a compartir el 64\% del mercado total de azúcar ${ }^{113}$.

Sin embargo, la Gran Depresión acabaría con la burbuja de prosperidad democrática formada sobre la isla, produciendo, de forma aledaña, que en Cuba empiece, nuevamente, a brotar sentimientos de revolución e independencia, esta vez no de la colonia, sino del protectorado estadounidense, de manera que la revolución encontró, nuevamente, su razón existencial y, así, prontamente, se encontró con el culpable de la crisis: el imperio norteamericano. La oposición al protectorado creció y se hizo fuerte mientras se organizaban grupos rebeldes. Así, entre el caos y la intervención, Ramón Grau Martín fue escogido como presidente, y fue quien embanderó las ideas revolucionarias que habían sido esparcidos por la isla rápidamente. En septiembre de 1933 declaró unilateralmente la abolición de la Enmienda Platt y, mientras expropiaba algunos ingenios extranjeros, ordenaba que al menos la mitad de los empleados trabajando en el sector industrial y en el comercio debieran ser cubanos. Poco después, Fulgencio Batista y el embajador de los Estados Unidos, Zaldívar, tramaban reemplazar a Grau San Martín. En enero de 1934, sin reconocer el gobierno de Grau, se permitió que Batista obligara la resignación del presidente Grau mientras se forjaban nuevas elecciones presidenciales. Y, bajo la doctrina de protección de los intereses estadounidenses, en 1940, Batista se instala como dictador, con el reconocimiento diplomático del imperio.

En 1969, se presentó la Doctrina Nixon, como un esfuerzo que intentaba mostrar al mundo la decisión de evitar la intervención directa en los asuntos internos de los países de la región, mientras se esperaba que estos cuidaren de sí mismos. Nixon anunció al mundo que,

113 DE LA FUENTE, Alejandro, 2001, A Nation for All: Race, Inequality, and Politics in Twentieth Century Cuba. Chapel Hill, N.C.: University of North Carolina Press, p. 105. 
- Primero, los Estados Unidos mantendrán sus compromisos acordados.

- Segundo, proveeremos de un escudo si una potencia nuclear amenaza la libertad de una nación aliada o de una nación cuya supervivencia consideramos vital para nuestra seguridad.

- Tercero, en casos que involucren otro tipo de agresiones, debemos proveer de asistencia militar y económica cuando sea solicitada en concordancia con nuestros compromisos pactados ${ }^{114}$.

En referencia a los documentos desclasificados en las últimas décadas, sabemos la intervención del gobierno de Nixon en el derrocamiento y muerte de Salvador Allende, correspondiendo a los referentes doctrinales pasados, como a su propia doctrina. Así, de acuerdo a Edward Korry, embajador de Estados Unidos en Chile desde 1967 a 1971, Nixon había preparado el derrocamiento de allende a través del apoyo a grupos militares en subversión, de manera que los Estados Unidos repitiesen el capítulo escrito en República Dominicana pocos años antes, cuando se derrocó al presidente Juan Bosch en 1965. Korry cuenta que Nixon "me saludó cálidamente y le dijo a Henry [Kissinger], el embajador nos cuenta siempre todo, tal y como es, y empezó a soltar un discurso de cinco o seis minutos sobre cómo iba a aplastar a Allende. No paraba de golpear su puño contra la mano, y que lo destruiría y que lo hundiría económicamente, que iba a exprimirlo económicamente"115.

Sin embargo, Nixon no fue necesariamente el que pensó en la planificación de las dictaduras más crueles y sangrientas en el continente, sino, el intelectual que manejaba las relaciones internacionales de los Estados Unidos, Henry Kissinger. Kissinger fue el cerebro organizador de la Operación Cóndor, mediante la cual

114 NIXON, Richard, 1969, Nixon Doctrine. Washington: U.S. Government.

115 KORRY, Edward, 2007, Lo que dijo Nixon sobre Allende. Disponible en: https: / / www. youtube.com $/$ watch? $\mathrm{v}=\mathrm{hQvAVXKNrPA}$ 
se estructuró un esfuerzo de inteligencia y seguridad para combatir el terrorismo y la subversión comunista que se multiplicaba con rapidez en el continente americano. La políticas de Nixon crearon un nuevo precedente en la región, empero, también, crearon nuevos resentimientos en los movimientos revolucionarios que, para la época, se habían multiplicado y fortalecido rápidamente, de manera que la Guerra Fría se reconstruían en Latinoamérica de una forma sui géneris, con los movimientos revolucionarios, por un lado, y con la intromisión del imperio, por el otro, sabiendo que la revolución no peleaba en igualdad de condiciones, aunque pretenda convulsionar la historia en un nuevo dinamismo, sino, más bien, dentro de burbujas románticas y utópicas que dibujaren un camino con un rumbo arbitrario.

Después de la experiencia Nixon, durante la década de los 80, aparece la Doctrina Reagan como una estrategia de política internacional que intentó exterminar la influencia de la Unión Soviética y, por ende, del comunismo, en la región latinoamericana. Para detener la influencia de la Unión Soviética se estructuró sistemas de intervención que involucraron el financiamiento de contra guerrillas que hicieran contra peso a las formadas por los movimientos revolucionarios de Latinoamérica. Así, durante el gobierno de Reagan, las políticas internacionales de presión utilizadas para derrotar a la Unión Soviética se pretendieron emular en Centro América de manera que el comunismo fuere destruido. La Doctrina Reagan se enlista dentro de las doctrinas estadounidenses que practican la Realpolitik: en referencia a las relaciones internacionales, la ideología queda relegada al discurso, mientras se prioriza la obtención de resultados a través de métodos que logren la exterminación de los obstáculos encontrados en el camino.

Nicaragua ejemplifica la Doctrina Reagan de una forma clara y, de momentos, estremecedora: la dictadura de los Somoza protagonizó uno de los episodios más vívidos y crueles de la historia dinámica entre la revolución y el imperialismo, dentro una 
guerra civil que fue patrocinada por el gobierno estadounidense. Los Somoza fueron aliados cercanos a los Estados Unidos y, como respuesta a esta dictadura, aparece una obviedad dentro de la dinámica de la historia latinoamericana, la organización de movimientos revolucionarios en forma de grupos guerrilleros, quienes buscaban lo que todo grupo guerrillero, la obtención del poder con la ayuda del exterminio del enemigo común llamado imperialismo. Este grupo toma el nombre de un emblema en la lucha de la revolución, Augusto Sandino: la guerrilla de los Sandinistas fue conformado por campesinos y trabajadores quienes, en un triunfo de la revolución, tomaron el poder en 1979 después de derrocar a los Somoza. Reagan, inmediatamente después de su elección, relacionó el movimiento sandinista con la influencia soviética y el comunismo: Reagan encontró la justificación para sus nuevas políticas en la región. Así, a través de la CIA, se organizó y financió grupos paramilitares que derrotasen a los sandinistas. Estos grupos paramilitares se asentaron en Honduras y Costa Rica y tomaron el nombre de "La Contra", aunque Reagan se empeñó en llamarlos los "freedom fighters" (luchadores de la libertad). Los contras combatieron al Ejército Popular Sandinista financiado, presumiblemente, por la Unión Soviética y, prontamente, derrotaron a los Sandinistas quienes tuvieron que ceder el poder a un gobierno que surgiera de un sistema democrático de elecciones.

A principios del siglo XXI, Latinoamérica se quebranta en dos polos, en una suerte de mutación de la Guerra Fría: aparecen los movimientos del socialismo del siglo XXI, por un lado, y, por otro, la representación del conservadurismo y liberalismo norteamericano. En esta nueva dinámica se ejercen políticas con nuevos conceptos, y prácticas con nuevas justificaciones: la extraterritorialidad, concepto acuñado extensamente por George W. Bush, y practicado por Álvaro Uribeenla región andina, seextiende conceptualmentecomo prácticas y leyes que "permiten a los países convertir en delito actos cometidos fuera de sus fronteras y tratarlos tal como si se hubieran cometido dentro de ellas"116. Esta doctrina fue consumada con justificaciones

116 CATHERINE, Beaulieu, 2008, Leyes extraterritoriales por qué no funcionan y cómo pueden fortalecerse. Bangkok: ECPAT international. 
que delineaban la eliminación de grupos guerrilleros en territorio ecuatoriano. En marzo de 2008, el campamento de Angostura fue bombardeado por aeronaves colombianas con la seguridad de que las Fuerzas Revolucionarias de Colombia, F.A.R.C., hospedaban en tal campamento a uno de sus líderes emblemáticos, Raúl Reyes. El ataque se realizó con extrema precisión, dejando únicamente tres personas vivas, la mexicana Lucía Morett, y las colombianas Doris Bohórquez y Martha Pérez, quienes fueron rápidamente acogidas y protegidas por el gobierno nicaragüense de Daniel Ortega, quien aplaudió la lucha revolucionario dirigida por las F.A.R.C.

El principio de extraterritorialidad ha marcado un nuevo capítulo en las doctrinas estadounidenses, no solo porque no es el hegemón quienla ejerce de manera directa, sino quela extrapola a otras democracias quienes, con tal direccionamiento, han pretendido justificar sus actos de intromisión en otras naciones. No obstante, la criminalidad, en manos de la revolución, queda relegada a una mera descripción realizada entre líneas, porque la revolución se ha permitido a sí misma utilizar cualquier medio en su lucha contra la tiranía del opresor, llámese esta burguesía o imperialismo. Sin lugar a duda, las doctrinas del hegemón han empujado a la revolución al extremo de justificar su lucha armada, empero, de la misma manera en que este juego dialéctico se retroalimenta, se justifica la existencia de nuevas doctrinas, extremas o agresivas, porque la revolución se ha diseñado como un acto de rebeldía armada. De esta manera, la dinámica de la historia de Latinoamérica queda relegada a un juego de opuestos, quienes reaccionan en relación directa, con intensidades similares y justificaciones análogas, y quienes llegan a justificarse mutuamente: la revolución existe en tanto y cuanto existe el imperialismo.

Por otro lado, en América Latina surgieron varias doctrinas de los derechos humanos y las relaciones internacionales, entre las más importantes nos encontramos con la doctrina Betancurt y la doctrina Roldós. Rómulo Betancourt Bello fue presidente de Venezuela en 
dos ocasiones, 1945-1948, 1959-1964. Durante su segundo mandato estuvo repleto de cambios estructurales como la reforma agraria, la creación de una nueva constitución y el alejamiento diplomático de las dictaduras del continente. La doctrina Betancourt nace el 13 de febrero de 1959, durante la posesión a la presidencia, en un elocuente y potente discurso,

Solicitaremos cooperación de otros gobiernos democráticos de América para pedir, unidos, que la OEA excluya de su seno a los gobiernos dictatoriales porque no solo afrentan la dignidad de América, sino también porque el Artículo 1 de la Carta de Bogotá, Acta constitutiva de la OEA establece que solo pueden formar parte de este organismo los gobiernos de origen respetable nacidos de la expresión popular, a través de la única fuente legítima de poder que son las elecciones libremente realizadas. Regimenes que no respeten los derechos humanos, que conculquen las libertades de sus ciudadanos y los tiranice con respaldo de las politicas totalitarias, deben ser sometidos a riguroso cordón sanitario y erradicados mediante la acción pacífica colectiva de la comunidad jurídica internacional ${ }^{117}$.

La doctrina Betancourt promueve dos principios inviolables en las relaciones internacional, y por medio de los cuales, los regímenes políticos deben ser aprobados y apoyados, o condenados y erradicados por la comunidad internacional. La doctrina se construye, entonces, a través de la observación de un origen político respetable, nacido en la elocuencia de las elecciones libres, siendo estas la expresión popular más clara de toda nación-estado. Además, Betancourt sugiere que la salud de los regímenes políticos de América Latina se valore en su respeto, protección y promoción de los derechos humanos, abriendo la puerta a la formalidad

117 LA DOCTRINA BETANCOURT: ANÁLISIS Y TEXTOS FUNDAMENTALES, 2016. Democracia Participativa [online]. Disponible en: https: / / democraciaparticipativa.net/ documentos-data-a-referenda/documentos-en-espanol / instrumentos-internacionalesy-declaraciones / 9548-la-doctrina-betancourt-analisis-y-textos-fundamentales.html 
diplomática para erradicar los regímenes que atenten contra este principio. Las formas de erradicación deben ser pacíficas, colectivas y jurídicas. Quizá, ésta sea la principal limitante de la doctrina Betancourt porque estas formalidades buscan la justificación a un acto de rechazo diplomático, no obstante, no busca la practicidad en la erradicación de las dictaduras: la limitante de la diplomacia abre el abanico a la prolongación de los autoritarismos.

Betancourthabía condenado crudamentela dictadura de Rafael Leónidas Trujillo en República Dominicana, la cual fue categorizada como la más cruenta y sangrienta de América. Betancourt había recibido varios atentados contra su vida, el primero intento ocurrió en la Habana, Cuba, en 1950, cuando un sicario falla asesinarlo con una jeringa. El expresidente logró esquivar al atacante con un manotazo, y luego recuperó la jeringa, la cual contenía veneno extraído de una cobra ${ }^{118}$. Años más tarde, en 1953, Betancourt, quien residía en Costa Rica, recibió la alerta de la embajada venezolana de la llegada de dos sicarios cubanos a San José. Con el ayuda de personal de inteligencia y hombres entrenados en el uso de armas, los sicarios fueron encontrados y asesinados. Finalmente, el 24 de junio de 1960, Rómulo Betancourt sobrevivió a un atentado con explosivos,

No me cabe la menor duda de que en el atentado (...) tiene metida su mano ensangrentada la dictadura dominicana. Hay una conjunción de esfuerzos entre los desplazados el 23 de enero y esa satrapía para impedir que Venezuela marche hacia el logro de su destino final. Pero esa dictadura vive su hora preagónica. Son los postreros coletazos de un animal prehistórico incompatible con el siglo veinte $e^{119}$.

En el caso de Jaime Roldós Aguilera, aunque su período como presidente ecuatoriano fue muy corto (1979-1981), su impacto

118 MONDOLFI, EDGARDO, 2016, El día del atentado. El frustrado magnicidio contra Rómulo Betancourt. Editorial Alfa.

119 Ídem, p. 56. 
en las doctrinas de relaciones internacionales se mantiene en el tiempo. Roldós fallece en un supuesto accidente aéreo en el cerro de Huayrapungo, en la provincia de Loja, el 24 de mayo de 1981. La década de los 70, se vio plagada por varias dictaduras militares que representaban la represión a todo movimiento comunista: la Guerra Fría generó las dictaduras más cruentas de la región, con ideologías que danzaban entre los grises de las izquierdas y derechas ${ }^{120}$. Así, el contexto de la doctrina Roldós se construye alrededor de la imagen construida con las dictaduras de Augusto Pinochet en Chile, Fidel Castro en Cuba, el Proceso de Reorganización Nacional en Argentina, Alfredo Stroessner en Paraguay, Hugo Banzer Suárez en Bolivia, Anastasio Somoza Debayle en Nicaragua, François Duvalier en Haití, Juan María Bordaberry en Uruguay, y Guillermo Rodríguez Lara en Ecuador.

Bajo la sombra del Sesquicentenario aniversario de la Primera Constitución del Ecuador, acaecido en la ciudad de Riobamba, la Carta de Conducta emerge, frente a las naciones del Grupo Andino, el 15 de marzo de $1980^{121}$. El Grupo Andino estaba conformado por Ecuador, Colombia, Perú, Bolivia y Venezuela. La Carta de Conducta representa la voz de los derechos humanos como el escudo de armas de la diplomacia. La doctrina Roldós propone tres ejes fundamentales para la conservación de la armonía entre los países de América Latina. Primero, la construcción de un ordenamiento jurídico común que se centre en los fundamentos de la democracia, popular y con carácter participativo, tomando en cuenta la autodeterminación de los pueblos, la no intervención y el pluralismo ideológico. Segundo, impulsar el desarrollo integral inspirado en la justicia social, y a través de políticas comunes. Tercero, y quizá el principio más importante, el respeto a los derechos humanos, políticos, económicos y sociales: los estados están obligados a la defensa de los derechos

120 VALENCIA GRAJALES, José y MARÍN GALEANO, Mayda, 2016, Elementos que describen una dictadura en América Latina. Investigación. 2016. Vol. 8, no. 1, p. 43-56.

121 ROLDÓS BUCARAM, Martha, 2012, Actualidad y Vigencia de La Carta de Conducta. Guayaquil: Universidad de Guayaquil. 
humanos, y la acción conjunta en protección de estos derechos no viola el principio de intervención, y es una obligación de los estados del Grupo Andino ${ }^{122}$.

La intención de la Carta de Conducta se fundamenta en una democracia que se asiente encima de los derechos humanos, su defensa "es una obligación internacional a la que están sujetos los Estados y que, por tanto, la acción conjunta ejercida en protección de esos derechos no viola el principio de no intervención"123. De esta forma, se justifica la intervención en un estado de Grupo Andino en los casos en los cuales los derechos humanos, emergidos por medio de un sistema democrático, sean vulnerados sistemáticamente: la obligación de la protección de los derechos humanos se establece como la piedra angular de la Doctrina Roldós. Así, se intenta aprobar la defensa de los derechos humanos como un sistema de jurisdicción supranacional. Así, la idea de principios universales se impone sobre la idea de la subjetividad de las construcciones culturales: la relatividad que relegada a un absurdo en tanto y cuanto se considere como verdadera la promoción de principios universales, los cuales deben ser defendidos y promovidos.

El 24 de mayo de 1981, Jaime Roldós Aguilera muere, con el resto de la tripulación, en un avión pilotado por la Fuerza Aérea Ecuatoriana. La versión oficial se impune a través la teoría de un accidente de aviación: La Junta Investigadora de Accidentes concluyó que la responsabilidad recaía en un error del piloto. Después, las investigaciones realizadas por el Congreso Nacional en 1982 concluyeron que el avión se estrelló contra la montaña debido a fallas mecánicas ${ }^{124}$. En ambos casos, la muerte de Roldós había sido considerada por el gobierno como un hecho fortuito. El documental

122 ASOCIACIÓN DE FUNCIONARIOS Y EMPLEADOS DEL SERVICIO EXTERIOR ECUATORIANO, 2013, Carta de Conducta de Riobamba [online]. Disponible en: https:/ / afese.com/img/revistas/revista44/riobamba.pdf

123 Ídem, p. 230.

124 VÁSQUEZ, Jorge Daniel, 2018, Sobre la cuestión de la memoria en Ecuador. La muerte de Jaime Roldós ante la prevención historiográfica. Fuerza de Campo. 2018. Vol. 2, no. 1, p. 88-103. 
"La muerte de Jaime Roldós"125, nace el 2013, muestra una versión posible de los hechos: las políticas de la supremacía de los derechos humanos sobre el ordenamiento jurídico nacional no fueron del agrado de las dictaduras del continente, "el comandante general del Ejército en el gobierno de Roldós, Richelieu Levoyer, que además traza la hipótesis de que en la muerte del entonces mandatario tuvo un rol central la dictadura argentina 1976-83" ${ }^{126}$. Esta versión supone la existencia de un Plan Viola, acuñado por el nombre del dictador Roberto Viola, para detener el avance de las tendencias comunistas en América Latina. Este plan habría sido parte de la Operación Cóndor, la cual fue coordinada por las dictaduras de Brasil, Argentina, Chile, Bolivia, Paraguay y Uruguay para neutralizar la influencia del comunismo. Así, pareciera inequívoco pensar en la relación que surge de la muerte del presidente ecuatoriano con las muertes del presidente panameño Omar Torrijos en 1981, del Comandante General del Ejército peruano, Omar Hoyos, en el mismo año.

125 SARMIENTO, Manolo and RIVERA, Lisandra, 2013, La muerte de Jaime Roldós. [film]. Quito: La Maquinita, 2013.

126 TÉLAM S.E. AGENCIA NACIONAL DE NOTICIAS, 2013, Un documental indaga en la muerte del ex presidente Roldós y la vincula con la dictadura en la Argentina. [online]. 2013. Internacional. Disponible en: http://www.telam.com.ar/notas/201308/30023un-documental-indaga-en-la-muerte-del-ex-presidente-roldos-y-la-vincula-con-ladictadura-en-la-argentina.html 


\section{Conclusiones}

Pensar en la idea de revolución se convierte en la principal tarea de este artículo, no porque se pretenda redefinir el concepto de revolución, esto ha sido ampliamente debatido, sino porque se intenta entender la idea de revolución dentro de una estructura discursiva utilizada en América Latina durante el siglo XX. La estructura de pensamiento discursivo se formaliza en la utilización de una triada de ideas: mesías, pueblo, demonio. Esta triada, que sirve de fundamento discursivo que se embellece con cierta conceptualización marxista de la realidad.

Este artículo intenta entender al revolucionario como el mesías, escogido por el destino, por la historia, o por la divinidad, con un halo de mesianismo, convertido en el único salvador, el único con la sabiduría necesaria para entender el camino del pueblo hacia la libertad, hacia la felicidad, hacia el fin de la historia. Pero la idea de mesías no puede existir sin la idea del demonio, encarnizada en la burguesía, en el imperio, en la prensa, o en la empresa privada, un demonio que se ha enriquecido mientras ha empobrecido al pueblo, un opresor que ha beneficiado a pocos mientras ha explotado al proletariado. Por último, la idea de mesías y de demonio no tienen sentido sin la existencia de un agente que reciba su influencia, el pueblo. La idea de pueblo se configura en aquellos millones que se ha visto oprimidos, que viven en pobreza, en miseria, un pueblo que se ha visto en la necesidad de la intervención de un salvador, el mesías político, el revolucionario.

La estructura discursiva del mesías, villano y pueblo, se ha utilizado durante el siglo XX para justificar los movimientos revolucionarios: la idea de un opresor justifica la existencia de un revolucionario, el único que puede salvar al pueblo de un destino cruel. La triada se comporta de forma unívoca y dinámica: la idea de mesías evoca la idea de pueblo y demonio, de igual forma, la idea de pueblo evoca la idea de mesías y demonio. Esta estructura discursiva ha tomado prestado el lenguaje marxista para ubicarlo 
dentro de una temporalidad de rebeldía regional. El escrito propone que, tomando en cuenta el contexto el lenguaje marxista, el revolucionario existe en tanto y cuanto la burguesía exista, y en tanto y cuanto el proletariado es oprimido. Esto es evidente cuando se hace uso de la triada del mesías, el pueblo y el demonio. El mesías será el revolucionario, el pueblo el proletariado, y el demonio la burguesía.

Latinoamérica ha escrito su historia contemporánea dentro de las singularidades que han surgido de procesos y discursos revolucionarios, todos ellos enmarcados en momentos históricos mundiales como en rasgos endógenos. Las ideas contemporáneas de revolución en América Latina se han dibujado a través de sentimientos en contra de imposiciones, intervenciones o doctrinas regionales decididas y debatidas en territorios extraños a la región. Las ideas de revolución se fortalecieron cuando encontraron intuitivamente la triada retórica adecuada: por un lado, el discurso que concibe un pueblo en miseria, pobreza, o desempleo; por otro, la necesidad de sacrificar a los que son y a los que parecen culpables de la instauración de esta situación; y, por último, el revolucionario, que puede convertir en el mesías esperado, quien tomará la responsabilidad de desaparecer el mal, o puede convertirse en un falso profeta, un revolucionario de nombre pero con una vida larga como burgués.

En laúltima década se ha conceptualizadoel uso de la estrategia argumentativa que ha sido constante en las ideas contemporáneas de revolución en América Latina. Esta estrategia discursiva ha sido utilizada en los casos de estudio. En toda revolución, la estructura argumentativa se describe a continuación: en cada historia hay un héroe, un crimen, una víctima, y un villano. En la historia de defensa personal, el héroe y el villano son los mismos. El villano es inherentemente malo e irracional: el héroe no puede razonar con el villano; tiene que luchar y derrotarlo o matarlo. En ambos casos, la víctima debe ser inocente y que sobrepase cualquier reproche. Esta triada discursiva ha sido adaptada al lenguaje marxista, mostrando al 
héroe como el revolucionario, con cierto halo mesiánico, dispuesto a caminar por el sendero del determinismo histórico del materialismo; al villano como el burgués o representante del imperio; y a la víctima como al pueblo, la fuerza proletaria. La triada no intenta entender los procesos políticos y sociales de los casos estudiados, sino entender la idea discursiva que los denota.

La idea de revolución hace uso de herramientas retóricas en las cuales la víctima, el villano y el héroe son parte indispensable del discurso. Estas herramientas vienen por herencia de un espacio imaginario y discursivo que se lo debe entender dentro de la lucha de clases: una estructura de pensamiento aprendido de la tradición marxista, la lucha de clases requiere de una matriz teórica definida. Se propone una triada construida a partir de estructuras retóricas, se la ha contextualizado dentro del espacio discursivo de la lucha de clases: el héroe, es decir el revolucionario, representante del proletariado, guiará hacia la lucha en contra del villano, en contra de la burguesía, de la libre empresa, del imperio. Esta estructura de pensamiento ha servido como plataforma para construir pensamientos ideológicos que se acercan al marxismo y se alejan, inevitablemente, del liberalismo. A través de esta estructura conceptual intentamos entender los movimientos revolucionarios en América Latina.

Así, la estructura retórica de Lakoff tiene sentido en un contexto de rebelión que se acerca a una izquierda latinoamericana, influenciada por la estructura de pensamiento marxista. De hecho, el marxismo ha provisto de "un punto de vista filosófico a, por lo menos, una tercera parte de la población mundial en la segunda mitad del siglo XX". El modelo retórico se pinta de un discurso de izquierda adaptable, haciendo que el discurso revolucionario se entienda por intermedio de la existencia de la víctima, el mesías y el victimario. En la práctica, el modelo argumentativo se dibuja desde marxismo, aunque algunas prácticas políticas difieran del discurso. 
La imagen de villano emerge en el ideario de la revolución en una suerte de causante de la miseria en la que vive el pueblo, causante de la riqueza de unos pocos en detrimentos de las masas sociales. El villano emerge en el discurso revolucionario como el enviado del mal, representado en la burguesía o el imperio, un personaje político o militar que está dispuesto a favorecer a los representantes de un gobierno liberal, imperialista o burgués. La estructura discursiva de la revolución coloca a los villanos dentro de una esfera llamada capitalismo, individualismo, liberalismo.

La imagen de villano evoca inevitablemente al mesías. La existencia del villano es imposible sin la existencia del enviado divino, alguien que provenga del proletariado. Una persona con un rasgo de espiritualidad comunitaria, que ha dejado de lado la tradición católica y se ha involucrado en una suerte de espiritualidad endógena, creando una esfera inmaculada alrededor de todo lo que se llama ancestral, y alrededor de las cosmovisiones de los pueblos autóctonos. El revolucionario de América Latina ve con suspicacia las tradiciones culturales imperiales, porque el imperio es la fuente de la maldad, y lo divino es todo lo considerado como nativo, indígena, milenario, en sí, todo lo concebido como sabiduría ancestral.

El mesías de la revolución requiere de dos elementos imprescindibles. Primero, principios que resalten la idea del pueblo (proletariado) y la idea del villano, del enemigo común. Segundo, requiere de un tiempo corto de revolución, en la cual su imagen se vea ensalzada por su sacrificio, su perseverancia y su valentía, dispuesto a que lo maten, dispuesto a ofrendar su vida. Los revolucionarios se convierten en mesías al ver una muerte temprana, trágica, la muerte que acaece en el fragor de la lucha, en la cima de su liderazgo. Aquellos revolucionarios con largas vidas, desaparecen en el tiempo, su imagen deja de ser divina para convertirse en una imagen mundana.

La revolución ve a la víctima como una encarnación continua de un pueblo homogéneo, sin matices, que siempre ha sufrido, que 
siempre ha padecido. Un pueblo que ha sufrido los embates de las crisis causadas por la burguesía. La idea de pueblo no contempla diferencias o discrepancias, la colectividad de pensamiento sobrepasa la individualidad, todos sufren, todos lloran, todos están en la búsqueda de un mesías. La idea de pueblo no admite que dentro de él puedan existir capitalistas, burgueses, individualistas, amantes de las riquezas, etc. La homogeneidad es un factor común. La idea de pueblo tiene fuerza en sí misma, la concepción reanima la idea de proletariado, la idea de gentiles, la idea de clases sociales. La víctima toma fuerza en sujetos como el pueblo, y toma color en adjetivos que conllevan estigmas históricos como: la lucha campesina, los movimientos indígenas, las luchas ancestrales.

Esta conjunción de modos de argumentación llevó a los movimientos revolucionarios a justificar la violencia como una de las fuerzas de la historia. De hecho, por mucho tiempo, se ha pensado en revolución con una imagen estereotípica: un revolucionario vestido de civil, con un rifle que guinda del hombro, con una barba frondosa y con un cigarro entre comido que cuelga de las comisuras de la boca. Esta imagen iba de la mano con la idea de justicia: el justiciero era una persona de pueblo, con al ánimo inquebrantable y con un sistema moral de un solo principio, eliminar al villano. La necesidad de llegar a la confrontación de clases a recorrido dos caminos: primero, salvando las armas apuntadas directamente a los culpables; segundo, a través de procesos electorales. El primero fue una constante para la región latinoamericana en la mayor parte del siglo XX; el segundo, una alternativa elegida por pocos los movimientos socialistas, los cuales hacen uso de los instrumentos democráticos para luego menoscabarlos y manipularlos.

Al rescate de esta víctima llega con fuerza histórica el esperado mesías, aquel revolucionario que está dispuesto a sacrificar la vida por un ideal, el bienestar del pueblo, el bienestar del proletariado. Para ello, no es imprescindible utilizar los sistemas democráticos, porque bien se lo puede hacer a través de: el uso de las armas, la organización de guerrillas, y del derrocamiento de gobiernos. La 
idea de víctima tiene valor únicamente en un contexto en el cual el victimario, o villano, este plenamente identificado, y en el cual el salvador esté encarnado en una persona. 


\section{Referencias}

-. 10 encuentros de famosos con Chávez (+Fotos). Colarebo [en línea]. 3 de agosto de 2014. Disponible en: http: / / www.desdelaplaza. com/wp-content/ uploads / 2014/07 / Chávez-MarioBenedetti. jpg

-. Augusto C. Sandino, a la libertad siempre. Taringa [en línea]. Disponible en: http://www.taringa.net/posts/ info/ 11430674 / Augusto-C-Sandino-a-la-libertad-siempre. html

-. Enmienda Platt de 1901. Instituto de Investigaciones Jurídicas UNAM [en línea]. Disponible en: https:/ / archivos.juridicas. unam.mx/www/bjv/libros/6/2525/15.pdf

-. Tratado de paz entre España y los Estados Unidos de América firmado en París el 10 de diciembre de 1898. Instituto de Investigaciones Jurídicas UNAM [en línea]. Disponible en: $\quad$ https: / / archivos.juridicas.unam.mx/www / bjv / libros /6/2525/14.pdf

ALFONSO, Rodolfo. Autocrítica de Heberto Padilla. Cuba / Cultura / Revolución, 1971, no 20.

AMORÓS, Mario, 2000, La CIA contra Salvador Allende. Centro de Estudios Miguel Enríquez. Historia Político Social-Movimiento Popular [online]. Disponible en: https://www.archivochile. com/S_Allende_UP/otros_doc/SAotrosdoc0008.pdf

\section{ASOCIACIÓN DE FUNCIONARIOS Y EMPLEADOS DEL} SERVICIO EXTERIOR ECUATORIANO, 2013, Carta de Conducta de Riobamba [online]. Disponible en: https: / / afese. $\mathrm{com} / \mathrm{img} /$ revistas / revista44/ riobamba.pdf 
ASOCIACIÓN DE INVESTIGACIÓN Y ESTUDIOS SOCIALES. Compendio de historia de Guatemala, 1944-2000, 2004, Guatemala.

AZNARES, Juan Jesús, 2006, Allende: “Si quedo herido, pégame un tiro”. El País[online]. 2006. Disponible en: https: / / elpaís.com/ diario/2006/12/17/domingo/1166331155_850215.html

BANHEIRENSE. Hugo Chávez acusa EUA de entrarem no Haiti com "Licença para matar". Disponible en: https: / / youtu.be/ g1xWote0iJM

BELL, David, 1964, Memorandum for the President. Archivo impreso: Confidential file, box 25. Austin, Texas.

BENEDETTI, Mario. Che 1997. Disponible en: http: / / www.poemasdel-alma.com/mario-benedetti-che-1997.htm

BERRYMAN, Phillip. Teología de la liberación. Los hechos esenciales en torno al movimiento revolucionario en América Latina y otros lugares, 1989, p. 11.

BIARDEAU, Javier, 2009, El eje Palanquero-Apiay-Marandúa: la trama oculta de las bases militares imperiales contra Venezuela I LaClase.info. Laclase.info. Disponible en: http://laclase. info/content/el-eje-palanquero-apiay-marandua-la-tramaoculta-de-las-bases-militares-imperiales-c/

BLANES, Jaume Peris. " Libro de Manuel" de Julio Cortázar, entre la revolución política y la vanguardia estética. Cuadernos de investigación filológica, 2005, no 31, p. 146.

BOLAÑOS, Alejandro. Sandino. Masaya, Nicaragua. Fundación Enrique Bolaños, 2002. ISBN: 1-877926-54-X. 
BOURNE, Peter G., 1997, Denial of food and medicine. Washington, DC: American Association for World Health, p. 213.

BRIGAGÃO, Clóvis, 2011, Latin America: A Panorama of Security and Integration. En: Current Challenges for Disarmament and Peace Operations on the Political Agenda[online]. Rio de Janeiro. 2011. Disponible en: https://www.kas.de/c/ document_library / get_file?uuid=c85cb7de-b84d-c36e-19a35b63666ceba5\&groupId $=252038$

CALHOUN, John C., 1848, Conquest of Mexico I Teaching American History. Teachingamericanhistory.org [online]. Disponible en: http: / / teachingamericanhistory.org/library/document/ conquest-of-mexico /

CARBONE, Valeria Lourdes, 2014, Cuando la Guerra Fría llegó a América Latina... La Política Exterior Norteamericana hacia Latinoamérica durante las presidencias de Eisenhower y Kennedy (1953-1963). Centro Argentino de Estudios Internacionales. Programa Historia de las Relaciones Internacionales [online]. Disponible en: https://www. academia.edu/2567374/_Cuando_la_Guerra_Fr\%C3\%ADa_ llegó_a_América_Latina..._La_Pol\%C3\%ADtica_Exterior_ Norteamericana_hacia_Latinoamérica_durante_las_ presidencias_de_Eisenhower_y_Kennedy_1953-1963_

CARO, Jorge Enrique y GONZÁLES, Roberto. Repercusiones de la Revolución Cubana en Colombia. En: RODAS, Germán. Cuba y Latinoamérica en los años 60. Quito: Ediciones La Tierra, 2009.

CASA TIEMPO, 2018, Ecuador le pidió a Estados Unidos desalojar la base militar de Manta. El Tiempo. 2018. Disponible en: https: / / www.eltiempo.com/archivo/documento/CMS-4417675 
CASTRO, Fidel, 1982, Fidel Castro on Chile. New York: Pathfinder Press.

CATHERINE, Beaulieu, 2008, Leyes extraterritoriales por qué no funcionan y cómo pueden fortalecerse. Bangkok: ECPAT international.

CHÁVEZ, Hugo. ¡No cambiemos el clima, ¡cambiemos el sistema! Rebelión [en línea]. 16 de diciembre de 2009. Disponible en: http: / / www.rebelion.org/ noticia.php?id=97198

CHÁVEZ, Hugo. Nada podrá detener la revolución en América Latina. The Omar Herald [en línea]. 26 de septiembre de 2009. Disponibleen:http: / / omar-herald.blogspot.com/2009_09_01_ archive.html

CHEN, Yongfa, 2001, Seventy years of the communist Chinese Revolution. Taibei: Lianjing Publisher.

CHENG, Yinghong y MANNING, Patrick, 2003, Revolution in Education: China and Cuba in Global Context, 195776. Journal of World History [online]. 2003. Vol. 14, no. 3. Disponible en: http://www.manning.pitt.edu/pdf/2003. RevolutionInEducation.pdf

COMMITTEE ON FOREIGN RELATIONS, U.S. Senate, Mutual Security Act of 1955, 84th Cong. 1st Sess., Archivo impreso.

CONSTITUCIÓN DE LA REPÚBLICA DE ECUADOR. Preámbulo, 2008.

CORTÁZAR, Julio. El escritor y el lector bajo las dictaduras en América Latina. El País, 25 de junio de 1978. 
CORTÁZAR, Julio. Julio Cortázar ante la Orden de la Independencia Cultural "Rubén Darío". Ventana, 12 de febrero de 1983.

CRISORIO, Carolina. La Argentina en la Segunda Posguerra y la Revolución Cubana. La década de 1960. En: RODAS, Germán. Cuba y Latinoamérica en los años 60. Quito: Ediciones La Tierra, 2009.

CUIJIN, Mario Benedetti y Hugo Chávez en Montevideo. Disponible en: https: / / www.youtube.com/watch?v=S10zGIrley4

DE LA FUENTE, Alejandro, 2001, A Nation for All: Race, Inequality, and Politics in Twentieth Century Cuba. Chapel Hill, N.C.: University of North Carolina Press, p. 105.

DEL PINO, Andrea Rosa, 2016, Los 900 millones de herencia que, según Forbes, deja Fidel Castro. El Mundo [online]. 2016. Disponible en: https://www.elmundo.es/ loc/2016/12/02/58404ca122601dbb038b45c6.html

DIARIO EL UNIVERSO, 2019, Carter implica a EE.UU. en golpe a Venezuela y critica a Chávez. Guayaquil, 21 de septiembre.

DULLES, John News Conference. Washington. Department of State: American Foreign Policy 1950-1955, 8th june1954,

EISENHOWER, Milton, 1959, Report to the President: United StatesLatin American Relations. Archivo impreso: Department of State Bulletin.

EL COMERCIO, 2010, Hugo Chávez cumplió 11 años en el poder y se quiere quedar otros 11 más. [online]. 2010. Mundo. Disponible en: http:/ / archivo.elcomercio.pe/mundo/actualidad/hugochavez-cumplio-11-anos-poder-se-quiere-quedar-otros-11mas-noticia-409175 
ENKVIST, Inger. Cuba y Fidel Castro fueron decisivos en el desarrollo del pensamiento de Vargas Llosa. Revista Hispano Cubana HC, 2003, no 17.

ESCOBAR, Arturo. Globalización, desarrollo y modernidad. Planeación, participación y desarrollo, 2002.

ETIENNE, Jules. Carlos Fuentes sobre el vanguardismo de Julio Cortázar. Disponible en: http: / / mitosyreincidencias.blogspot. com/2013 / 05 / carlos-fuentes-sobre-el-vanguardismo-de.html

FALCON, Manuel, 1993, Bay of Pigs and Cuban missile crisis: presidential decision-making and its effect on military employment during the Kennedy Administration. Leavenworth, Kansas: Tesis de Maestría en Arte y Ciencia Militar.

FELDMAN, Bob, 2008, Phillip Agee: 1A CIA y la Financiación de las ONG - El Diario Internacional. Eldiariointernacional.com. Disponible en: http://www.eldiariointernacional.com/spip. php?article1742

FLEMING, Robert. Panama Canal Review. Official Panama Canal Publication [en línea], 2018. Disponible en: https: / / www.gpo. gov/fdsys/ pkg/GOVPUB-W79-75aa53832e40e472df167aaade 17a19f/pdf/GOVPUB-W79-75aa53832e40e472df167aaade17a1 9f.pdf.

FREITAS, Manuel, 2010, Alianza energético-militar: Chávez y Putin desafían en el Patio Trasero. IAR Noticias [online]. Disponible en: http: / / www.iarnoticias.com/2010/secciones / latinoamerica /0020_alianza_putin_chavez_03abr2010.html

FREUD, Sigmund. Civilization and its discontents. London: W.W. Norton \& Company, Inc., 1989. 
GALEANO, Eduardo. Las venas abiertas de América Latina. Siglo XXI, 2004, p. 5.

GARCÍA FERREIRA, Roberto, 2006, La CIA y el exilio de Jacobo Árbenz. Perfiles Latinoamericanos [online]. 2006. Vol. 28, p. 59-82. Disponible en: http: / / www.scielo.org.mx/pdf/perlat/ v13n28/v13n28a3.pdf

GARCÍA, Roberto y VALLARINO, Janette, 2016, 'Estos no son cohetes': el asesinato del Presidente Remón Cantera y el lugar de Panamá en la ruta de las drogas heroicas. Revista Humanismo y Cambio Social. 2016. Vol. 3, no. 7, p. 108-132.

GONZALES ARANA, Roberto, 2009, Nicaragua, dictadura y revolución. Memorias Revista Digital de Historia y Arquieología desde el Caribe [online]. 2009. No. 10, p. 231-264. Disponible en: https: / / www.redalyc.org / articulo.oa?id=85511597009

GUEVARA, Ernesto, 2007, Carta de despedida del Che a Fidel. Profesionalespcm.org: disponible en: http://www. profesionalespcm.org/conv/0710_Getafe_Actos_CHE_ PROGRAMA.pdf

GUEVARA, Ernesto, 2008, Che Guevara, Imperialism speech 1965, translated. YouTube [online]. 2008. Disponible en: http:// www.youtube.com/watch? $\mathrm{v}=$ wdo6FwAPyng

GUEVARA, Ernesto. Che Guevara, Imperialism speech 1965, translated. Disponible en: http://www.youtube.com/ watch? $\mathrm{v}=$ wdo6FwAPyng

HERNANDO, Esther. Hannah Arendt y la cuestión de la banalidad del mal. Universidad de Cantabria, 2016. 
INMAN, Samuel Guy, 1921, The Monroe Doctrine and Hispanic America. The Hispanic American Historical Review. 1921. Vol. 4, no. 4, p. 646. DOI $10.2307 / 2505682$.

JOFRÉ, Alejandro. Fidel Castro y Gabriel García Márquez: historia de una amistad. La Tercera [en línea]. 27 de noviembre de 2016. Disponible en: http://www.latercera.com/noticia/ fidel-castro-gabriel-garcia-marquez-historia-una-amistad /

JOLLY, Richard, 2019, Education: the pre-revolutionary background. En: Cuba: the economic and social revolution. Chapel Hill: University of North Carolina Press.

KANT, Immanuel. La religión de los límites de la mera razón. Alianza Editorial, Madrid, 1985, pp. 45-48.

KORDA, Alberto. El Fotógrafo del Che. Taringa [en línea]. Disponible en: http: / / www.taringa.net/ posts / offtopic/14527976/Elfotografo-del-Che.html

KORRY, Edward, 2007, Lo que dijo Nixon sobre Allende. Disponible en: https: / / www.youtube.com/ watch?v=hQvAVXKNrPA

LA DOCTRINA BETANCOURT: ANÁLISIS Y TEXTOS FUNDAMENTALES, 2016. Democracia Participativa [online]. Disponible en: https://democraciaparticipativa. net/ documentos-data-a-referenda/documentos-en-espanol/ instrumentos-internacionales-y-declaraciones / 9548-ladoctrina-betancourt-análisis-y-textos-fundamentales.html

LAKOFF, George. Don't think of an elephant!. White River Junction: Chelsea Green Pub. Co, 2004, p. 71. ISBN: 1-931498-71-7. Traducción hecha por el autor. 
LANDMEIER, P., 1997, Banana republic: The United Fruit Company. Maya Paradise [online]. 1997. Disponible en: http:// rozylowicz.com/pdf-files/banana-republic.pdf

LARRAIIN PARADA, Javier. La izquierda revolucionaria en Chile. En: RODAS, Germán. Cuba y Latinoamérica en los años 60. Quito: Ediciones La Tierra, 2009, p. 77.

LAWRENCE, Davidson, 2005, Christian Zionism as a Representation of American Manifest Destiny. Critique: Critical Middle Eastern Studies. 2005. Vol. 14, no. 2.

LOCKHART, James, 2016, Spy vs Spy: The Bay of Pigs and the battle for the soul of the CIA. War on the Rocks [online]. Disponible en: https: / / warontherocks.com/2016/12/spy-vs-spy-thebay-of-pigs-and-the-battle-for-the-soul-of-the-cia /

MANJARREZ, Héctor. La revolución y el escritor según Cortázar. Cuadernos Políticos, 1984, no 41, p. 91.

MAO, Tse-Tung, 1967, Chairman Mao on Education Revolution. Beijing: People’s Publisher, p. 11.

MONDOLFI, EDGARDO, 2016, El día del atentado. El frustrado magnicidio contra Rómulo Betancourt. Editorial Alfa.

MONTANER, Carlos Alberto, 2015, Obama y los Castro. El País [online]. 2015. Columnistas. Disponible en: https:// www.elpaís.com.uy / opinion / columnistas / carlos-albertomontaner/obama-castro.html

MORALES, Isabel, 22 de julio de 2010, Colombia denuncia ante OEA que 1,500 guerrilleros se refugian en Venezuela. Nuevo Herald [online]. Disponible en: https://www.elnuevoherald. 
com / noticias / mundo / america-latina / venezuela-es / article2006989.html

MUELA MORILLO, Javier. En: The Social Science Post. América para los americanos: la Doctrina Monroe y la Política de EE.UU en Latinoamérica. 17 de mayo 2018. Disponible en: http: / / thesocialsciencepost.com / es / 2015/04/ america-paralos-americanos-la-doctrina-monroe-y-la-politica-de-ee-uu-enlatinoamerica /

NIXON, Richard, 1958, Minutes of National Security Council Meeting. Archivo impreso: FRUS 1958-1960, p. 240.

NIXON, Richard, 1969, Nixon Doctrine. Washington: U.S. Government.

PRESIDENCIA DE LA REPÚBLICA DE ECUADOR, 1999, Convenio de la Base de Manta. Sedici.unlp.edu.ar. Disponible en: http://sedici.unlp.edu.ar/bitstream/ handle/10915 / 46431 / Ecuador_-_Convenio_de_la_base_de_ Manta__7_p._.pdf?sequence $=2$

RAWLS, John. Teoría de la justicia. Fondo de cultura económica, 2012.

RODAS, German. La Argentina en la Segunda Posguerra y la Revolución Cubana. La década de 1960. En: RODAS, Germán. Cuba y Latinoamérica en los años 60. Quito: Ediciones La Tierra, 2009.

RODRÍGUEZ, Jorge, 2001, Cuba y la eterna Guerra Fría. Foreign Affairs en Español [online]. Vol. 1, no. 3, p. 30. Disponible en: http: / / www.people.fas.harvard.edu/ jidoming/images/jid_ cuba.PDF 
ROLDÓS BUCARAM, Martha, 2012, Actualidad y Vigencia de La Carta de Conducta. Guayaquil: Universidad de Guayaquil.

ROOSEVELT, Theodore, 1905, Corollary to the Monroe Doctrine, 1904. Annual Message to the United States Congress.

ROOT, Elihu. The Real Monroe Doctrine. The American Journal of International Law, 1914, vol. 8, no 3, p. 427. DOI: $10.2307 / 2187489$.

RUMMEL, R. J., 1991, China's Bloody Century. New Brunswick, N.J.: Transaction Publishers.

SABET, Shayda, 2019, US Foreign Policy in Latin America. E-International Relations Students [online]. 2019. Disponible en: https: / /www.e-ir.info/2013/06/14/us-foreign-policy-inlatin-america /

SANDINO, Augusto, 1927, Circular a las autoridades locales de todos los departamentos. Patria grande. Yali, Nicaragua, 1927.

SARMIENTO, Manolo and RIVERA, Lisandra, 2013, La muerte de Jaime Roldós. [film]. Quito: La Maquinita, 2013.

SCHOULTZ, Lars. Beneath the United States: a history of US policy toward Latin America. Cambridge: Harvard University Press, 1998, p. 316. Traducción hecha por el autor.

SILOCKA, R. Empire Beyond the Seas. Teachers.yale.edu [en línea], 1978. Disponible en: http://teachers.yale.edu/curriculum/ search/viewer.php?id=new_haven_78.03.07_u\&skin=h-print

SKLAR, Barry y HAGEN, Virginia. Caracas Declaration of Solidarity; March 28, 1954. U.S. Govt. Print. Off. Washington: Inter-American relations; collection of documents, legislation, 
descriptions of inter-American organizations, and other material pertaining to inter-American affairs, 1972.

SOLER SERRANO, Joaquim. Julio Cortázar en A Fondo (1977). Disponible en: http:/ / www.rtve.es/alacarta/videos/afondo/entrevista-julio-cortazar-programa-fondo/1051583/

STUMPF, Samuel y FIESER, James. Philosophy History and Problems. $6^{\text {a }}$ ed. New York: McGraw-Hill, 2003, p. 363. ISBN: 0-07-240635-6.

TÉLAM S.E. AGENCIA NACIONAL DE NOTICIAS, 2013, Un documental indaga en la muerte del ex presidente Roldós y la vincula con la dictadura en la Argentina. [online]. 2013. Internacional. Disponible en: http://www.telam.com.ar/ notas / 201308/30023-un-documental-indaga-en-la-muertedel-ex-presidente-roldos-y-la-vincula-con-la-dictadura-en-laargentina.html

TORRES, José Antonio. La historia de una foto convertida en ícono. El Nacional [en línea]. 10 de octubre de 2009. Disponible en: http: / / elnacional.com.do/la-historia-de-una-foto-convertidaen-icono/

TROTSKY, León. Literatura y revolución. Ediciones digitales Izquierda Revolucionaria, 2006.

TWAIN, Mark, 1901, To the person sitting in darkness. AntiImperialist League of New York: New York.

UNITED FRUIT COMPANY, web.mit.edu [online], 2018.Disponible en: http: / / web.mit.edu/course/21/21f704/UnitedFruit/ UnitedFruit.html 
VALENCIA GRAJALES, José y MARÍN GALEANO, Mayda, 2016, Elementos que describen una dictadura en América Latina. Investigación. 2016. Vol. 8, no. 1, p. 43-56.

VÁSQUEZ, Jorge Daniel, 2018, Sobre la cuestión de la memoria en Ecuador. La muerte de Jaime Roldós ante la prevención historiográfica. Fuerza de Campo. 2018. Vol. 2, no. 1, p. 88-103.

VIGUERA, Aníbal. Movimientos Sociales y Lucha de Clases. Conflicto Social, 2009, vol 2, no. 1, p. 7. ISSN: 1852-2262.

WALTER, MARTIN, 2006, Extractives in Latin America and the Caribbean. Inter-American development Bank. Disponible en: https://publications.iadb.org/publications/english/ document/ Extractives-in-Latin-America-and-the-CaribbeanThe-Basics.pdf

WELLS, Milton. Communism in Guatemala: The Department's request for a report is Lovett to U.S. Embassy Guatemala, 1948.

WILLIAMS, Charles Richard. Diary and letters of Rutherford Birchard Hayes. Columbus: Ohio State Archaeological and Historial Society, 1922, pp. 583-589. 


\section{Autores:}

\section{Dr. Christian Naranjo}

Conferenciante internacional en temas relacionados con las ciencias políticas, historia económica, filosofía política y cristianismo. Sus artículos han sido publicados en Journal of Iberian and Latin American Economic History, Journal of Evolutionary Studies in Business, Revista Historia Autónoma, Cuadernos de Teología, etc. Miembro de la Asociación Ecuatoriana de Historia Económica y

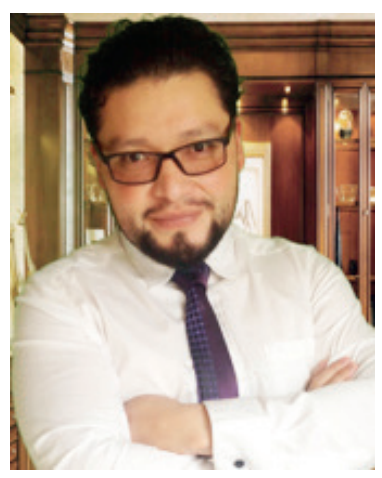
docente investigador en la Universidad Nacional de Chimborazo.

\section{Dra. Cumandá Navas}

Escritora e investigadora en educación, políticas públicas y filosofía. Sus escritos han sido publicados en Multidisciplinary Journal for Education, Social and Technological Science, IUSTA Revista de Ciencias Políticas, y Chañinan Revista de Ciencias Sociales y Humanidades. Docente de la Universidad Nacional de Chimborazo.

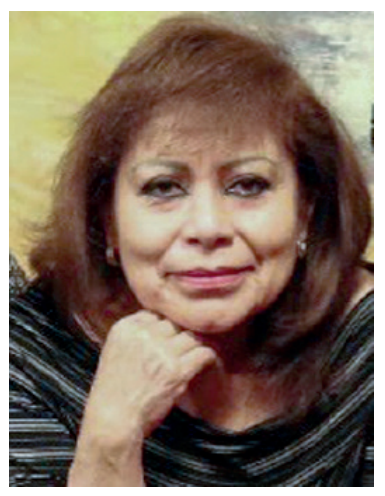




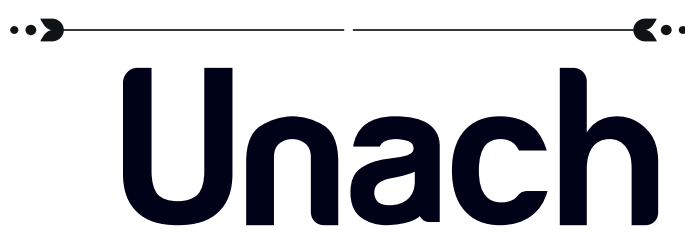

UNIVERSIDAD NACIONAL DE CHIMBORAZO

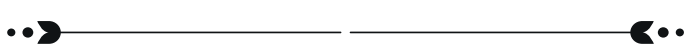

Gestión del Conocimiento y Propiedad Intelectual

ROMANTICISMO Y REVOLUCIÓN EN LATINOAMÉRICA; se publicó en el mes de septiembre de 2020 en la Universidad Nacional de Chimborazo. 


\section{20 Romanticismo y Revolución en Latinoamérica}

América Latina ha vivido procesos políticos intricados entre la influencia de occidente, con su pasión que abraza el liberalismo y protege a su hija predilecta, la democracia, y la influencia de las ideas de revolución emergentes desde el dominio marxista. Esta puja por una región inestable se encarna a partir del nacimiento de las repúblicas latinoamericanas en dos clanes: por un lado, un gran líder mundial, el hegemón, el llamado a personificar las estructuras de moralidad vista desde el orden y la reprensión; por otro lado, los movimientos revolucionarios que encarnan la sublevación a las ideas de occidente, la insurrección al capitalismo y el liberalismo, y a favor de la imposición de sistemas políticos que rayan con el marxismo: la eliminación de clases sociales, de la propiedad privada, de la libertad de prensa y opinión. Por un lado, en el contexto de occidente, el individuo sobresale sobre el comunitarismo y corporativismo; por otro lado, la idea de colectivo, representado en un gobierno, sobrepasa al individuo y a sus derechos.

Durante el reinado de Luis XIV (1643-1715), Francia se hallaba bajo el dominio de una monarquía absolutista, el poder de rey y de la nobleza eran la base de este régimen. El estado se encontraba en una situación económica bastante precaria, que se agravó por el mal gobierno de Luis XV (bisnieto de Luis XIV), y tocó fondo durante el reinado de Luis XVI, gobernante bien intencionado, pero de carácter débil, por lo que se lo llamaba el buen Luis. Las crisis de las monarquías francesas condujeron la nación a la Revolución Francesa, guiada por tres principios: libertad, igualdad y fraternidad. El ejemplo francés pretendería afirmar que la libertad es la piedra angular de toda revolución, pero la historia nos deja saber que la libertad, a veces, es aparejada con el capitalismo y, en su defecto, con la democracia. Las crisis han llevado a las naciones en pensar en subversiones que cambien el sistemas político, económico y social, pero la subversión no necesariamente comprende la inclusión de la libertad como eje conductor, sino que puede incluir la eliminación de la libertad y su reemplazo por la fidelidad al revolucionario y a sus ideales.
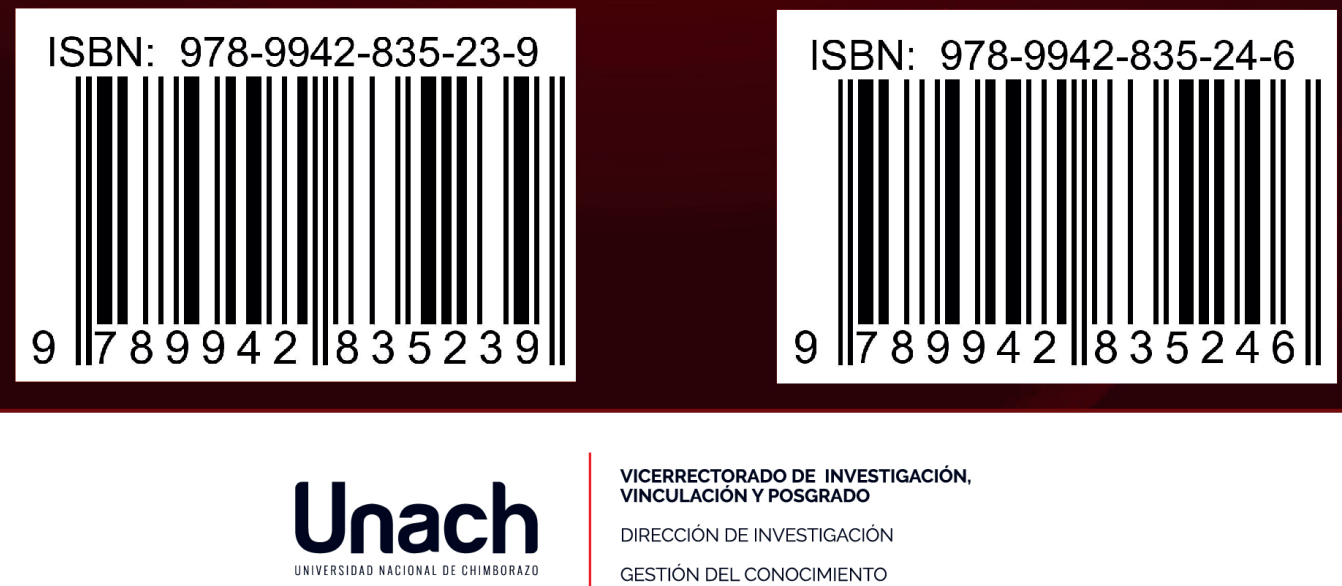

VICERRECTORADO DE INVESTIGACIÓN,

VINCULACIÓN Y POSGRADO

DIRECCIÓN DE INVESTIGACIÓN

GESTIÓN DEL CONOCIMIENTO

Y PROPIEDAD INTELECTUAL 